\title{
Morphology and Taxonomy of Isopoda Anthuroidea (Crustacea) from Sulawesi with description of six new species
}

\author{
Manikmayang ANNISAQOIS ${ }^{1} \&$ J. Wolfgang WÄGELE ${ }^{2, *}$ \\ ${ }^{1}$ Faculty of Fisheries and Marine Sciences, Sam Ratulangi University, \\ Jln Kampus UNSRAT - Bahu, Manado 95115, Indonesia. \\ ${ }^{2}$ Zoological Research Museum Alexander Koenig, Adenauerallee 160, 53113 Bonn, Germany. \\ *Corresponding author: w.waegele@leibniz-zfmk.de \\ ${ }^{1}$ Email address: manikmayangannisa@gmail.com \\ ${ }^{1}$ urn:1sid:zoobank.org:author:87AF69D7-A157-4C75-928E-77914A99E7AA \\ ${ }^{2}$ urn:lsid:zoobank.org:author:B6956EF7-CC6D-4C0F-8678-CCAB27250A5E
}

\begin{abstract}
This is a first inventory of Isopoda Anthuroidea from near-shore marine sites in Sulawesi. The material was collected from reefs, sea-grass beds and mangroves of the Minahasa Peninsula in North Sulawesi. Specimens were washed out from benthos samples collected in shallow water. The new species Hyssura reptans sp. nov., Kupellonura indonesica sp. nov., Kupellonura macaroni sp. nov., Pendanthura bangkaensis sp. nov., Expanathura marcoi sp. nov., and Colanthura gerungi sp. nov. are described. We discovered that in Colanthura the mandible is fused to the cephalothorax, a unique feature among isopods. Expanathura collaris (Kensley, 1979) is described from Bangka Island and several differences between other Indo-Pacific populations are discussed.
\end{abstract}

Keywords. Coral reef fauna, Hyssuridae, Anthuridae, Expanathuridae, Paranthuridae, new species.

Annisaqois M. \& Wägele W.J. 2021. Morphology and Taxonomy of Isopoda Anthuroidea (Crustacea) from Sulawesi with description of six new species. European Journal of Taxonomy 768: 1-52.

https://doi.org/10.5852/ejt.2021.768.1501

\section{Introduction}

During field trips to Bangka Island with students from the University Sam Ratulangi (UNSRAT) in Manado (Sulawesi), we started to separate invertebrates for the UNSRAT collection. Nearly all collected specimens still await identification.

Samples of near-shore benthos in coral reef and mangrove areas contained a large number of small crustaceans, among them several isopod species. Since the Indonesian fauna is poorly studied, we expect to see in the future many descriptions of new species from this region of the Coral Triangle. We focus here on Anthuroidea Leach, 1914. The remaining material has to be studied in the coming years. 
Anthuroidea have a world-wide distribution. Species occur from polar to tropical marine waters, some live in freshwater and in estuaries, others in the deep sea (Negoescu \& Wägele 1984). However, little is known about the coral reef fauna of Indonesia.

In 2013, Conni M. Sidabalok published a first check-list of the Isopoda then known from Indonesia. There are 17 anthuroid species described from different islands since 1900, with one exception (Pseudanthura albatrossae Kensley, 1978c) all from shallow near-shore and sublittoral habitats. A more thorough search for species at a single locality has never been ventured. From Sulawesi, the four species Apanthura indonesiensis Negoescu, 1997 (from Bunaken Island), Colanthura kensleyi Poore, 1984 (reported from Sangihe Islands, but also from the Philippines), Paranthura bunakensis Negoescu, 1997 (from Bunaken Island), and Pseudanthura albatrossae Kensley, 1987 (from a bathyal locality of the Gulf of Boni in South Sulawesi) have been described. Pendanthura sp. (described but not named by Negoescu 1997), also listed by Sidabalok for Sulawesi, was only found in Kalimantan. Due to the very high diversity of other coral reef taxa (e.g., Edinger et al. 2000, Eisenbarth et al. 2018, Yalindua et al. 2021) in the Coral Triangle area it must be suspected that the majority of small reef crustaceans still has to be discovered.

\section{Material and methods}

The material presented herein was collected during field trips with participants of the Sam Ratulangi University in Manado (Indonesia) and the Zoological Research Museum Alexander Koenig in Bonn (Germany). Near-shore benthic material was collected by SCUBA diving or snorkeling, collecting coral rubble in buckets, brushing the epifauna of mangrove roots into small nets, or using a small dredge from a boat to collect in seagrass or mangrove channels. After washing the samples and collecting the material from wash water in $0.2 \mathrm{~mm}$ sieves, specimens were sorted alive in the laboratory of the Coral Eye resort on Bangka Island using a Zeiss stereo microscope Stemi 508. Specimens were fixed in $80 \%$ ethanol. Pencil drawings of whole specimens and dissected parts were prepared with an Olympus BX41 microscope equipped with a camera lucida. Drawings were later inked, scanned, and arranged with Adobe Photoshop CS5.

All samples were taken in shallow water ( $0-5 \mathrm{~m}$ depth). Among small crustaceans, isopods proved to be much less abundant in samples than Tanaidacea Hansen, 1895 or Amphipoda Latreille, 1816. We focus here on anthurids, of which we found only a few specimens per species. There are certainly more species in these reef habitats than described herein. In the future, we will complete the species inventory with material from new expeditions and from existing collections.

All type material is deposited in the Museum Zoologicum Bogoriense (MZB), Bogor, Java / Indonesia. Permits for deposition of specimens in collections abroad or for genetic work were not available.

\section{Abbreviations used in text and figures}

$\begin{array}{ll}\text { A1 } & =\text { antenna 1 } \\ \mathrm{A} 2 & =\text { antenna } 2 \\ \mathrm{Md} & =\text { mandible } \\ \mathrm{Mx} & =\text { maxilla 1 } \\ \mathrm{Mxp} & =\text { maxilliped } \\ \mathrm{P} 1-7 & =\text { pereopod 1-7 } \\ \text { Plp 1-5 } & =\text { pleopod 1-5 } \\ \text { Uex } & =\text { uropod exopod } \\ \text { Uen } & =\text { uropod endopod } \\ \text { Urp } & =\text { uropod } \\ \mathrm{Tel} & =\text { telson }\end{array}$




\section{Results}

Table 1 lists only the anthurid specimens collected on Bangka Island in the field campaign of 2019. A map with sampling locations is shown in Figure 1.

\section{Taxonomy}

Order Isopoda Latreille, 1817

Suborder Cymothoida Wägele, 1989

Superfamily Anthuroidea Leach, 1914

Family Hyssuridae Wägele, 1981

Genus Hyssura Norman \& Stebbing, 1886

\section{Type species}

Hyssura producta Norman \& Stebbing, 1886. This genus currently comprises six species, we add a seventh one, the first known from the Indo-Pacific Ocean. All hitherto known species occur in deeper water, the shallowest record was until now H. bacescui (George \& Negoescu, 1982) from $37 \mathrm{~m}$ depth off the coast of Alabama. We present here a first species found in coral reefs.

\section{Hyssura reptans sp. nov. urn:Isid:zoobank.org:act:D0451121-5E07-4F60-BADC-85D3D8BA38E9}

Figs 2-5

\section{Differential diagnosis}

Blind species of Hyssura (eyes also lacking in male), pereopod 1 propodus palm concave in male, a comb of 6 setae on mesial surface in addition to two stronger medial setae and distally 4 setae, pleopod rami rectangular, pleopod 1 exopod not larger than endopod; exopods of pleopods 1 and 2 distally with more, 10 resp. 9 swimming setae, endopods with 5, uropod exopod narrow lanceolate, outer lateral margin smooth, medial margin slightly serrated, apex with several long simple setae, endopod of uropod as wide as sympod but about 2.5 times longer, a bit shorter than exopod, proximal two thirds of margins nearly parallel, distal margins with simple setae of varying length. Telson tongue-like, lateral margins serrated, not parallel; apex rounded and with 5 pairs of simple setae.

Hyssura ligurica Wägele, 1981 (see Wägele 1981a) is most similar, with a tail fan that resembles that of $H$. reptans sp. nov. Hyssura ligurica also has rectangular pleopod rami, but in comparison with H. reptans longer meri and carpi in P4-7 and only one sensory spine on the propodi. The female has strong propodi of $\mathrm{P} 1$ and $\mathrm{P} 2$; unfortunately, the females of $H$. reptans still remain to be discovered.

\section{Etymology}

The species epithet is derived from repto (to crawl).

\section{Material examined}

\section{Holotype and type locality}

INDONESIA • ô (2.1 mm); Bangka Island, off Areng Kambing; $1^{\circ} 46^{\prime} 27.53^{\prime \prime} \mathrm{N}, 125^{\circ} 11^{\prime} 19.53^{\prime \prime} \mathrm{E} ; 5 \mathrm{~m}$ depth; in coral rubble; M. Annisaqois and J.W. Wägele leg.; Sep. 2019; MZB Iso 099.

\section{Description of type specimen}

Boby. Without chromatophores, 15-16 times as long as wide (rostrum to tip of telson). Head 1.7 times as long as wide, with a lateral constriction at half of its length. Eyes lacking. A small rostral 
Table 1. Anthuridea collected on the shores of Bangka Island.

\begin{tabular}{|c|c|c|c|c|c|}
\hline Species name & Sample locality & Substrate & Depth & Date & $\begin{array}{l}\text { Collected } \\
\text { specimen }\end{array}$ \\
\hline $\begin{array}{l}\text { Hyssura reptans sp. } \\
\text { nov. }\end{array}$ & $\begin{array}{l}\text { Bangka Island, off Areng Kambing, } \\
1^{\circ} 46^{\prime} 27.53^{\prime \prime} \mathrm{N}, 125^{\circ} 11^{\prime} 19.53^{\prime \prime} \mathrm{E}\end{array}$ & Coral rubble & $5 \mathrm{~m}$ & 24 Sept. 2019 & 1 \\
\hline $\begin{array}{l}\text { Kupellonura } \\
\text { indonesica sp. nov. }\end{array}$ & $\begin{array}{l}\text { Bangka Island, off jetty of Coral } \\
\text { Eye resort, } \\
1^{\circ} 44^{\prime} 22.04^{\prime \prime} \mathrm{N}, 125^{\circ} 8^{\prime} 41.19^{\prime \prime} \mathrm{E}\end{array}$ & Coral rubble & $2 \mathrm{~m}$ & 17 Sept. 2019 & 8 \\
\hline $\begin{array}{l}\text { Kupellonura } \\
\text { maccaroni sp. nov. }\end{array}$ & $\begin{array}{l}\text { Bangka Island, off jetty of Coral } \\
\text { Eye resort, } \\
1^{\circ} 44^{\prime} 22.04^{\prime \prime} \mathrm{N}, 125^{\circ} 8^{\prime} 41.19^{\prime \prime} \mathrm{E}\end{array}$ & Coral rubble & $2 \mathrm{~m}$ & 17 Sept. 2019 & 2 \\
\hline $\begin{array}{l}\text { Pendanthura } \\
\text { bangkaensis sp. nov. }\end{array}$ & $\begin{array}{l}\text { Bangka Island, off Coral Eye } \\
\text { Resort, } \\
1^{\circ} 44^{\prime} 22.04^{\prime \prime} \mathrm{N}, 125^{\circ} 8^{\prime} 41.19^{\prime \prime} \mathrm{E}\end{array}$ & Coral rubble & $1-2 \mathrm{~m}$ & 21 Sept. 2019 & 3 \\
\hline $\begin{array}{l}\text { Expanathura collaris } \\
\text { (Kensley, 1979) }\end{array}$ & $\begin{array}{l}\text { Bangka Island, in front of Coral } \\
\text { Eye Resort near jetti, } \\
1^{\circ} 44^{\prime} 20.22^{\prime \prime} \mathrm{N}, 125^{\circ} 8^{\prime} 46.07^{\prime \prime} \mathrm{E}\end{array}$ & Coral rubble & $1-2 \mathrm{~m}$ & 26 Sept. 2019 & 5 \\
\hline $\begin{array}{l}\text { Expanathura marcoi } \\
\text { sp. nov. }\end{array}$ & $\begin{array}{l}\text { Bangka Island, in front of Coral } \\
\text { Eye Resort, } \\
1^{\circ} 44^{\prime} 20.22^{\prime \prime} \mathrm{N}, 125^{\circ} 8^{\prime} 46.07^{\prime \prime} \mathrm{E}\end{array}$ & Coral rubble & $1-2 \mathrm{~m}$ & 26 Sept. 2019 & 1 \\
\hline \multirow[t]{3}{*}{$\begin{array}{l}\text { Colanthura gerungi } \\
\text { sp. nov. }\end{array}$} & $\begin{array}{l}\text { Bangka Island, west of Coral Eye } \\
\text { Resort, } \\
1^{\circ} 45^{\prime} 20.77^{\prime \prime} \mathrm{N}, 125^{\circ} 7^{\prime} 57.28^{\prime \prime} \mathrm{E}\end{array}$ & Seagrass bed & $1-2 \mathrm{~m}$ & 18 Sept. 2019 & 14 \\
\hline & $\begin{array}{l}\text { Bangka Island, west of Coral Eye } \\
\text { Resort, } \\
1^{\circ} 45^{\prime} 19.92^{\prime \prime} \mathrm{N}, 125^{\circ} 7^{\prime} 58.96^{\prime \prime} \mathrm{E}\end{array}$ & $\begin{array}{l}\text { Mangrove } \\
\text { roots }\end{array}$ & $1-2 \mathrm{~m}$ & 21.Sept. 2019 & 2 \\
\hline & $\begin{array}{l}\text { Bangka Island, off Coral Eye } \\
\text { Resort, } \\
1^{\circ} 44^{\prime} 22.04^{\prime \prime} \mathrm{N}, 125^{\circ} 8^{\prime} 41.19^{\prime \prime} \mathrm{E}\end{array}$ & Coral rubble & $1-2 m$ & 26 Sept. 2019 & 1 \\
\hline
\end{tabular}

projection between antennae. Pereonites dorsally smooth, as long as wide, length ratio of pereonites: $1<2>3<4>5>6>7$, pereonite 3 being about as long as pereonite 7 . Pleonites $1-5$ free, as wide as pereonites, total length of pleonites $1-5$ exceeds length of pereonites $6+7$. Telson about as long as uropods and shorter than three pleonites.

Antennae. Antenna 1 peduncle of three articles, first 1.5 times as long as wide, articles 2 and 3 progressively shorter; flagellum with typical male modifications: nearly twice as long as peduncle and composed of 9 articles; distal articles narrower, last article tiny; all flagellum articles except the first with long and thin aesthetascs, arranged in a single transverse row per article, number of aesthetascs distally decreasing, last article with only one aesthetasc. Antenna 2 peduncle with 5 articles, second article longest and widest; flagellum of 8 articles, not as long as peduncle articles $4+5$, with several simple setae, longest on distal article.

MouthParts. Were lost during dissection; however, in situ a maxilliped palp with five articles was visible, not covering mouthparts but erected nearly perpendicularly, and a mandible with an atrophied endite. Presumably the mouthparts of males are not functional. 
Pereopods. Pereopod 1 weakly subchelate, propodus palm concave, a comb of 6 setae on mesial surface in addition to two stronger medial setae and distally 4 setae; carpus triangular with short, not prominent ventrodistal projection bearing a simple seta; more proximally another seta; merus dorsal portion nearly triangular. Pereopod 2 propodus less curved than in P1, elongated, about three times as long as wide, palm distally with 3 sensory spines and basally slightly concave; carpus ventrodistally only little projecting, as in pereopod 1. Pereopod 3 similar to pereopod 2. Pereopods 4-7 similar. Propodi distally with two short sensory spines on distoventral margin, with a tooth-like projection in between, carpus trapezoidal, with shorter dorsal margin, merus subtriangular and as long as carpus.

PLEOPODS. All of similar shape, rami nearly rectangular. Pleopod 1 exopod not larger than endopod; exopods of pleopods 1 and 2 distally with 10 resp. 9 swimming setae, endopods with 5. Exopod of Plp 2 composed of two articles. Appendix masculina on Plp2 in form of a cylindrical rod about $30 \%$ as long as endopod, distally rounded, without further conspicuous features.

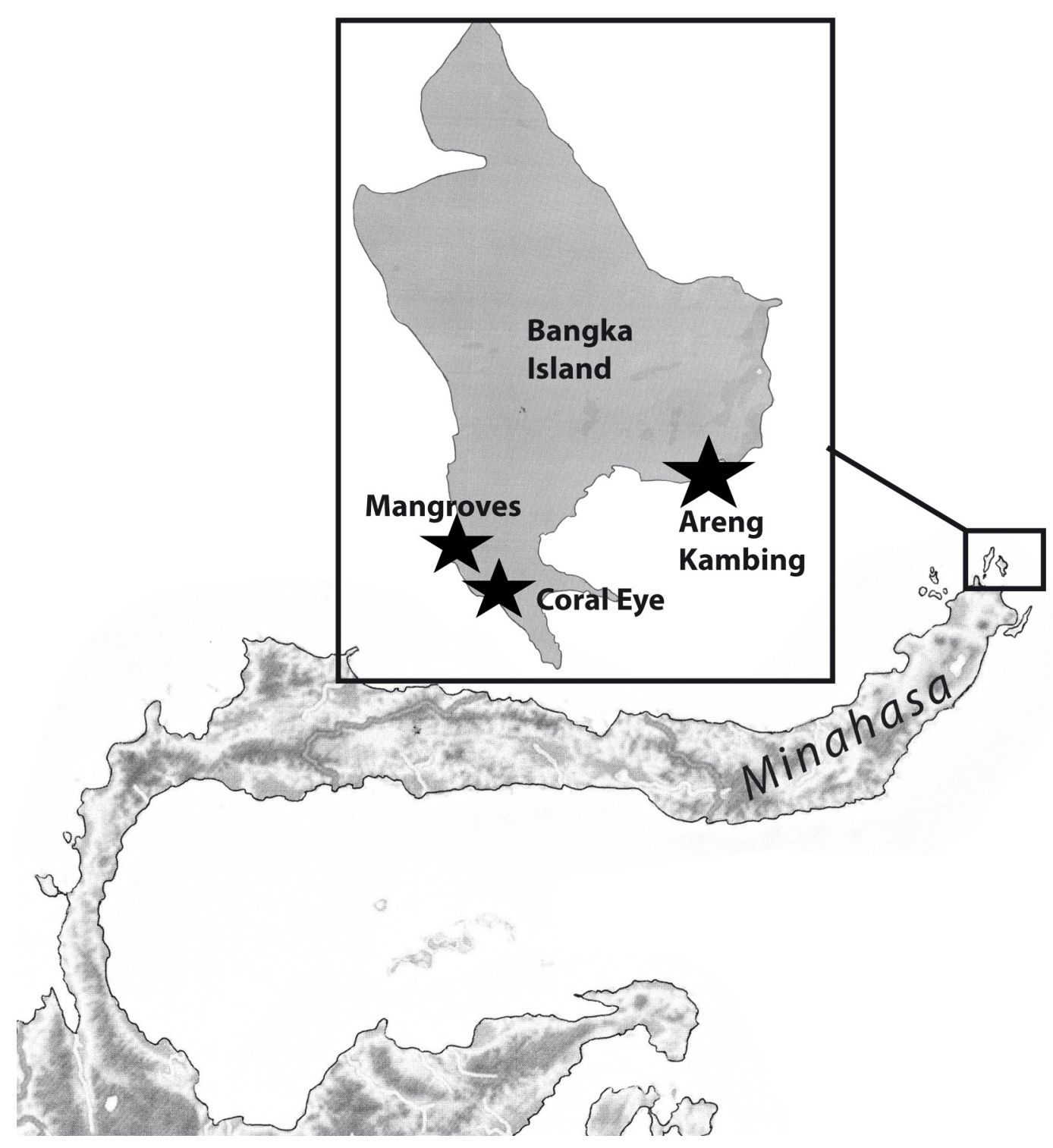

Fig. 1. Map of Northern Sulawesi with sampling sites on Bangka Island 




Fig. 2. Hyssura reptans sp. nov., $\widehat{\jmath}$, holotype in dorsal and lateral view (2.1 mm) (MZB Iso 099). 


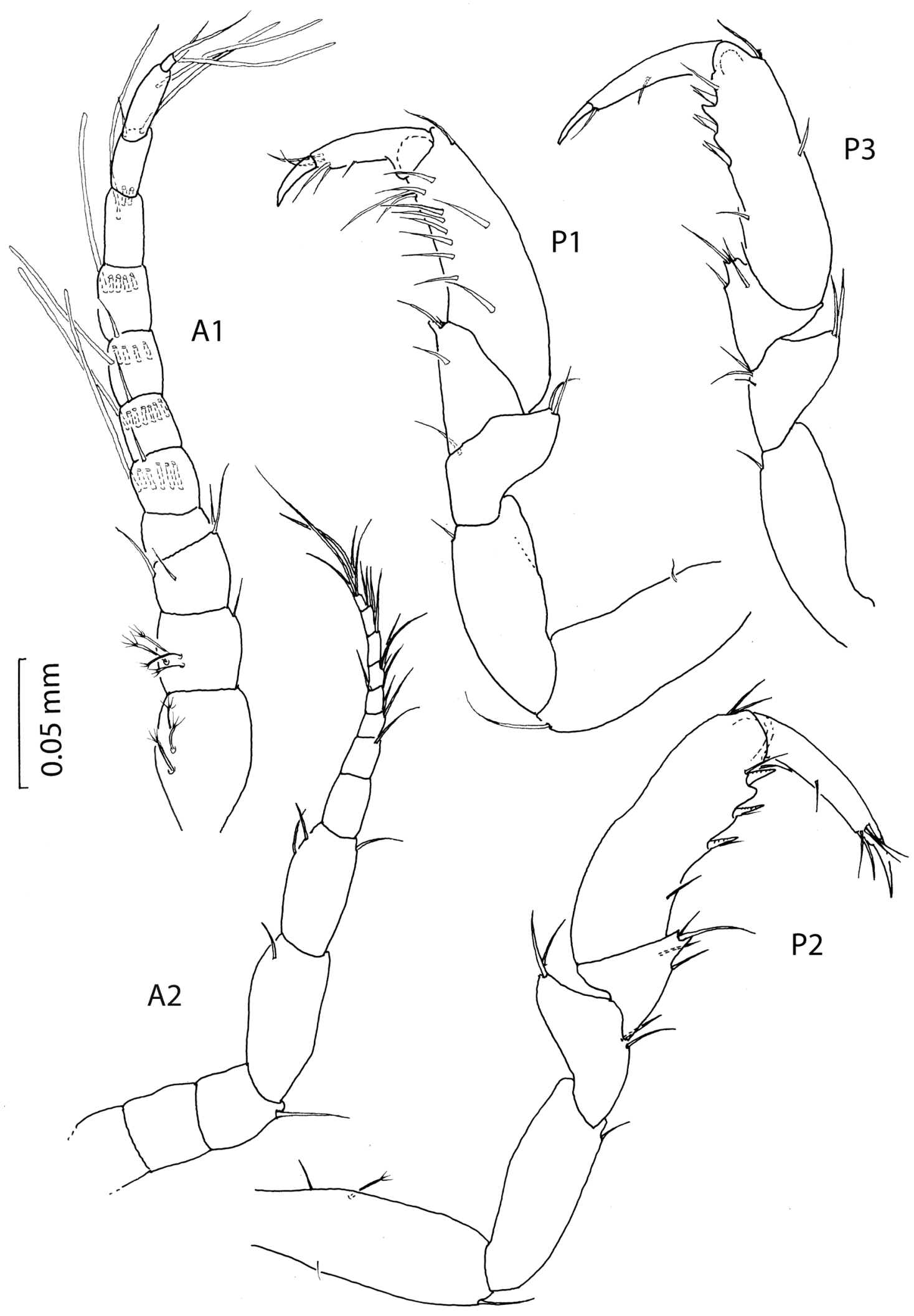

Fig. 3. Hyssura reptan sp. nov., Ô, holotype (MZB Iso 099). Abbreviations: A1 = antenna 1; A2 = antenna $2 ; \mathrm{P} 1-\mathrm{P} 3=$ pereopods $1-3$. 

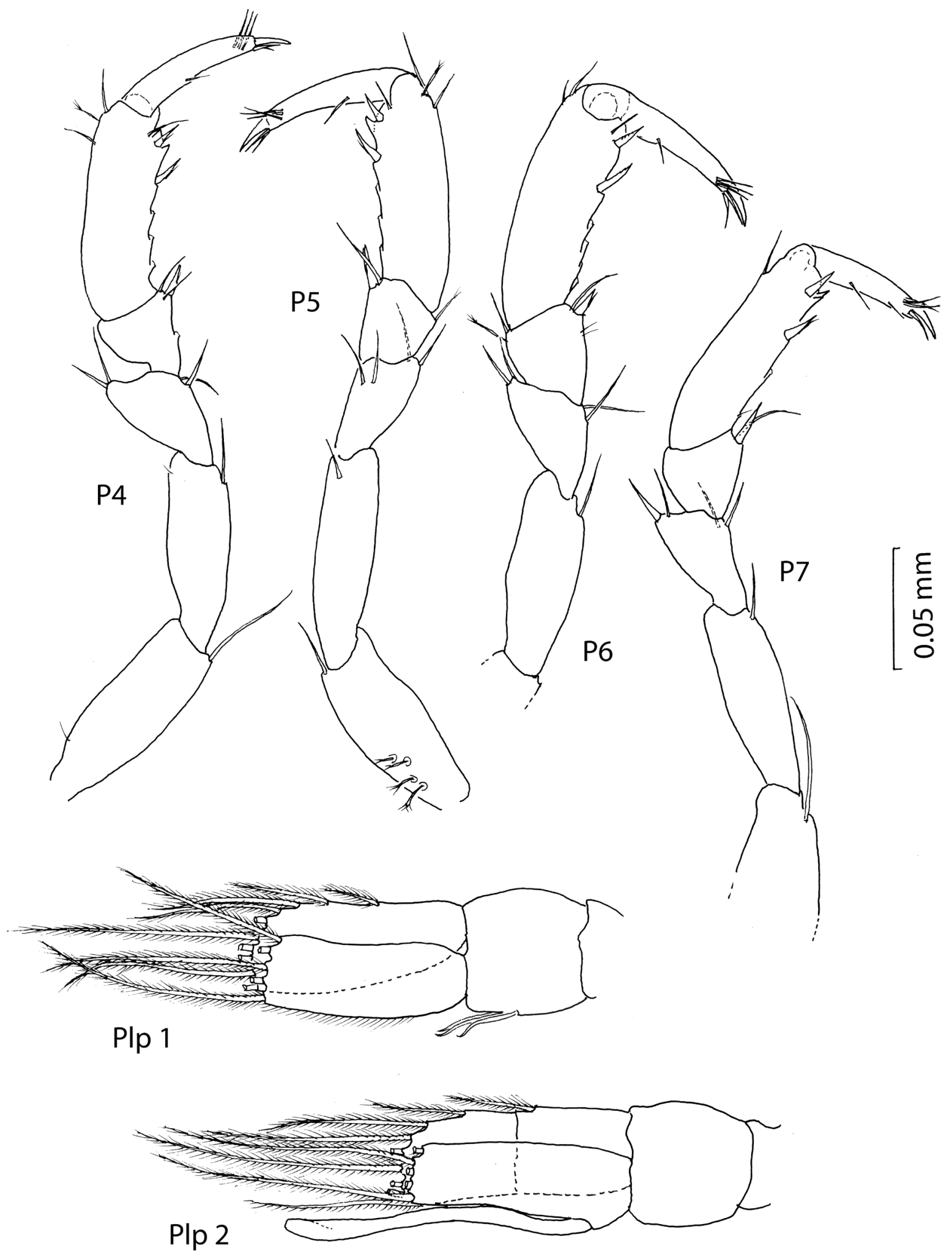

Fig. 4. Hyssura reptans sp. nov., $\widehat{\jmath}$, holotype (MZB Iso 099). Abbreviations: P4-P7 = pereopods 4-7; Plp1-2 = pleopods 1-2. 
UROPOD. Exopod narrow lanceolate, length about 7.6 times greatest width, outer lateral margin smooth, medial margin slightly serrated with some single setae in notches; apex with several long simple setae. Endopod as wide as sympod but about 2.5 times longer, a bit shorter than exopod, proximal two thirds of margins nearly parallel, distal margins with simple setae of varying length. Telson tongue-like, lateral margins serrated, not parallel; apex rounded and with 5 pairs of simple seate.

\section{Remarks}

We place this species in the genus Hyssura Norman \& Stebbing, 1884 because autapomorphies of other genera are missing. Species of Hyssura are blind, the P1-3 carpus is barely projecting ventrodistally. A reduction of male mouthparts has been reported for $H$. vimsae (Kensley, 1978a) (see Wägele 1981a), other males have not been described. The male of $H$. vimsae also has a comb of setae on P1 propodus; similar combs have also been described for some species of Kupellonura (K. biriwa, K. marrongie, see Poore \& Lew Ton 1988). It is remarkable that also the male is blind, while in other Hyssuridae at least males have prominent eyes. In the present species the carpus of P4-7 is shorter than in previously described species. Other characters are plesiomorphic and occur also in other Hyssuridae.

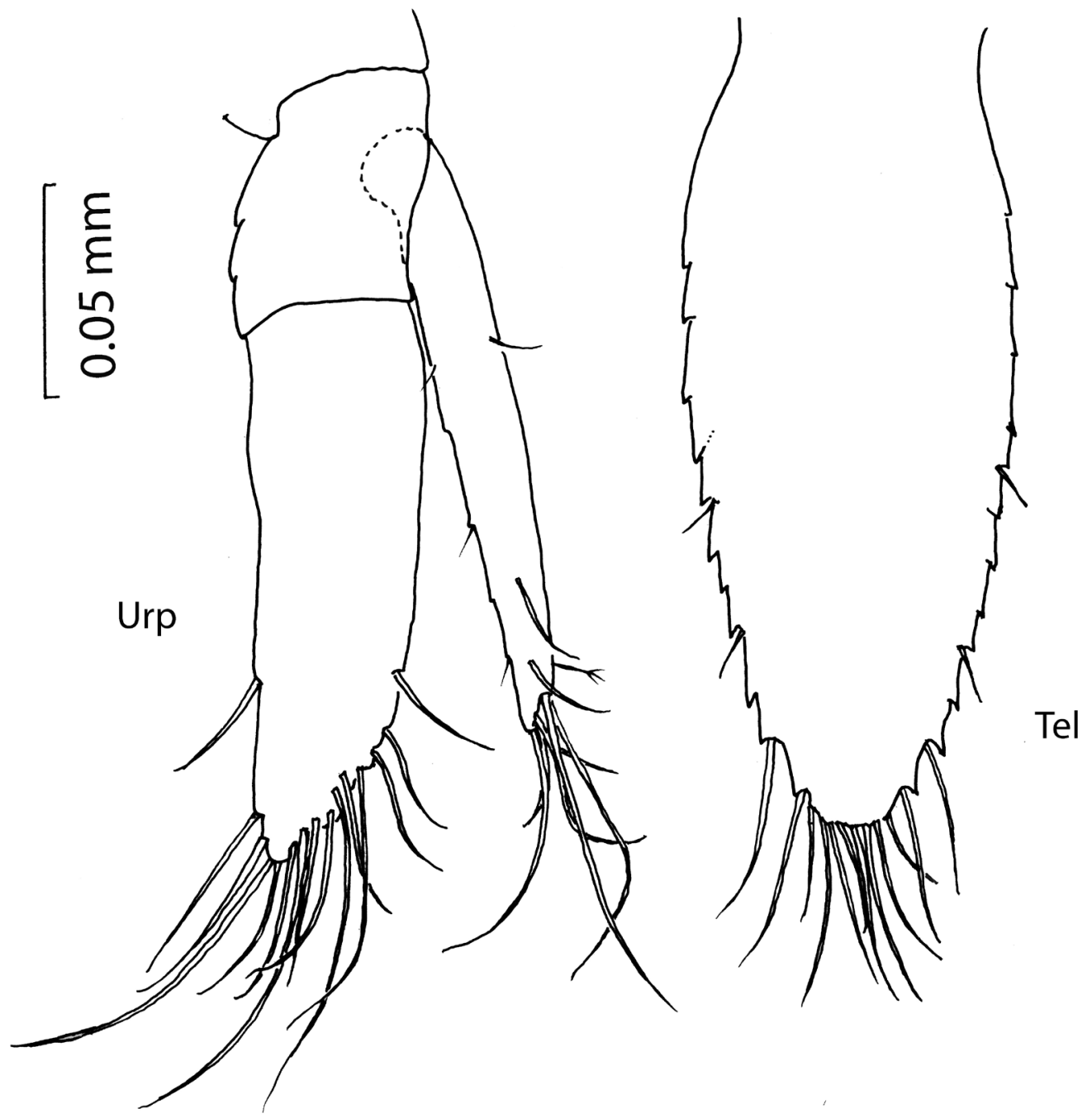

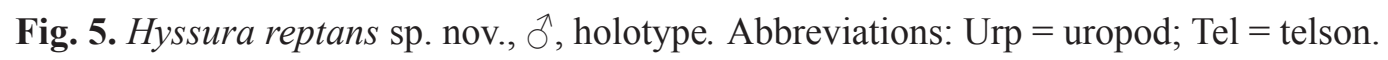


This is the first Hyssura described from the Indo-Pacific. The other species occur in the Atlantic Ocean or in the Mediterranean and often in bathyal waters

Genus Kupellonura Barnard, 1925

\section{Type species}

Kupellonura mediterranea Barnard, 1925. Until now, 16 species were known, most of them from tropical and temperate waters. They have been found in shallow habitats but also in bathyal sites (K. flexibilis (Pasternak 1982): $2890 \mathrm{~m}$ depth).

\section{Kupellonura indonesica sp. nov. urn:1sid:zoobank.org:act:C6689867-1A0D-4D40-B97F-DEF712439118}

Figs 6-9

\section{Differential diagnosis}

Kupellonura with pair of small dorsolateral black eyes, pereopod 1 propodus with two prominent strong setae on mesial surface, on palm two short sensory spines, carpus with acute posterodisal projection, pereopods 2 and 3 subsimilar to 1; however, propodus more slender, palm with 2 sensory spines and carpus projecting as in pereopod 1. Uropod exopod long-oval, greatest width proximally, lateroventral margin forming a shallow lobe; lateral margins smooth, a single short seta on each side, apex with several long simple setae; uropod endopod as long as sympod, shorter than exopod, elongated with rounded apex, telson tongue-like, lateral margins not parallel, distally on each side of apex a single prominent tooth; apex with central pair of short setae, and on each side of it another 5 setae.

Focusing on species known from the tropical/subtropical Indo-Pacific, K. afareiatu Müller, 1991 from Moorea has a broader uropod exopod and a Plp 1 endopod distinctly narrower than the exopod. It seems that on the propodus of $\mathrm{P} 1$ there is only 1 strong seta on the mesial surface. The species needs to be redescribed. K. caudoserrata Negoescu, 1994 (New Caledonia) has serrated telson margins and uropod exopod dorsomedial margins, and a longer maxilliped endite (surpassing the second palp article). K. currawan Poore \& Lew Ton, 1988 (New South Wales), K. gidgee Poore \& Lew Ton, 1988, K. marrongie Poore \& Lew Ton, 1988 and K. werawera Poore \& Lew Ton, 1988 from Queensland need redescriptions, but the tail fan drawings clearly show differences with the new species: serrated margins of uropods in K. currawan, broader uropods in K. gidgee, and slender uropod exopods without ventrolateral lobe in $K$. marrongie. In $K$. currawan the propodus palms of P1 and P2 have three (instead of two) spines. In $K$. werawera the uropod exopod lobe at its ventrolateral margin is larger than in the new species, furthermore, in $K$. werawera the lateral telson margins are parallel.

\section{Etymology}

Named after the country where the species was discovered.

\section{Material examined}

\section{Holotype}

INDONESIA - immature adult (2.5 mm); Bangka Island (Northern Sulawesi), off the jetty of Coral Eye Resort; $1^{\circ} 44^{\prime} 22.04^{\prime \prime} \mathrm{N}, 125^{\circ} 8^{\prime} 41.19^{\prime \prime} \mathrm{E} ; 2 \mathrm{~m}$ depth; in coral rubble; M. Annisaqois and J.W. Wägele leg.; 17 Sep. 2019; MZB Iso 100.

\section{Paratypes}

INDONESIA -3 immature adults $(2.5-2.8 \mathrm{~mm}), 3$ manca stages $(1.8-2.25 \mathrm{~mm}), 1$ postmanca $(2.5 \mathrm{~mm})$; Bangka Island (Northern Sulawesi), off the jetty of Coral Eye Resort; $1^{\circ} 44^{\prime} 22.04^{\prime \prime} \mathrm{N}, 125^{\circ} 8^{\prime} 41.19^{\prime \prime}$ E; $2 \mathrm{~m}$ depth; in coral rubble; M. Annisaqois and J.W. Wägele leg.; 17 Sep. 2019; MZB Iso 101. 


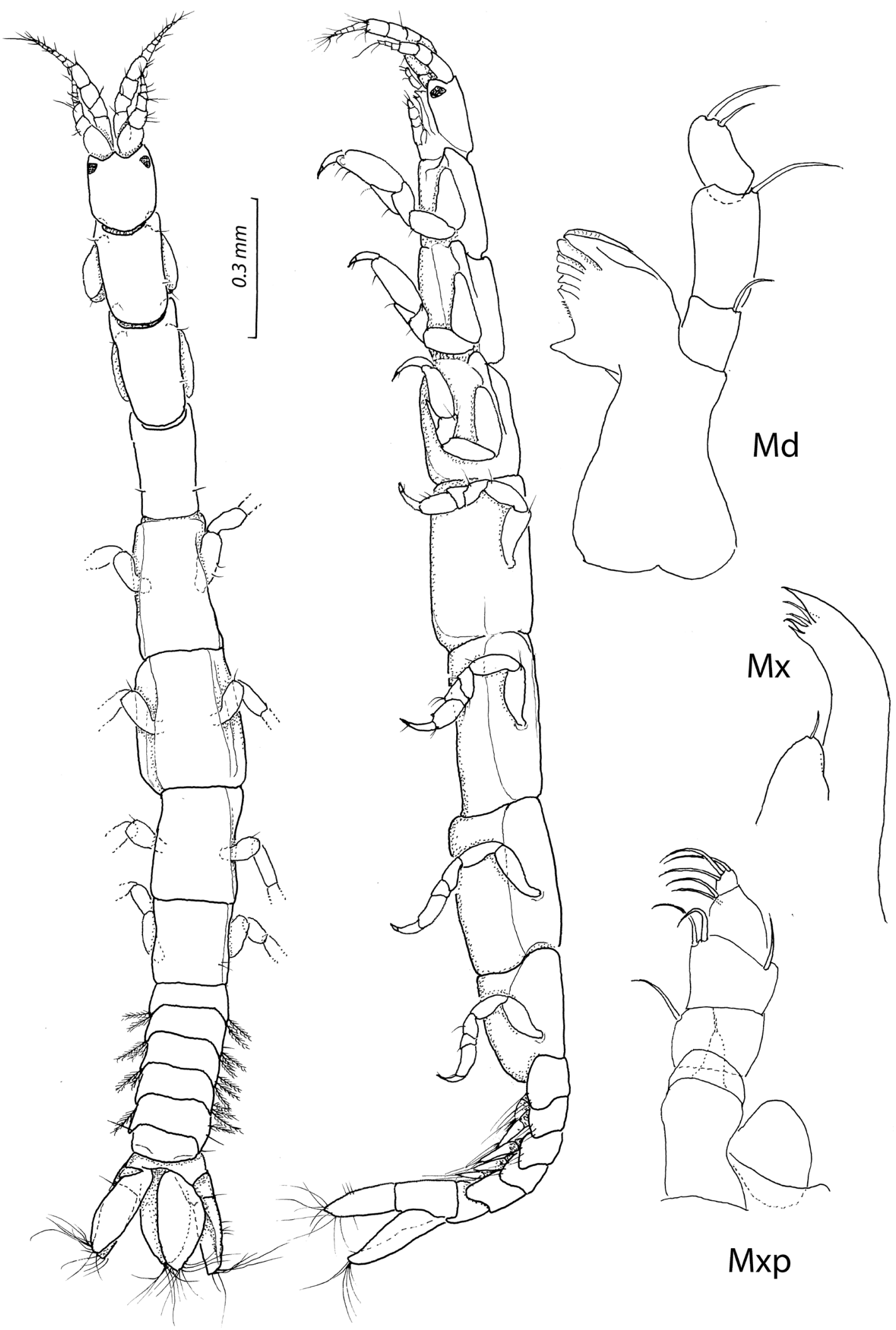

Fig. 6. Kupellonura indonesica sp. nov., holotype, immature adult in dorsal and lateral view $(2.5 \mathrm{~mm})$ (MZB Iso 100). Abbreviations: $\mathrm{Md}=$ mandible; $\mathrm{Mx}=$ maxilla; $\mathrm{Mxp}=$ maxilliped. 

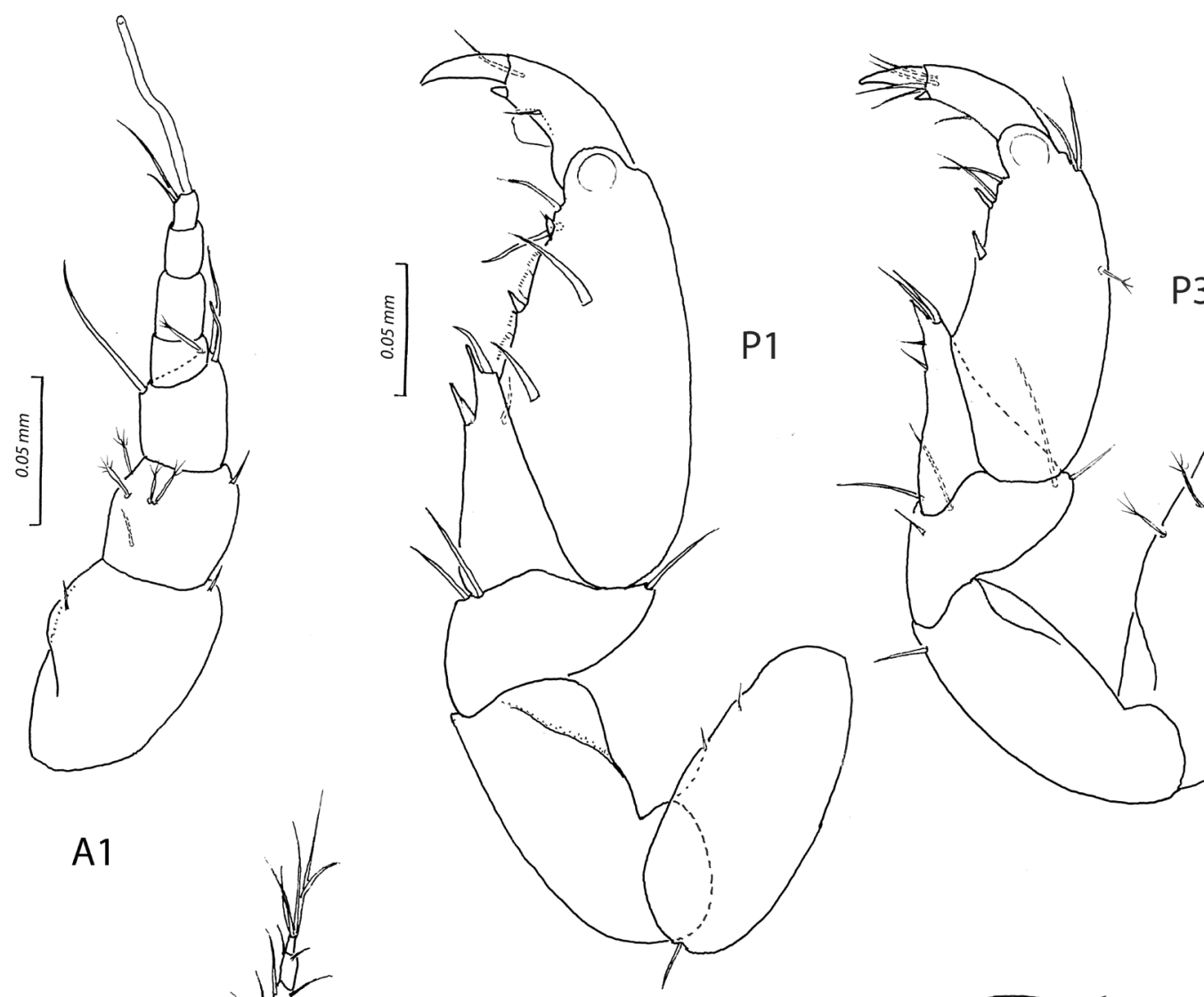

A1
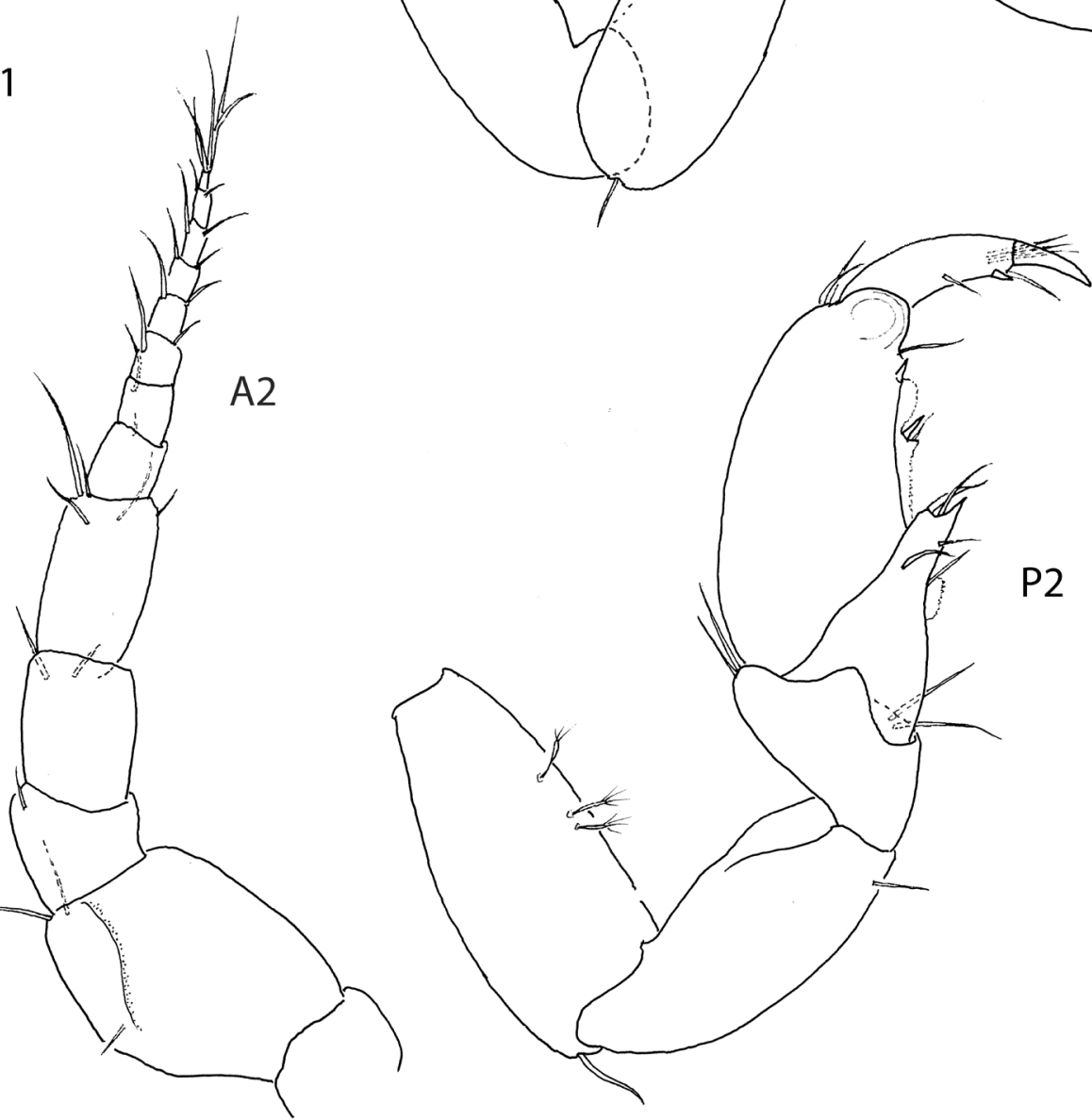

Fig. 7. Kupellonura indonesica sp. nov., holotype, immature adult (MZB Iso 100). Abbreviations: A1 = antenna $1 ; \mathrm{A} 2=$ antenna $2 ; \mathrm{P} 1-\mathrm{P} 3=$ pereopods $1-3$. 

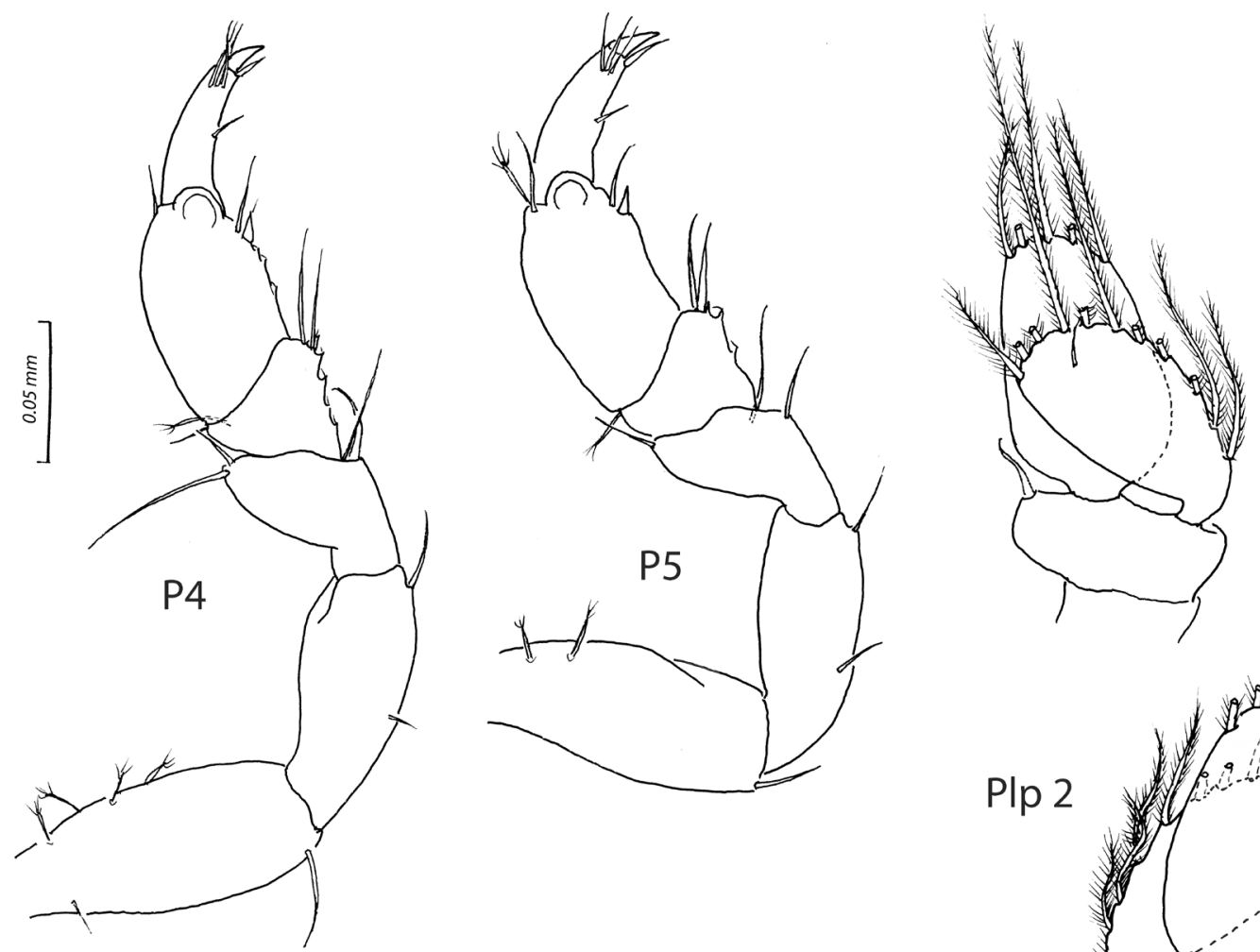

Plp 1

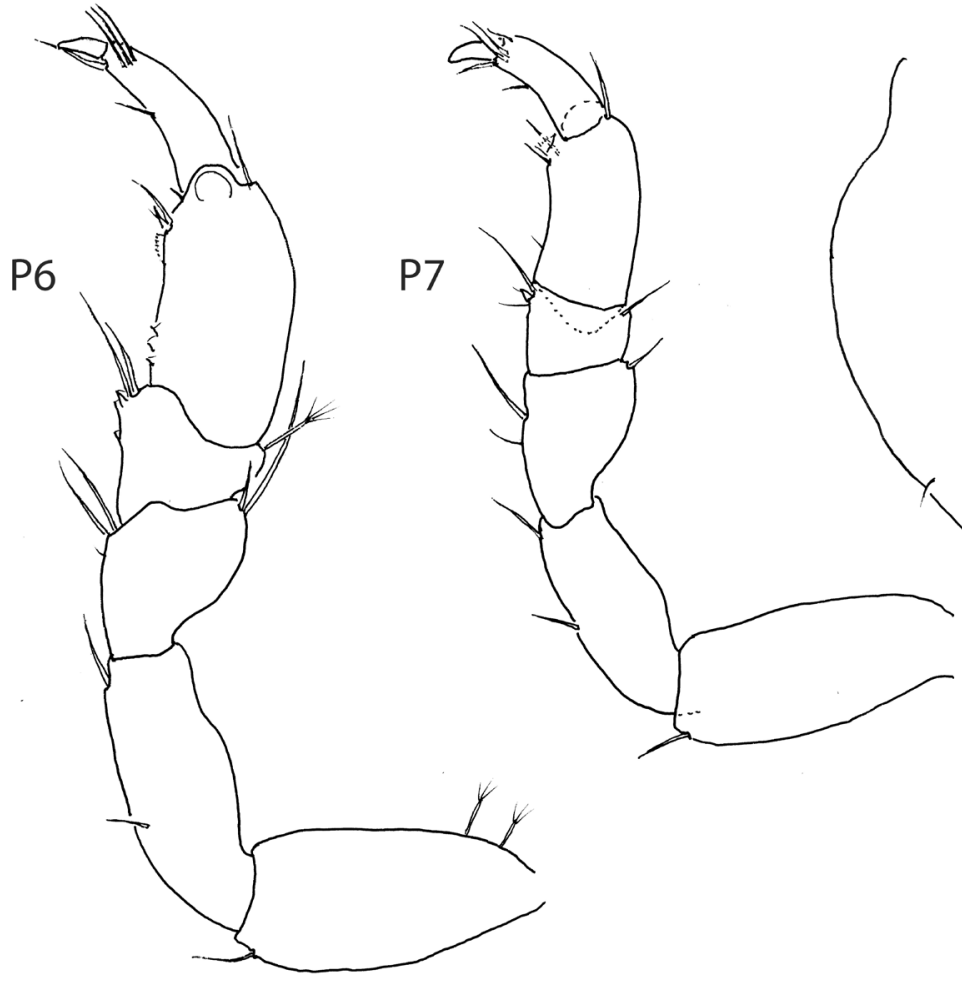

Plp 2

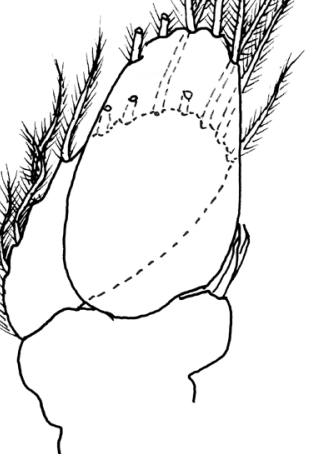

Fig. 8. Kupellonura indonesica sp. nov., holotype, immature adult (MZB Iso 100). Abbreviations: P4P7 = pereopods 4-7; Plp1-2 = pleopods 1-2; UEx = exopod of uropod. 


\section{Description of holotype}

BoDy. Without chromatophores, 13-14 times as long as wide (rostrum to tip of telson). Head slightly as long as wide, with a pair of small dorsolateral black eyes. A small rostral projection between antennae. Pereonites dorsally smooth, as long as wide, posterior segments (4-7) slightly wider than anterior ones; length ratio of pereonites: $1<2>3<4=5>6>7$. Pleonites $1-5$ free, as wide as pereonites, total length of pleonites 1-5 nearly length of pereonites $6+7$, lateroventral margins with some feather-like setae. Telson about as long as uropods and as length of three pleonites.

AntenNAE. Antenna 1 peduncle of three articles, first longest, articles 2 and 3 progressively shorter and slightly narrower, a conspicuous long seta on third article; flagellum about as long as first peduncle article, of four articles, with a single aesthetasc on last article. Antenna 2 peduncle with 5 articles, second article longest and widest; flagellum of 8 articles, somewhat as long as peduncle articles $4+5$, with several simple setae, longest on distal article.

MANDIBLE. With pointed but not sharp molar, lamina dentata with 4 teeth, incisor with two stout teeth; palp of three articles, distally only two simple setae, second article longest. Maxilla 1 lateral endite

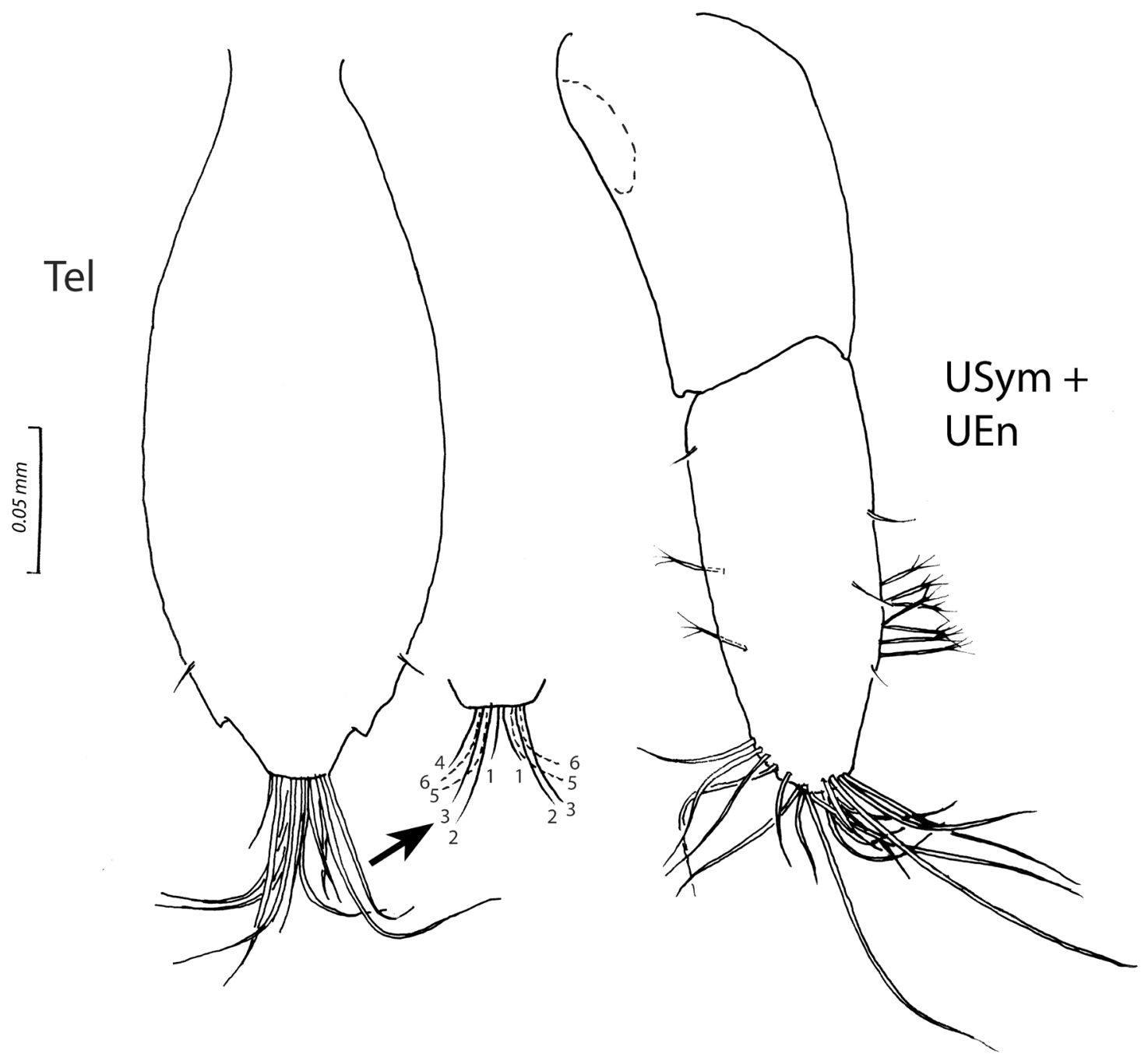

Fig. 9. Kupellonura indonesica sp. nov., holotype, immature adult (MZB Iso 100). Abbreviations: Tel = telson; Usym = sympod of uropod; Uen = endopod of uropod. 
apically with 5 curved spine-like teeth, spines 1.3 and 4 more slender than spine 2, apical spine 5 strongest; medial endite short, a single distal seta. Maxilliped with 5 palp articles, articles 2 and 3 longest and widest, last article small and narrow, with 3 apical simple setae; endite present, surpassing palp article 1 distally, with a single distal seta.

Pereopods. Pereopod 1 subchelate, carpus triangular with ventrodistal projection forming a spine in vicinity of a simple seta; more proximally a sensory spine; propodus with two prominent strong setae on mesial surface, on palm two short sensory spines and thin serrated cuticular scales; dactylus distally with a single claw and a short spine (second claw). Pereopod 2 of similar shape, however, propodus more slender, palm with 2 sensory spines and carpus projecting as in pereopod 1. Pereopod 3 similar to pereopod 2. Pereopods 4-6 similar, pereopod 7 weaker. Propodi with single short sensory spine on distoventral margin, propodus of P4 more oval than in P5-7, carpus trapezoidal with shorter dorsal margin.

Pleopods. All of similar shape, pleopod 1 exopod not larger than endopod; exopods of pleopods 1 and 2 distally with more swimming setae (11) than endopods (5). Uropod exopod long-oval, greatest width proximally, lateroventral margin forming a shallow lobe; length about 2.4 times greatest width, lateral margins smooth, a single short seta on each side, apex with several long simple setae. Endopod as long as sympod, shorter than exopod, elongated with rounded apex, on ventromedial margin a group of short plumose setae, two plumose setae more laterally; apex with many long and slender simple setae.

TeLSON. Tongue-like, lateral margins not parallel, distally on each side of apex a single prominent tooth; apex with central pair of short setae, and at each side of it another 5 setae.

\section{Remarks}

A combination of characters is typical of Kupellonura: above all the shape of the uropod exopod with its lobe on the lateral (ventrally directed) margin, then the blunt (not acute) molar process, the ventrodistal projection of the P1 carpus, the short rectangular carpus of P4-7, and the lack of autapomorphies of other genera (e.g., longer distoventral carpus projections on P2 or P3, reduced setation on pleopod endopods, shortened telson, strong spines on uropods).

Kupellonura flexibilis (Pasternak, 1982) (redescribed by Negoescu 1984) does not fit the generic diagnosis and needs redescription. The operculiform Plp 1 exopod indicates that this might not be a member of the family Hyssuridae.

The shape of the tail fan allows the identification of Kupellonura indonesica sp. nov. The new species differs from all other hitherto described species. The telson has no distolateral serrations except a pair of prominent indentations. A similar telson shape occurs in K. mediterranea Barnard, 1925 (see Wägele 1981a) and, with weak indentations, in K. werawera Poore \& Lew Ton, 1988, however, in these species the uropod exopod is medially strongly lobed. In comparison with other species the molar process of the mandible is more pointed.

Kupellonura macaroni sp. nov. urn:1sid:zoobank.org:act:1611D20A-56EF-43C8-A775-AAEC666BC7ED

Figs 10-13

\section{Differential diagnosis}

Very slender and elongated species of Kupellonura with a pair of small dorsolateral eyes, pereopod 1 carpus triangular with weak ventrodistal projection and two serrated stout spines; propodus with three prominent strong setae on mesial surface, on palm three short sensory spines; pereopods 2 and 


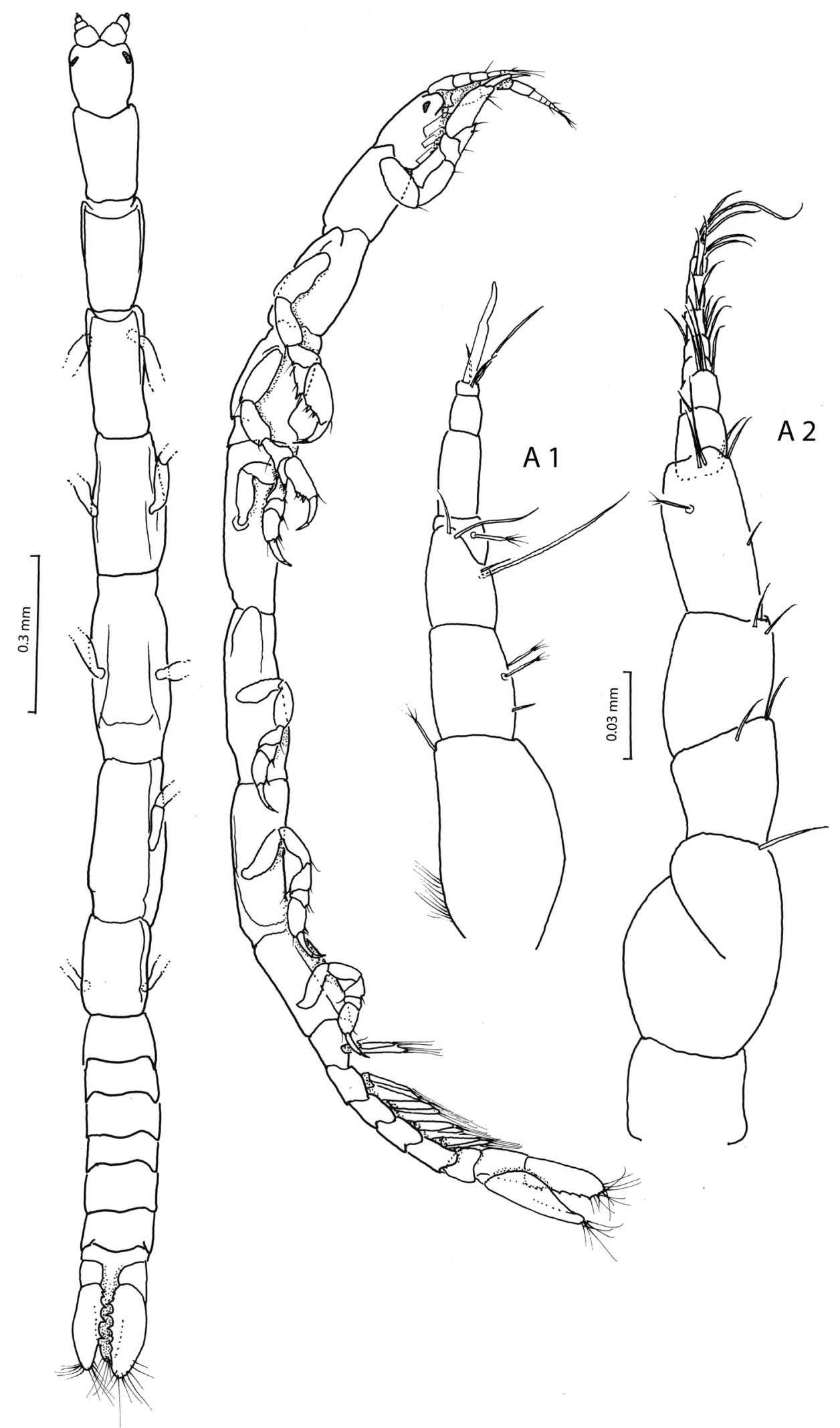

Fig. 10. Kupellonura macaroni sp. nov., holotype, immature adult, in dorsal and lateral view $(3.2 \mathrm{~mm})$ (MZB Iso 102). Abbreviations: A1 = antenna 1, A2 = antenna 2. 


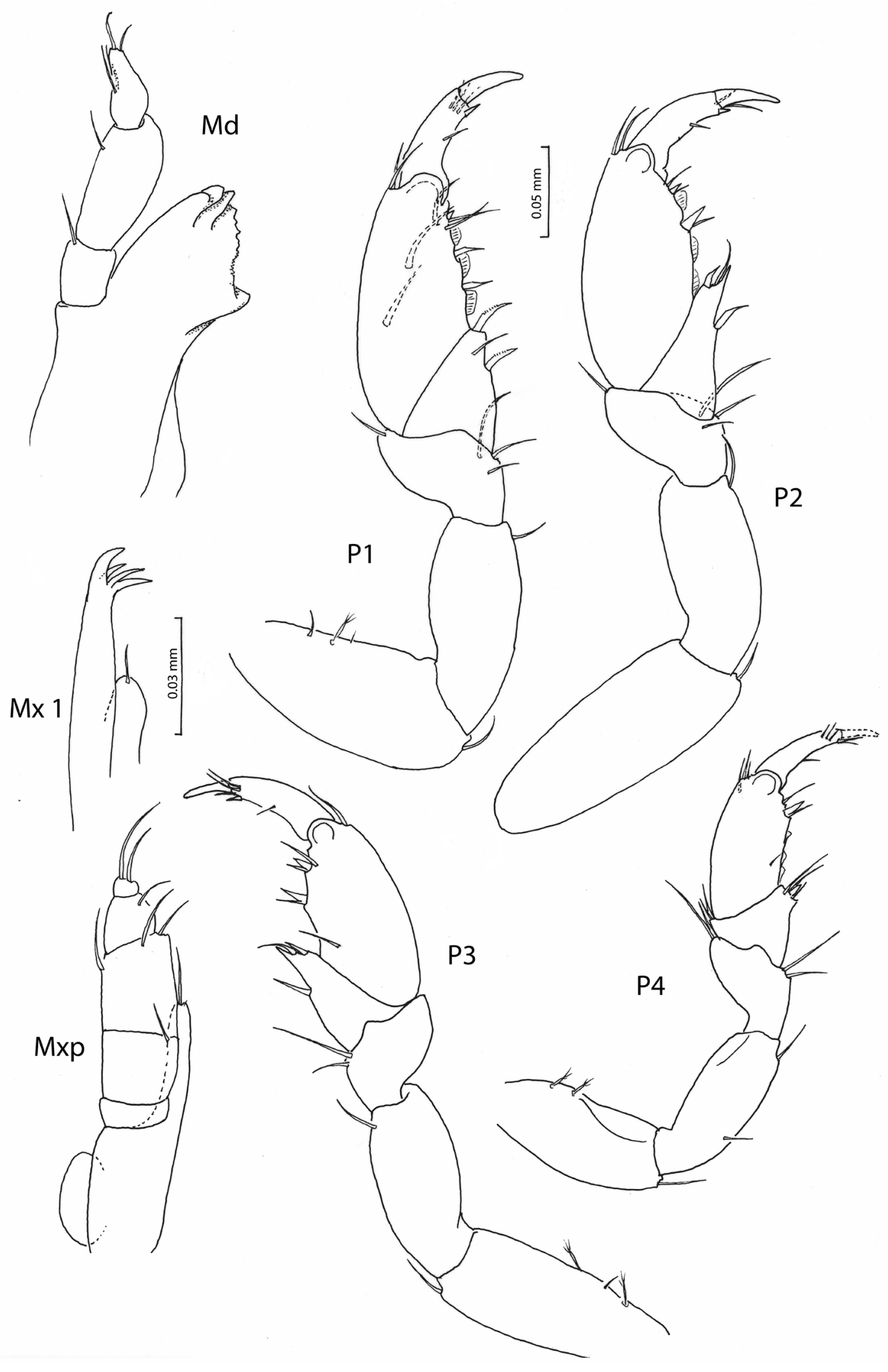

Fig. 11. Kupellonura macaroni sp. nov., holotype, immature adult (MZB Iso 102). Abbreviations: $\mathrm{Md}=$ mandible; Mx $1=$ maxilla $1 ;$ Mxp = maxilliped; $\mathrm{P} 1-\mathrm{P} 4=$ pereopods $1-4$. 

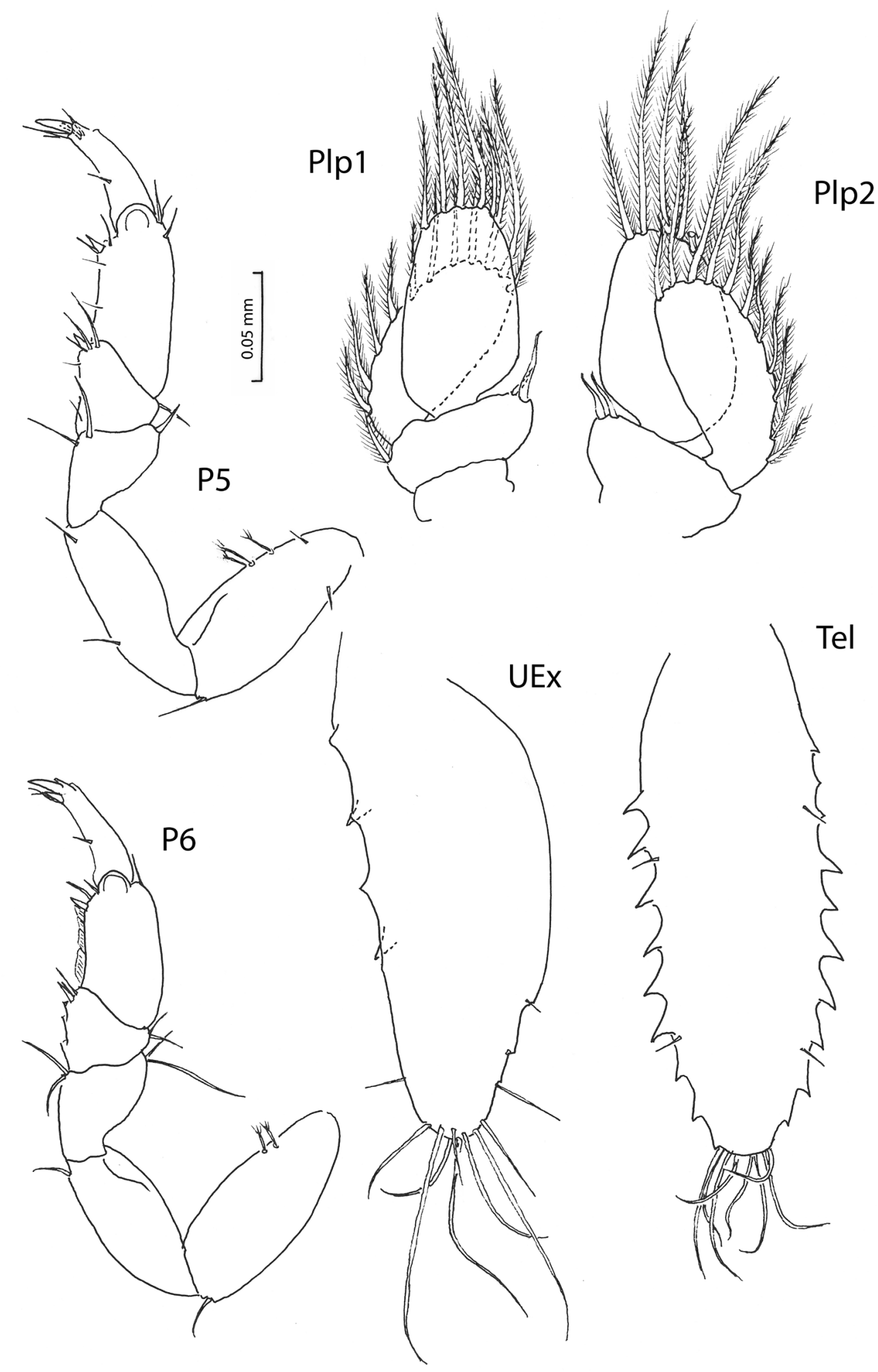

Fig. 12. Kupellonura macaroni sp. nov., holotype, immature adult (MZB Iso 102). Abbreviations: P5P6 = pereopods 5-6; Plp1-2 = pleopods 1-2, UEx = exopod of uropod; Tel = telson. 
3 of similar shape, propodus more oval, palm with 2 sensory spines, distal carpus corner projecting more than in pereopod 1; uropod exopod long-oval, lateroventral margin only weakly lobed, dorsal margin with 4-5 saw-teeth, uropod endopod as long as sympod, shorter than exopod, nearly rectangular, dorsomedial margin serrated, telson tongue-like, shape elongated oval, apex with 4 pairs of simple setae, lateral margins with $8-10$ large teeth.

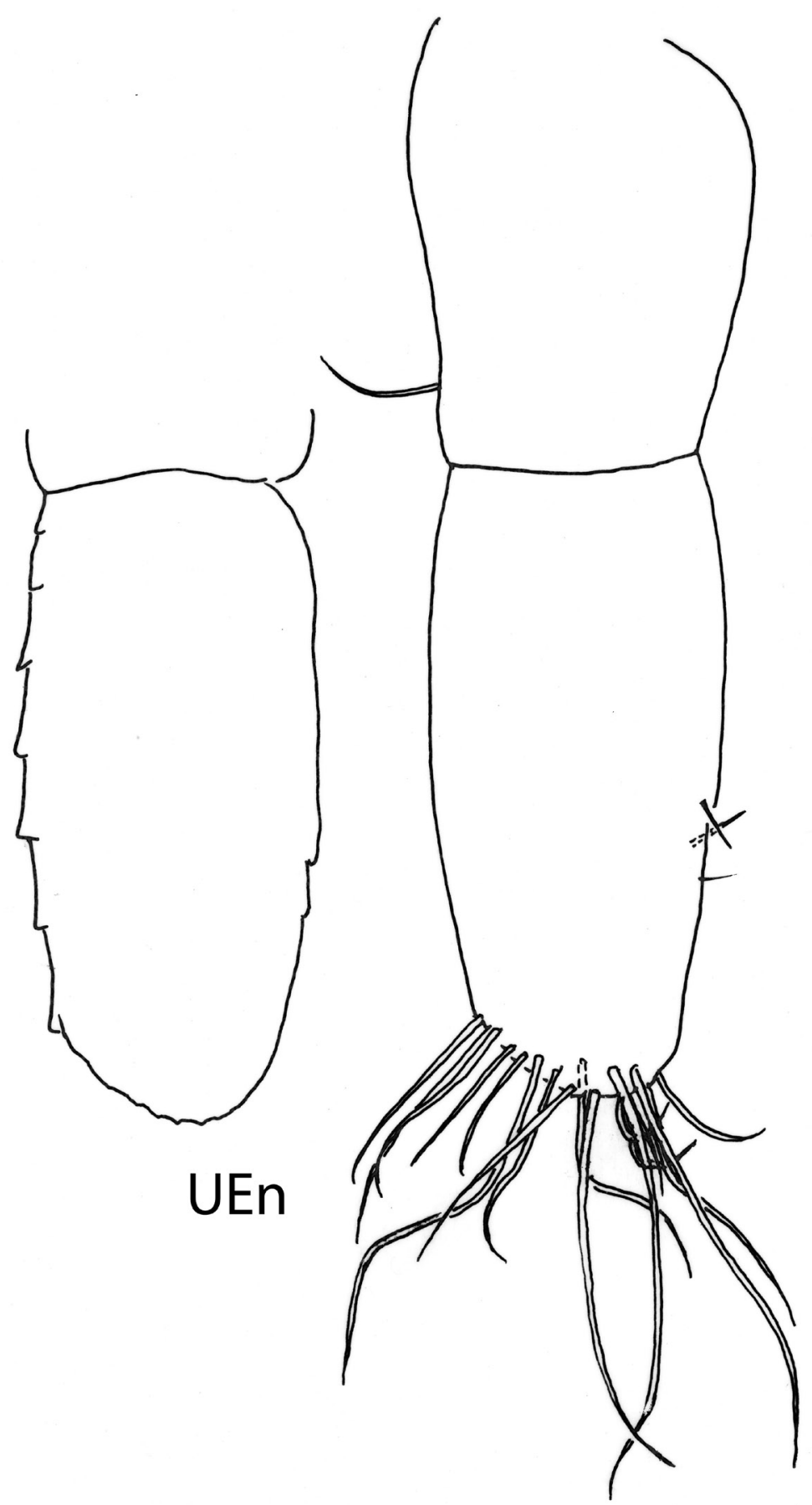

Fig. 13. Kupellonura macaroni sp. nov., holotype, immature adult (MZB Iso 102). Abbreviation: Uen = endopod of uropod, two views (setae omitted in left drawing). Serrations can be difficult to see at certain view angles. 
Many species of Kupellonura have weakly serrated telson margins, a stronger serration is seen in K. serritelson Wägele, 1981. The new species has the largest telsonic saw teeth of all known species of this genus and is therefore easily identified.

\section{Etymology}

Named after noodles because of the unusually narrow and elongated body shape of this species.

\section{Material examined}

\section{Holotype}

INDONESIA • immature adult (3.2 mm); Bangka Island, off the jetty of Coral Eye Resort; $1^{\circ} 44^{\prime} 22.04^{\prime \prime} \mathrm{N}$, $125^{\circ} 8^{\prime} 41.19^{\prime \prime}$ E; 2 m depth; from coral rubble; M. Annisaqois and J.W. Wägele leg.; 17 Sep. 2019; MZB Iso 102 .

\section{Paratype}

INDONESIA • manca stage $(2.0 \mathrm{~mm})$; Bangka Island, off the jetty of Coral Eye Resort; $1^{\circ} 44^{\prime} 22.04^{\prime \prime} \mathrm{N}$, $125^{\circ} 8^{\prime} 41.19^{\prime \prime}$ E; 2 m depth; from coral rubble; M. Annisaqois and J.W. Wägele leg.; 17 Sep. 2019; MZB Iso 103 .

\section{Description of immature adult}

Body. Without chromatophores, very slender, about 17 times as long as wide (rostrum to tip of telson). Head slightly as long as wide, with a pair of small dorsolateral black eyes. Pereonites dorsally smooth, as long as wide, posterior segments (4-7) slightly wider than anterior ones; length ratio of pereonites: $1<2=3<4<5>6>7$. Pleonites $1-5$ free, as wide as pereonites, total length of pleonites $1-5$ nearly length of pereonites $6+7$. Between pleonite 6 and telson dorsally a distinct edge. Lateroventral margins of pleonites with some feather-like setae. Telson about as long as uropods and pleotelson as a whole as long as four pleonites.

Antennae. Antenna 1 peduncle of three articles, first longest, articles 2 and 3 progressively shorter and slightly narrower, a conspicuous long seta on third article; flagellum shorter than first peduncle article, of four articles, with a single aesthetasc on last article. Antenna 2 peduncle with 5 articles, second article longest and widest, fifth article as long as articles 3 or 4; flagellum of 8 articles, about as long as peduncle articles $3+4$, with several simple setae.

MANDIBLE. With pointed but not sharp molar, lamina dentata with several small teeth, incisor with three cusps; palp of three articles, apically only two simple setae, second article longest. Maxilla 1 lateral endite apically with 4 curved spine-like teeth; medial endite short, a single distal seta. Maxilliped with 5 palp articles, articles 2 and 3 longest and widest, last article small and narrow, with 2 apical simple setae; endite long, surpassing palp article 2 distally, with a single distal seta.

PEREOPODS. Pereopod 1 subchelate, carpus triangular with weak ventrodistal projection and two serrated stout spines; propodus with three prominent strong setae on mesial surface, on palm three short sensory spines, the distal one short, and thin serrated cuticular scales; dactylus distally with a single claw and a short spine. Pereopod 2 of similar shape, however, propodus more oval, palm with 2 sensory spines, distal one shorter, distal carpus corner projecting more than in pereopod 1, with an acute point, two stout spines on margin. Pereopod 3 roughly similar to pereopod 2. Pereopods 4-6 similar, pereopod 7 weaker. Propodi with single short sensory spine on distoventral margin, carpus trapezoidal with shorter dorsal margin.

Pleopods. All of similar shape, pleopod 1 exopod not larger than endopod; exopods of pleopods 1 and 2 distally with more swimming setae (11) than endopods (5). Uropod exopod long-oval, lateroventral 
margin only weakly lobed, dorsal margin with 4-5 saw teeth-like structures, not visible from all angles; length about 2.7 times greatest width, apex with several long simple setae. Endopod as long as sympod, shorter than exopod, nearly rectangular, dorsomedial margin serrated, teeth not visible from all angles; apex with many long and slender simple setae.

Telson. Tongue-like, shape elongated oval, length 2.6 times greatest width, apex with 4 pairs of simple setae, lateral margins with 8-10 large teeth (in type specimen no perfect left-right symmetry).

\section{Remarks}

In contrast to the aforementioned species, the convexity of the ventral margin of the uropod exopod, typical for many species of Kupellonura, is inconspicuous in this species. The strong teeth on the telson and the uropod serration resemble the tail fan of species of Neohyssura; however, in Neohyssura the telson is elongated triangular, the spines are more voluminous and very large on the uropod exopod, furthermore, $\mathrm{P} 2$ is distinctly stronger than $\mathrm{P} 3$ and the carpus of $\mathrm{P} 4-7$ is longer.

Family Anthuridae Leach, 1814

Genus Pendanthura Menzies \& Glynn, 1968

\section{Type species}

Pendanthura tanaiformis Menzies \& Glynn, 1968. Until now, 10 species have been described in this genus, all of them from tropical Atlantic and Indo-Pacific localities and mostly from very shallow habitats. The deepest record is $430 \mathrm{~m}$ off Lifou Island (Negoescu 1994).

Pendanthura bangkaensis sp. nov. urn:1sid:zoobank.org:act:465C0098-760A-4D0B-B566-5C2D8EB5ADCC

Figs 14-17

\section{Differential diagnosis}

Species of Pendanthura with dorsally pigmented body, distinct lateral eyes with few large ommatidia, mandible palp with 1 tiny article and a long apical seta, pereopod 1 carpus triangular with protruding edge distally, propodus lower half protruding, forming a rounded corner near palm center, with 14 setae in mesial row on distal half of propodus, and 5 longer setae more proximally; pereopods 2-3 merus triangular, dorsal edge reaching nearly to propodus, uropod sympod elongate, endopod subovate, medially as long as laterally, about 0.3 sympod length, exopod twice length of endopod, long oval, margin with many short feathered setae; margins of endopod, exopod and tip of telson weakly crenulated. Telson tongue-shaped, with a pair of statocyst proximally, rounded apex bearing 3 pairs of setae, and on dorsal surface another 2 pairs of longer setae and 1 pair of short setae.

Few species of Pendanthura share with the new species the distinct projection near the center of the palm of P1 propodus. This feature also occurs in P. rarotonga Kensley, 1979. Müller (1992) described a specimen of $P$. rarotonga from Bora Bora with 1 article and 2 short setae of the mandibular palp, and a pereopod 1 palm more convex in its lower half and with a sharper protrusion than in Kensley's material (1979). Müller's species from Bora Bora is probably not the same as P. rarotonga of Kensley (1979), which occurs on Rarotonga Island. In Pendanthura bangkaensis sp. nov. from Sulawesi the palm projection of the female is similar, but the mesial row of setae has more setae (14 instead of 8). Also, in $P$. rarotonga the telson bears dorsally 4-7 pairs of setae, in the Sulawesi material there are only 2 pairs of long setae and a pair of short seta dorsolaterally. A similar but larger P1 palm protrusion also occurs in P. tanaiformis Menzies \& Glynn, 1968, a Caribbean species. Uropod details of this species are still undescribed. 

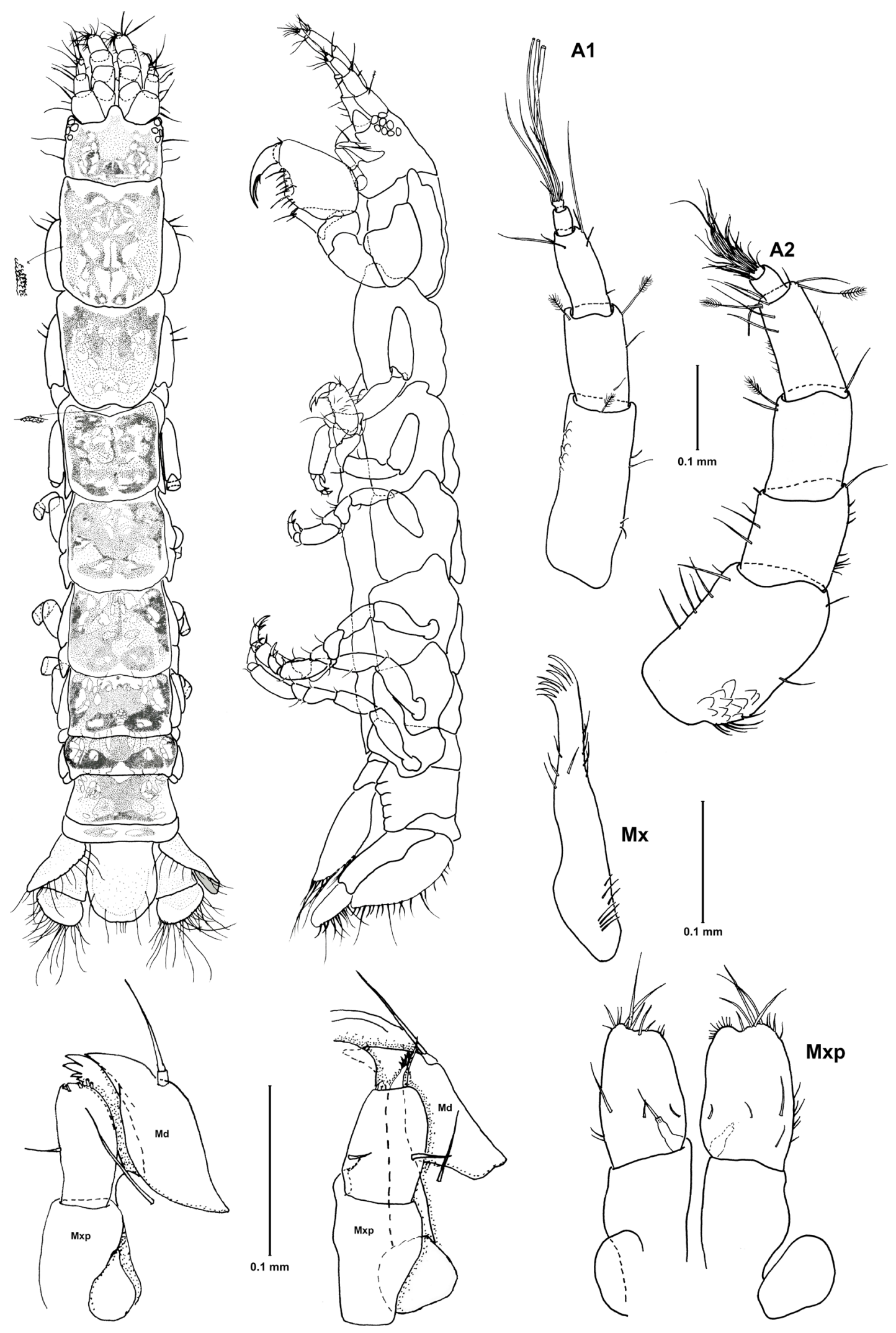

Fig. 14. Pendanthura bangkaensis sp. nov., holotype, + , in dorsal and lateral view (3.4 mm) (MZB Iso 104). Abbreviations: $\mathrm{A} 1=$ antenna $1 ; \mathrm{A} 2=$ antenna $2 ; \mathrm{Md}=$ mandible; $\mathrm{Mx}=$ maxilla; $\mathrm{Mxp}=$ maxilliped. 

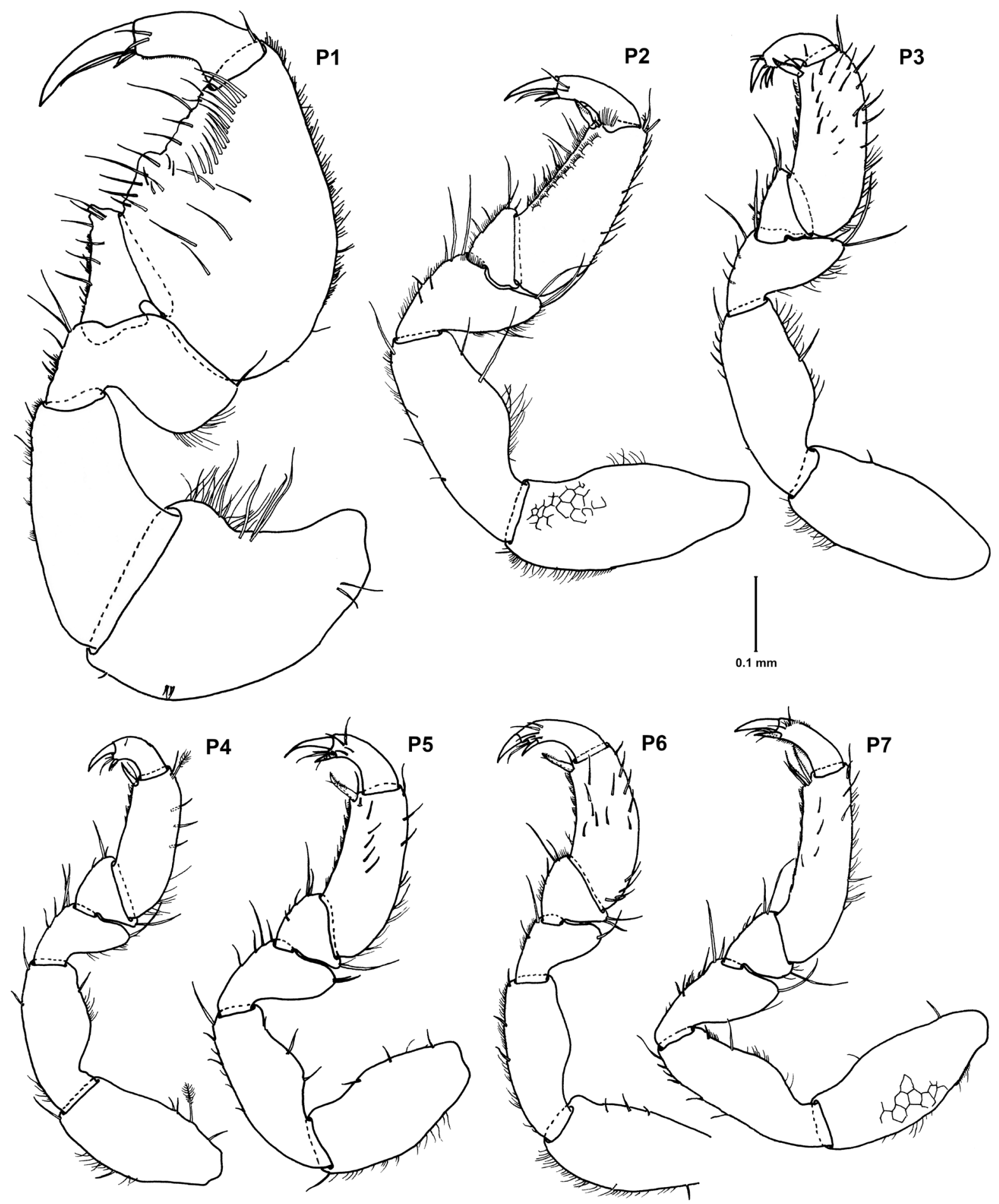

Fig. 15. Pendanthura bangkaensis sp. nov., + , holotype (MZB Iso 104). Abbreviations: P1-P7 = pereopods 1-7. 

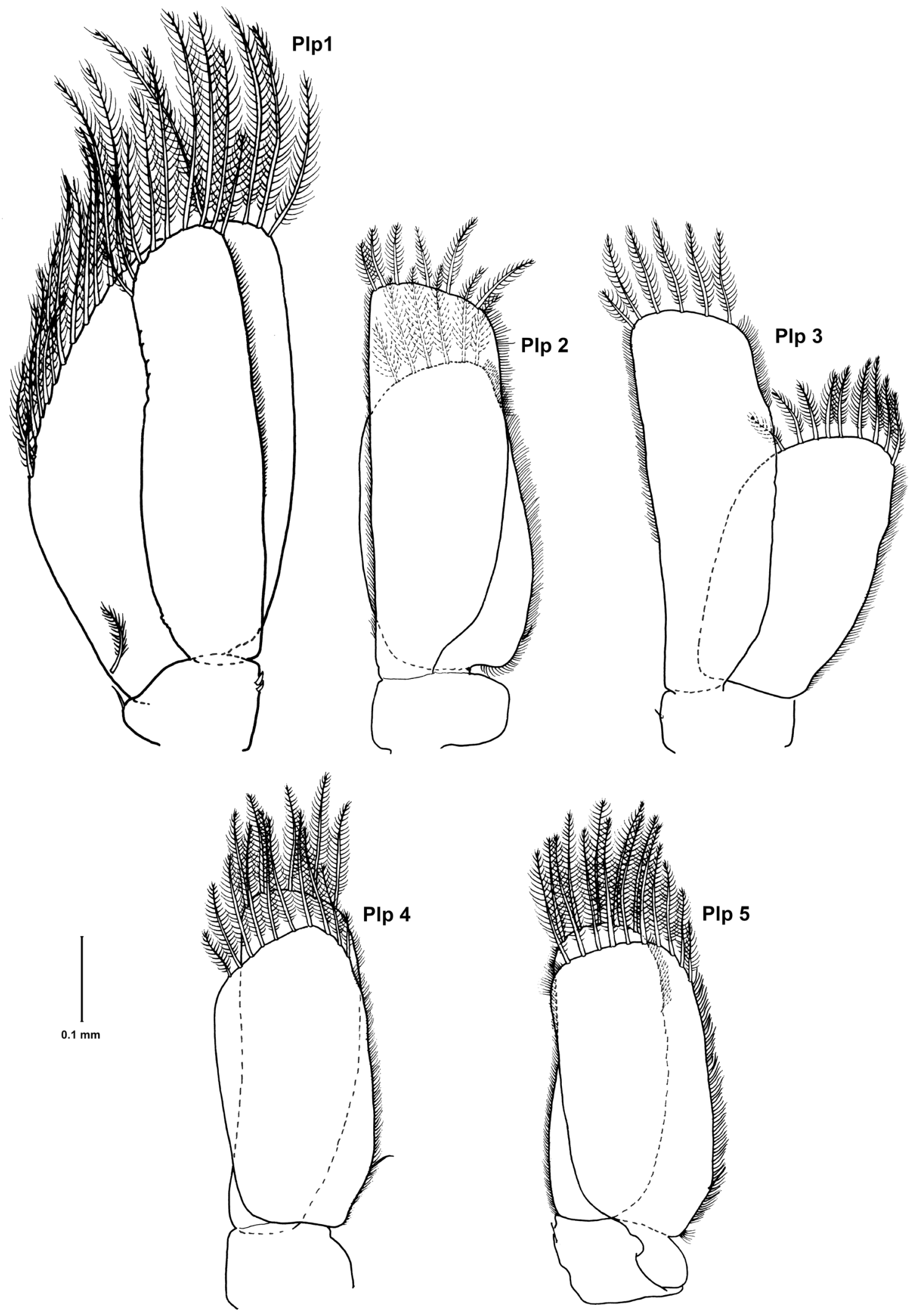

Fig. 16. Pendanthura bangkaensis sp. nov., , , holotype (MZB Iso 104). Abbreviations: Plp 1-Plp $5=$ pleopods 1-5. 


\section{Etymology}

The species epithet refers to the type locality.

\section{Material examined}

\section{Holotype}

INDONESIA • brooding 9 ( $(3.4 \mathrm{~mm})$; Bangka Island, offCoral Eye Resort; $1^{\circ} 44^{\prime} 22.04^{\prime \prime} \mathrm{N}, 125^{\circ} 8^{\prime} 41.19^{\prime \prime} \mathrm{E}$; 1-2 m depth; in coral rubble; M. Annisaqois and J.W. Wägele leg.; Sep. 2019; MZB Iso 104.
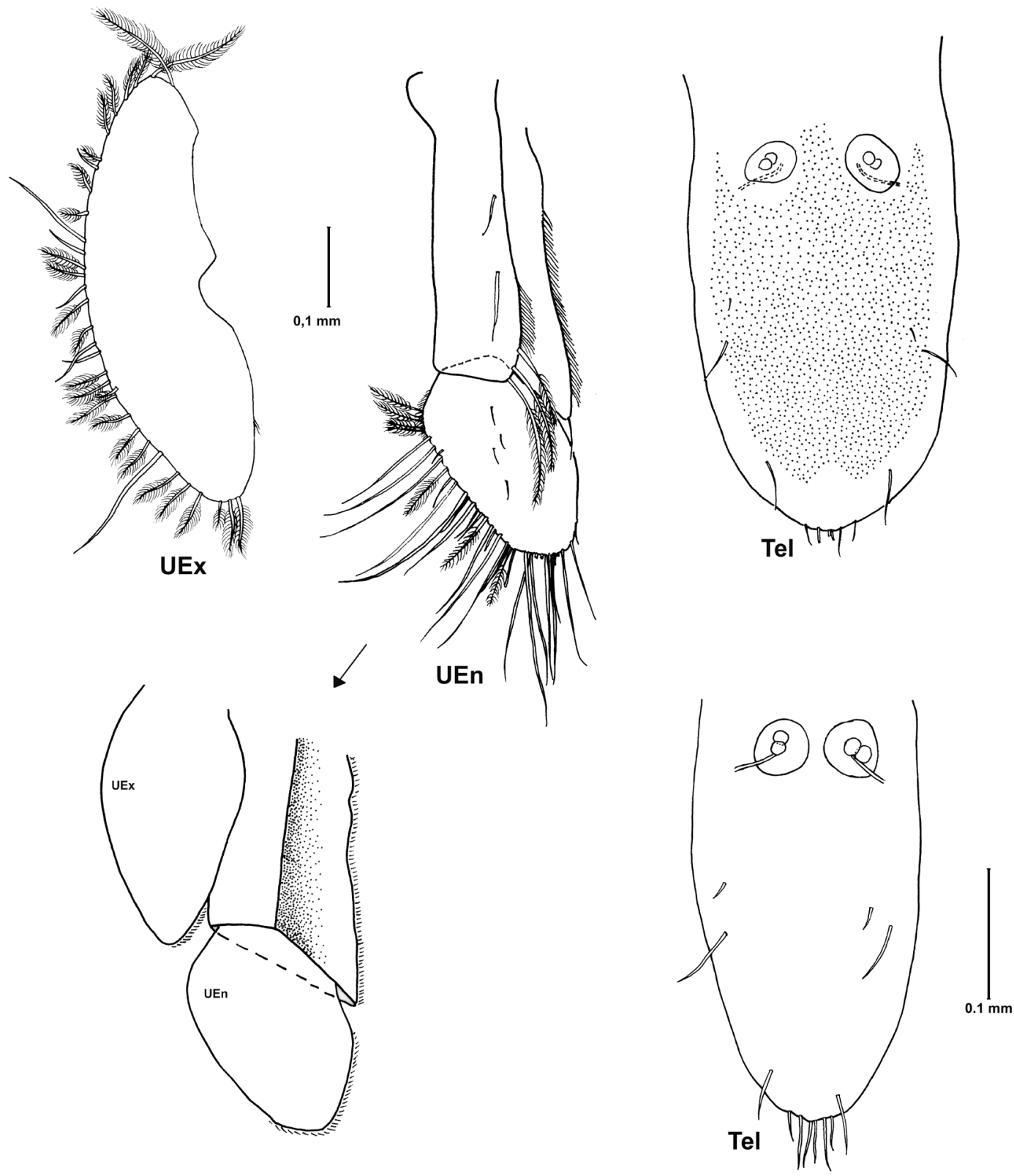

Fig. 17. Pendanthura bangkaensis sp. nov., $q$, holotype (MZB Iso 104). Abbreviations: UEx = exopod of uropod; UEn = endopod of uropod; Tel = telson. 
Paratypes

INDONESIA • 2 q $q$ (2.8-3.4 mm); Bangka Island, off Coral Eye Resort; $1^{\circ} 44^{\prime} 22.04^{\prime \prime} \mathrm{N}, 125^{\circ} 8^{\prime} 41.19^{\prime \prime} \mathrm{E}$; 1-2 m depth; in coral rubble; M. Annisaqois and J.W. Wägele leg.; Sep. 2019; MZB Iso 105.

\section{Description of holotype}

BoDy. About 8.1 times as long as greatest width, dorsally pigmented, small cuticular scales on body and part of appendages. Cephalothorax in dorsal view wider than long, a pronounced rounded rostrum between insertion of antennae, a pair of compound eyes with few ommatidia. Body proportions: $\mathrm{C}<1>2$ $>3>4>5>6>7$. Pleonites 1-5 fused, together wider than long, length about as pereonite 6 .

Antennae. Antenna 1 peduncle article 1 longest, about 2.3 times as long as wide, articles 2 and 3 progressively narrower, article 2 as long as article 3 ; flagellum of 2 articles, last article with 3 aesthetascs and 5 setae. Antenna 2 with very short flagellum, basal flagellar article slightly as long as wide. Mandible palp with 1 tiny article and a long apical seta. Maxilla 1 distally with 7 pointed teeth. Maxilliped palp of only 1 article, roughly rectangular, center of apex with concavity, distally with 5 simple setae and 5 medial setae on ventral palp surface, endite short, sub-triangular, apex bearing 1 seta.

Pereopods. Pereopod 1 subchelate, basis about 1.3 times as long as greatest width, merus dorsal part trapezoidal, carpus triangular with protruding edge distally, propodus lower half protruding, forming a rounded corner near palm center, with 14 setae in mesial row on distal half of propodus, and 5 longer setae more proximally. Propodus of pereopods 2-6 distally with 1 sensory spine on palm. Pereopods 2-3 not subchelate, merus triangular, dorsal edge reaching nearly to propodus. Pereopod 2 propodus with cuticular scales laterally. Pereopods 4-6 merus nearly triangular, slightly as long as carpus. Pereopod 7 propodus as long as in pereopods $2-6$.

ExopoDs. Exopod of pleopod 1 operculiform, distal margin with 16 feathered setae, endopod about $1 / 2$ of exopod width, margin with 9 feathered setae. Exopod of pleopods $2-5$ as long as endopod. Pleopods 2-3 exopod distally with 6 feathered setae, endopod pleopod 2 with 6 feathered setae and 9 feathered setae on pleopod 3. Exopod of pleopods 4-5 with 5 feathered setae and endopod with 10 feathered setae, respectively. Uropod sympod elongate, distal margin with 3 feathered setae, endopod subovate, medially as long as laterally, about 0.3 sympod length. Exopod of uropod twice length of endopod and elongate oval, margin with 26 short feathered setae and 7 simple setae. Margins of endopod, exopod and tip of telson weakly crenulated. Telson tongue-shaped, with a pair of statocyst proximally, rounded apex bearing 3 pairs of setae, and on dorsal surface another 2 pairs of longer setae and 1 pair of short setae.

\section{Remarks}

This species belongs to the Pendanthura group of genera discussed by Poore (2001). Within the family Anthuridae, Stygocyathura Botosaneanu \& Stock, 1981, Cyathura Norman \& Stebbing, 1886, Pendanthura Menzies \& Glynn, 1986 and Sauranthura Poore \& Kensley, 1981 possess a shortened pleon, shortest in Pendanthura, and they lack sensory spines distally on the carpus of P4-7. Pendanthura Menzies \& Glynn, 1968 is characterized by a pronounced rostrum, a maxilliped palp of only 1 rectangular article, and a very short uniarticulate mandibular palp.

There are 10 named species that can be assigned to the genus, and there is a description of an unnamed species from Kalimantan (see Negoescu 1997). Species of Pendanthura have been found mostly in tropical seas. Most characters useful to distinguish the species can be found in the pereopod 1 propodus palm shape. The palm is generally convex, usually more so in its proximal half. The shape varies somewhat between the sexes, and males have a denser set of setae. 
ANNISAQOIS M. \& WÄGELE W.J., Anthuroidea (Crustacea, Isopoda) from Sulawesi

Family Expanathuridae Poore, 2001

Genus Expanathura Wägele, 1981

\section{Type species}

Expanathura amstelodami (Kensley, 1976). There are 6 described species that have been assigned to this genus. These occur only in Indo-Pacific reef areas and Madagascar, typically in shallow water (rarely deeper than $10 \mathrm{~m}$ ).

Expanathura collaris Kensley, 1979

Figs 18-23

Panathura collaris Kensely, 1979: 823, figs 7-9.

Panathura collaris - Müller 1993: 329, figs 172-202 (re-description).

Expanathura collaris - Wägele 1981b: 89 (new genus). — Negoescu 1999:214, figs 9-11.—Negoescu \& Brandt 2001: 121, figs 14-18. — Poore \& Lew Ton 2002: 26, figs 16-19, 20 a.

\section{Material examined}

INDONESIA • $\bigcirc(2.5 \mathrm{~mm})$; Bangka Island (North Sulawesi), off Coral Eye Resort; $1^{\circ} 44^{\prime 2} 20.22^{\prime \prime} \mathrm{N}$, $125^{\circ} 8^{\prime} 46.07^{\prime \prime} \mathrm{E}$; $1-2 \mathrm{~m}$ depth; in coral rubble, dissected specimen; M. Annisaqois and J.W. Wägele leg.; Sep. 2019; MZB Iso $106 \bullet 4$ other specimen (2.0-3.1 mm); same collection data as for preceding; MZB Iso 107.

\section{Description of female from Bangka Island}

Body. Slender, dorsal head pigmentation V-shaped.

ANTENNAE. Antenna 1 first article of peduncle 1.27 as long as wide, three flagellar articles, last article bearing 2 aesthetascs. Antenna 2 peduncle second article distally with distinct protrusion, with 5 short flagellar articles.

MANDible PALP. With 3 articles, last article bearing 7 short setae, and - as is typical for the genus - the endite is slender and lacks a molar process, lamina dentata is present, the pars incisive small. Maxilla 1 distally with 5 spine-like teeth. Maxilliped palp with 5 articles, stout endite does not reach palp article 4 .

PeReopods. Pereopod 1 propodus palm proximally with 1 protruding and apically rounded point, more distally a less protruding crenulated tooth and distal half of palm crenulated, carpus palm with protruding shorter rounded point distally. Pereopod 2 propodus palm proximally with 1 slender and curved protrusion, followed distally by edge with 1 shorter protrusion and some notches, distal half of edge irregularly crenulated. In other, smaller specimens the crenulations on P1 are weaker (see Fig. 21). Pereopod 7 propodus dorsal margin with 2 trifurcate setae.

PLEOPOD 1 ENDOPOD. Narrower and shorter than the broad exopod, distally narrower than proximally, with 3 apical feathered setae, exopod with 12 feathered setae. In other specimens (see Fig. 21) the number of setae on the pleopod 1 endopod varies between 2 and 5. Uropod exopod outer margin proximal half nearly straight, distal half with concavity, in between a rounded point.

TeLson. With convex margins, broadest nearly in the middle of its length, with a pair of lateral setae on broadest part, a pair of very short setae centrally on apex, rounded distal margin bearing 3 further pairs of long setae and 3 pairs of short setae; dorsally 2 pairs of short setae on telson. Shape and setation of uropod and telson vary a little in smaller specimens (Fig. 21). 

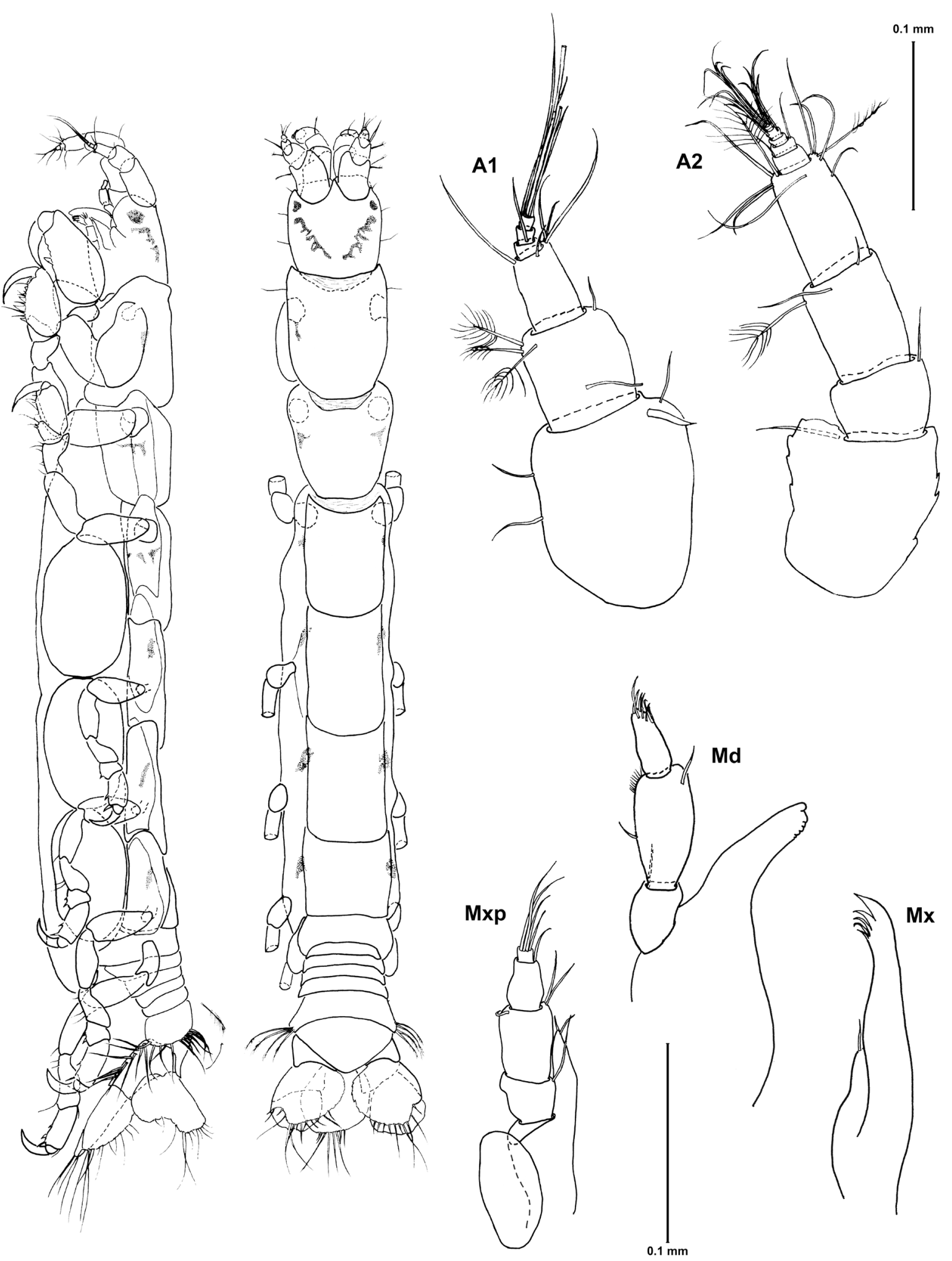

Fig. 18. Expanathura collaris (Kensley, 1979). Ovigerous $q$ from Bangka Island, in dorsal and lateral view $(2.5 \mathrm{~mm})$ (MZB Iso 106). Abbreviations: $\mathrm{A} 1=$ antenna $1 ; \mathrm{A} 2=$ antenna $2 ; \mathrm{Md}=$ mandible; $\mathrm{Mx}=$ maxilla, $\mathrm{Mxp}=$ maxilliped. 

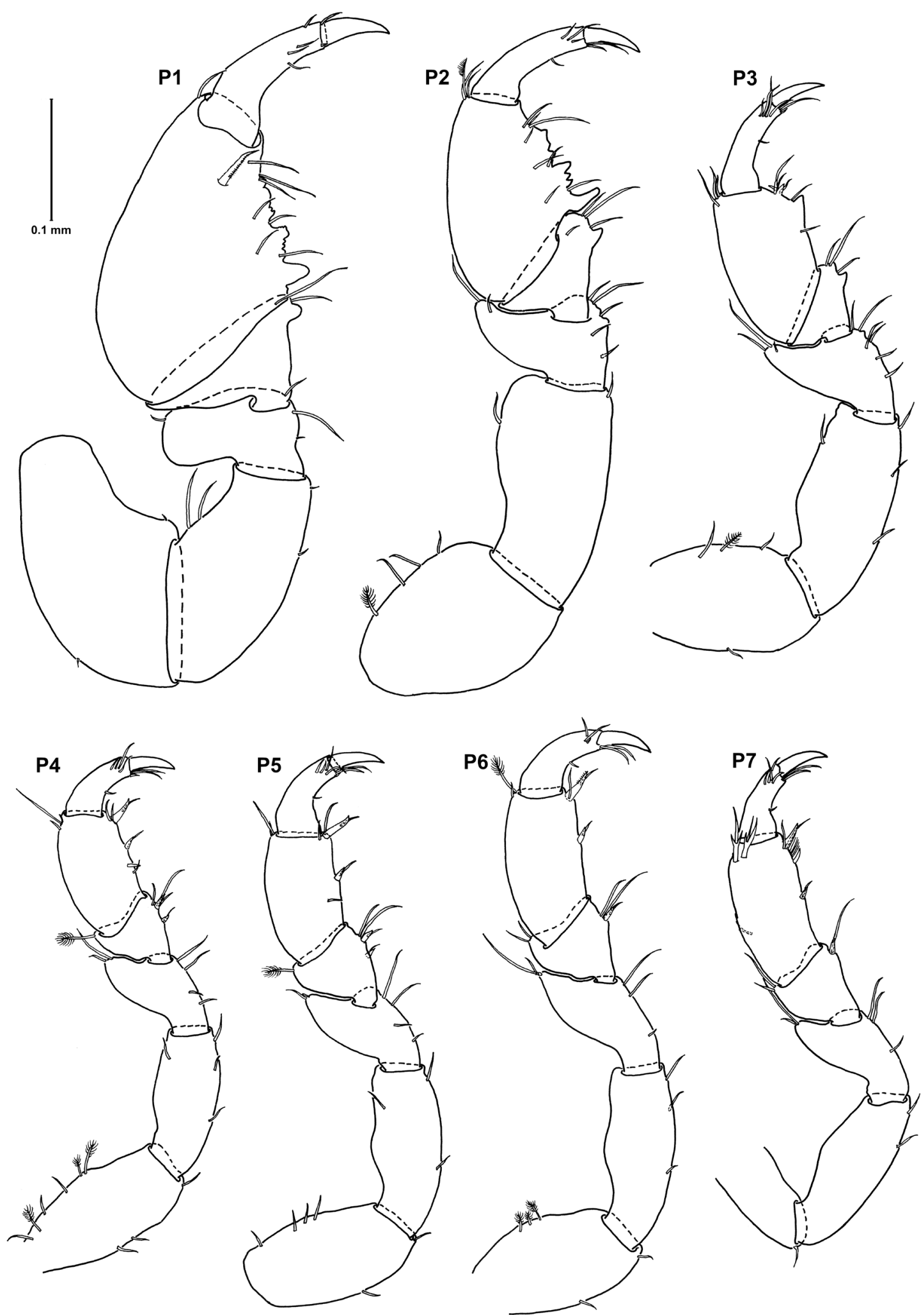

Fig. 19. Expanathura collaris (Kensley, 1979) (MZB Iso 106). Ovigerous $q$ from Bangka Island. Abbreviations: $\mathrm{P} 1-\mathrm{P} 7=$ pereopods $1-7$. 

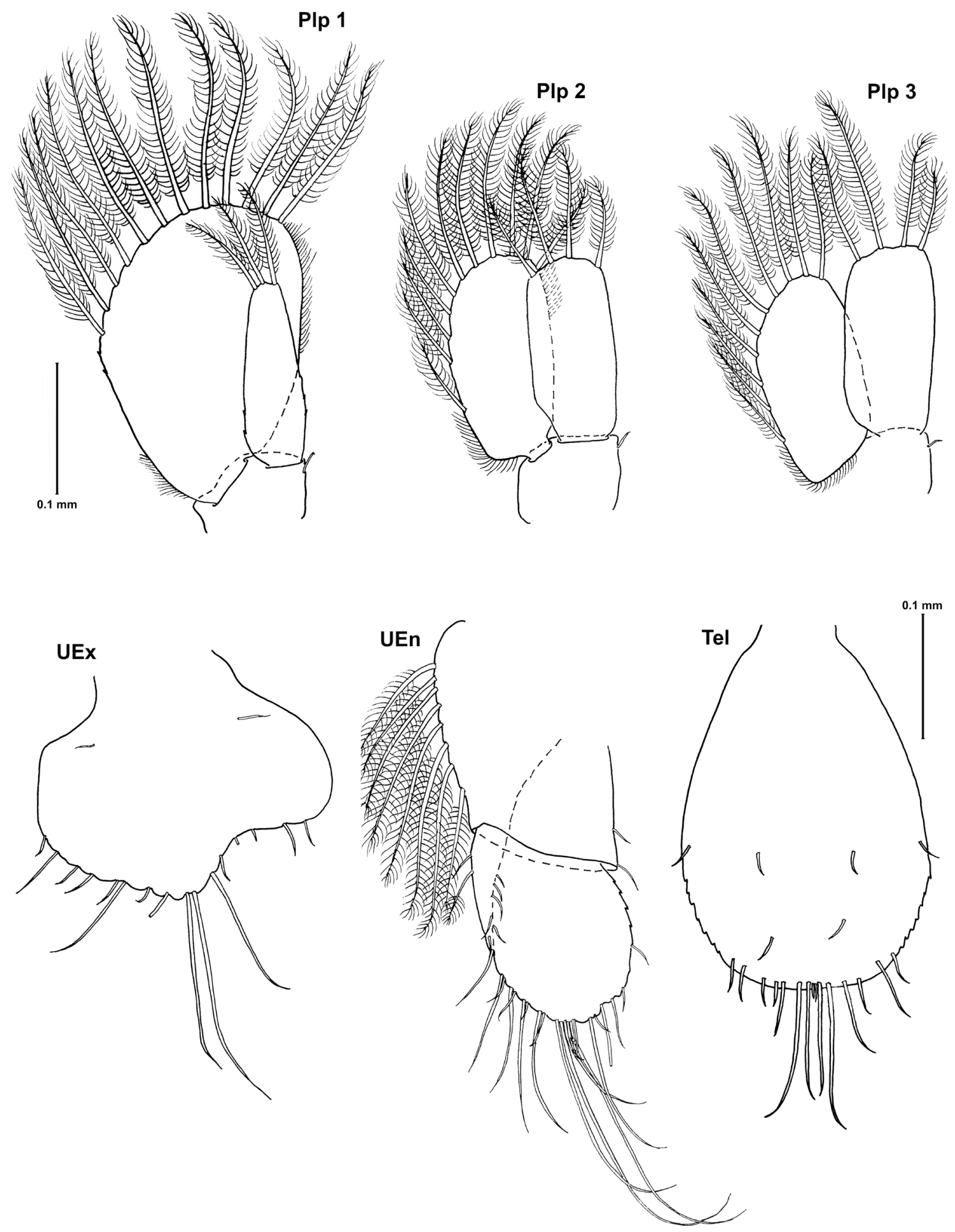

Fig. 20. Expanathura collaris (Kensley, 1979) (MZB Iso 106). Ovigerous $\circ$ from Bangka Island. Abbreviations: Plp 1-3 = pleopods 1-3; UEx = exopod of uropod; UEn = endopod of uropod; Tel = telson. 
P1
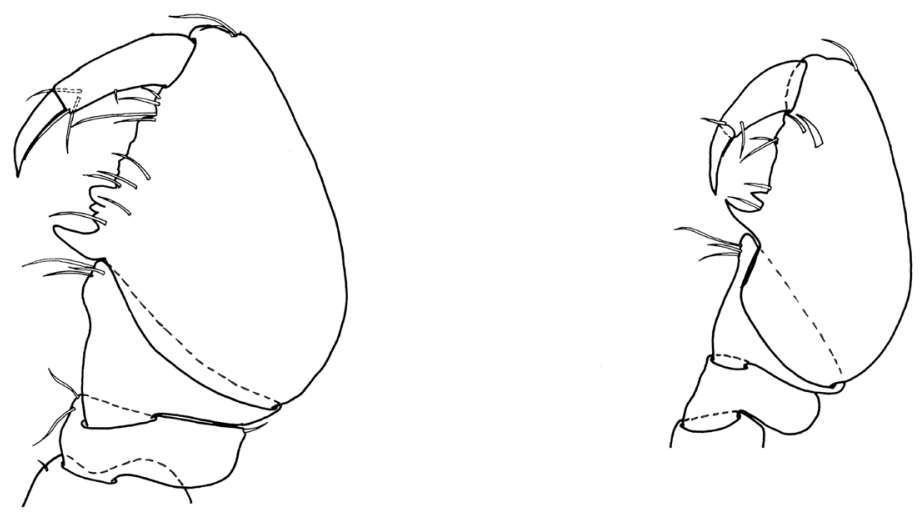

PIp 1

Tel \& UEx
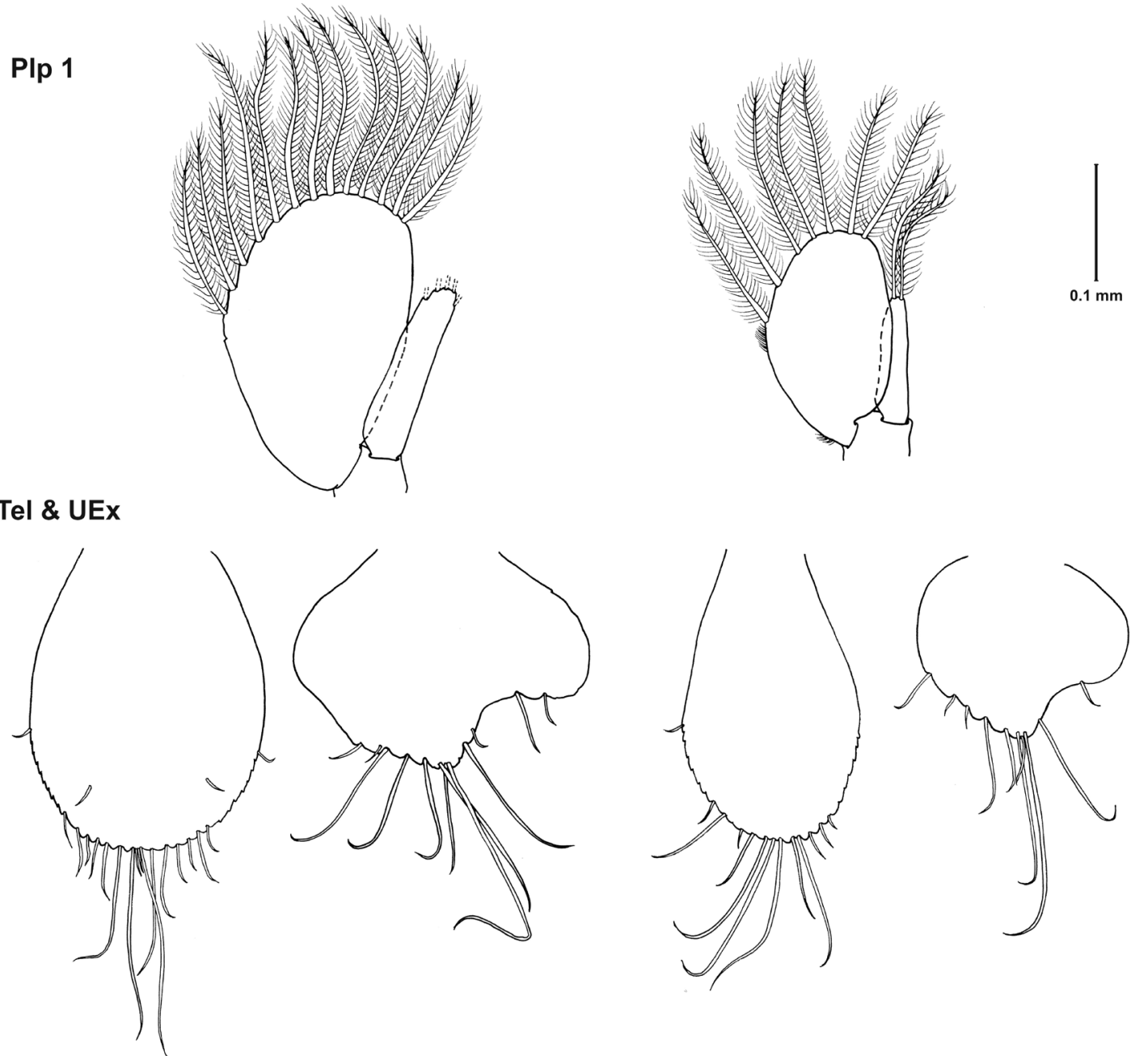

Fig. 21. Expanathura collaris (Kensley, 1979), immature specimens from Bangka Island showing variations (MZB Iso 107). Left: specimen of $2.5 \mathrm{~mm}$; right: specimen of $2.2 \mathrm{~mm}$. Abbreviations: P1 = pereopod 1; Plp1 = pleopod 1; UEx = exopod of uropod; Tel $=$ telson. 

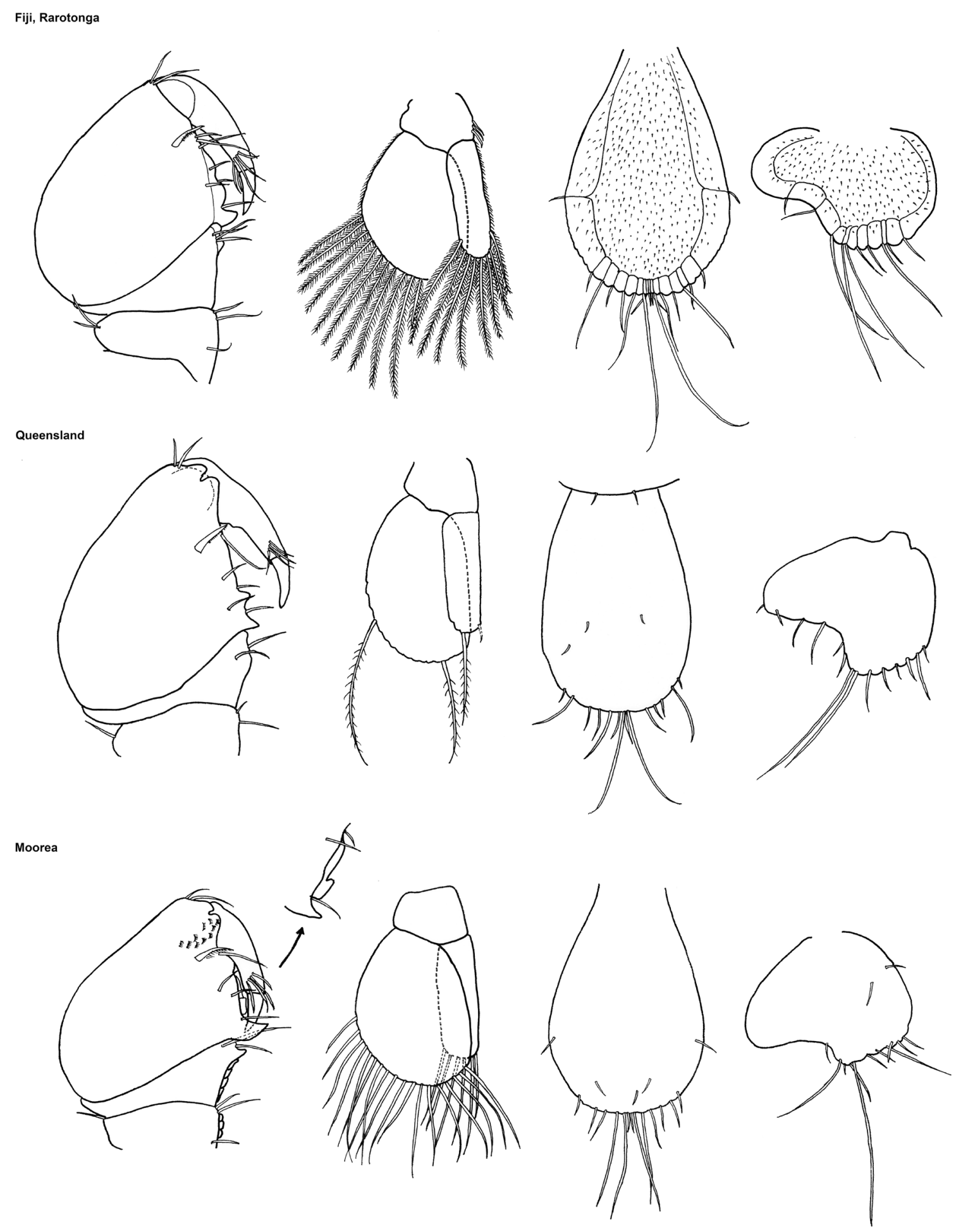

Fig. 22. Expanathura collaris (Kensley, 1979), comparison of published descriptions. Pereopod 1, pleopod 1, telson and exopod of uropod. Populations from Fiji (after Kensley 1979), Queensland (after Poore 2002) and Moorea (after Müller 1993). 


\section{Fiji Island}
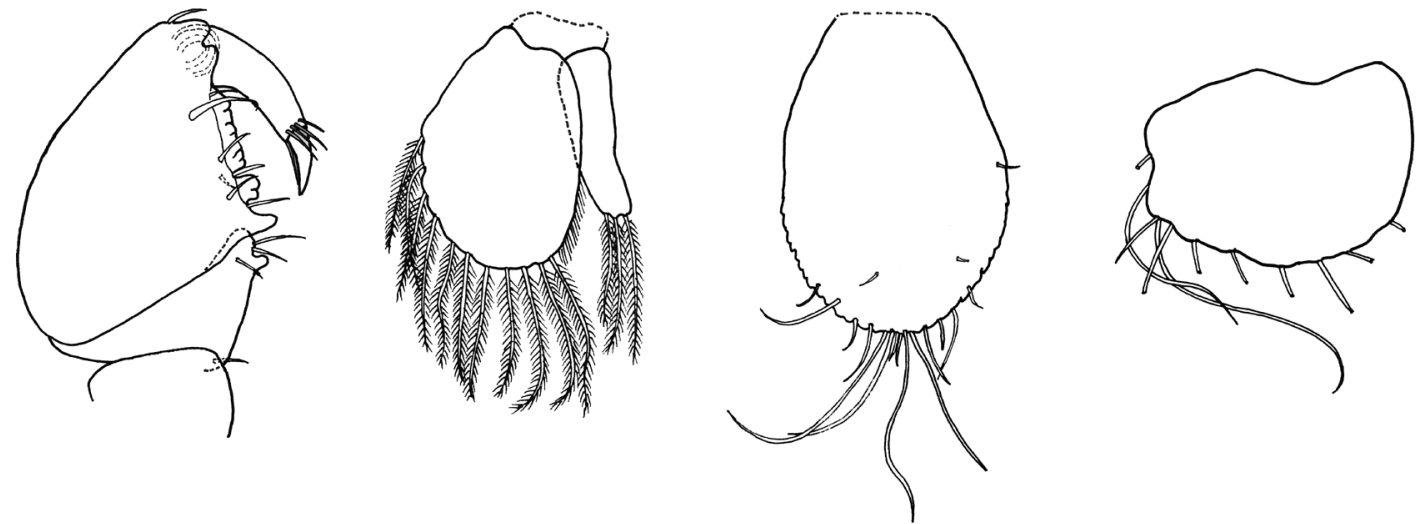

Madang, Papua New Guinea
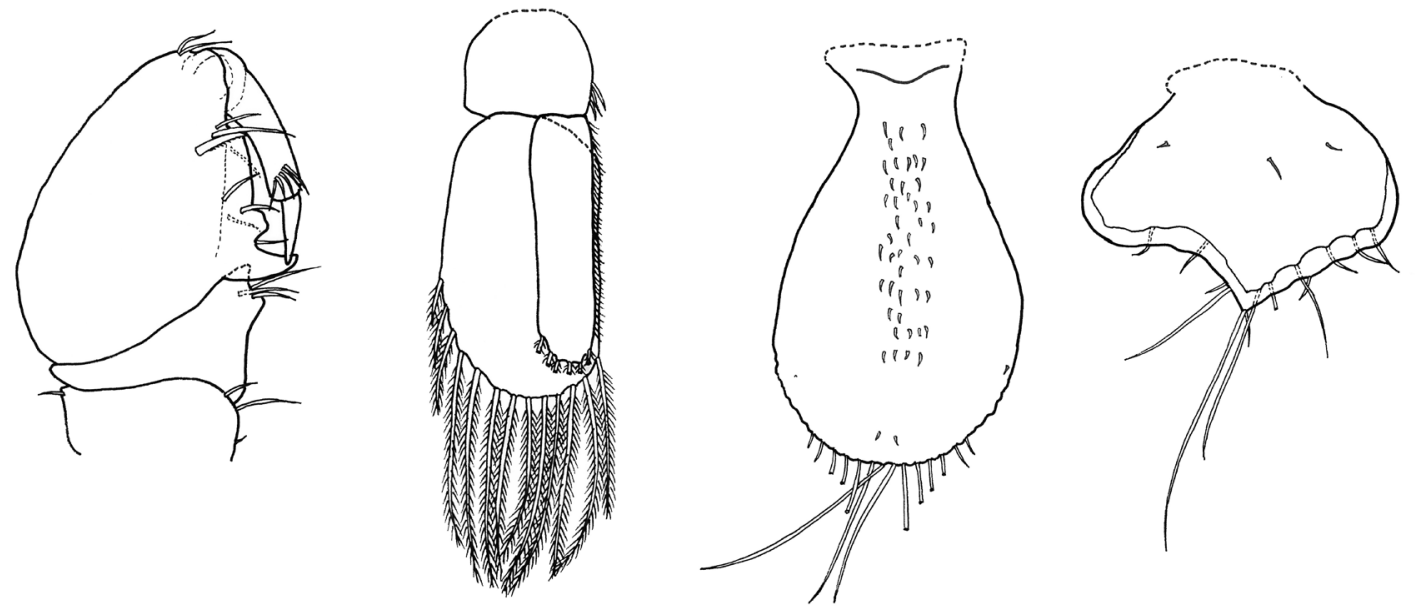

Bangka Island, Indonesia
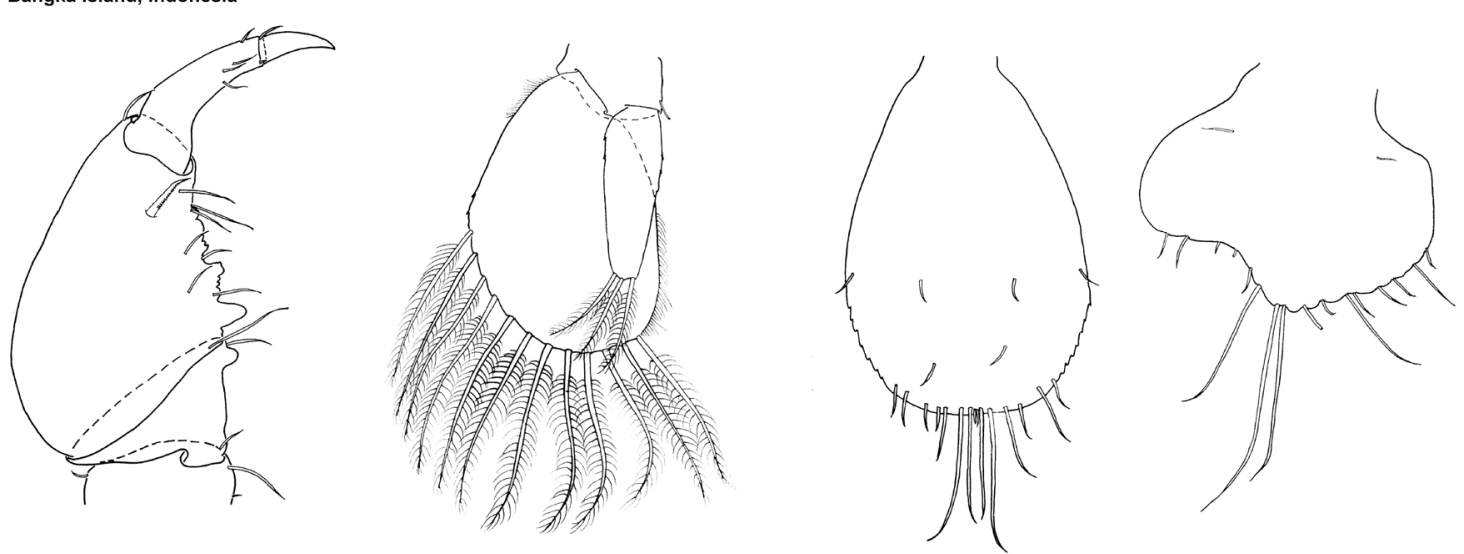

Fig. 23. Expanathura collaris (Kensley, 1979), comparison of published descriptions.pereopod 1, pleopod 1, telson and exopod of uropod. Populations from Fiji (after Negoescu 1999), Madang (after Negoescu and Brandt 2001) and Bangka Island (present publication). 


\section{Remarks}

Most characters useful to distinguish the species can be found in the shape of the palm of pereopod 1 , pleopod 1 endopod, the uropod exopod, and the telson. The pereopod 1 palm generally has a proximal protrusion and often irregular crenulations on the upper half.

The species Expanathura amstelodami (Kensley, 1976) from Amsterdam Island and Madagaskar, E. ardea Poore \& Kensley, 1981 from Queensland and E. mooreae Müller, 1993 from Moorea all have a pleopod 1 with a small, narrow endopod. In addition, these species have a lanceolate uropod exopod and a pereopod 1 propodus palm that lacks crenulations on its distal half. We call these species the amstelodami group.

Our material from Bangka Island is more similar to E. collaris (Kensley, 1979), originally described from Fiji and Rarotonga, E. haddae Kensley \& Poore, 1982 from Houtman Abrolhos Islands, and E. macronesia (Kensley, 1980) from Réunion, near Mauritius, and according to Kensley (1988) also found in the Aldabra Atoll. In these three species (the collaris-group) the uropod exopod is more rounded, with a concavity of the distal outer margin.

Our material from North Sulawesi clearly belongs to the collaris group and resembles most E. collaris as described by Kensley (1979). However, a difference is the shape of pleopod 1 endopod, which in Kensley's material is wider and bears distally 8 swimming setae, while in our material pleopod 1 endopod is distally narrow, and the number of setae can vary from 2-5 (see Fig. 21). Expanathura haddae has been described with a flattened telson apex (Kensley \& Poore 1982), less rounded than in E. collaris. Expanathura macronesia Kensley, 1980 has in the original description a P1 palm without crenulations on its distal half, however, these are present in Müller's redescription (Müller 1990). The proximal projection on the $\mathrm{P} 1$ palm is curved and more pointed than in the Bangka-Island material and the distal outer setae on $\mathrm{P} 7$ propodus are not trifurcate.

There are 6 publications with descriptions of Expanathura collaris from different places, with astonishing variations between populations (see Figs 22-23). Some of these differences can be attributed to the style and detail of illustrations, however, conspicuous differences in pereopod 1, uropod exopod shapes and of the endopod of pleopod 1 suggest that there is more than one species involved.

The material described by Chew et al. (2018) from Malaysia has a similar telson setation as the Bangka material, a uropod exopod with shorter setae, but further details are undescribed. Expanathura collaris as described by Negoescu \& Brandt (2001) from Madang (Papua New Guinea) looks more like E. macronesia Kensley (1980, from the Madagaskar region); these animals have an acute and curved proximal projection on the propodus palm of pereopod 1 and a more acute point before the concave region of the uropod exopod margin. We propose to exclude this material from the species E. collaris s. str. Specimens from Fiji described by Negoescu (1999) share with our Bangka material the narrow pleopod 1 endopod with 3 distal swimming setae, however, the uropod exopod has a very different shape; the concave part of the outer margin is small and the exopod has a more rounded shape clearly different from Kensley's original description. Specimens from Queensland described by Poore \& Lew Ton (2002) have a pereopod 1 propodus palm with no crenulations on its upper half, the proximal protrusion is very small. This could also be a hitherto undescribed species. Specimens described by Müller (1993) also seem to lack the crenulation on the P1 propodus palm and there are no setae on the concave part of the uropod exopod margin.

For a better understanding of this species group new descriptions of material from several localities are needed. DNA data could help to clarify species delimitations. 


\section{Expanathura marcoi sp. nov. urn:lsid:zoobank.org:act:DFACB325-7630-4AD8-8D79-DF56703533F5}

Figs 24-26

\section{Differential diagnosis}

Expanathura with small eyes, remarkably large plumose setae on both antennae, subchelate pereopds 1-3; pereopod 1 propodus palm nearly straight, not crenulated and proximally without protrusion; pereopod 2 propodus palm proximally with 1 small protrusion, distal half of edge irregularly crenulated; merus and carpus posterior margin emarginated, pereopod 3 propodus palm proximally with 2 protrusions, exopod of uropod rounded, not lanceolate, margin distal half with concavity, with acute point in center before concave region.

Expanathura of the collaris group, differing from other species at first sight in the shape of the pereopod 1 propodus palm that has no proximal protrusion and crenulation. This is unique among this species group. Furthermore, the species has remarkably large plumose setae of the antennae. The protruding edge of peduncle article 2 of antenna 2 has been illustrated also for E. ardea, E. collaris sensu Müller (1993) and E. macronesia. Unfortunately, for several species of Expanathura the antenna has not been described with sufficient detail to allow a statement on the variation of this character.

\section{Etymology}

The species is dedicated to Marco Segre, owner of the Coral Eye Resort and promoter of coral reef biodiversity research, for enabling Indonesian students to work in his laboratory.

\section{Material examined}

\section{Holotype}

INDONESIA - $q(3.1 \mathrm{~mm})$; Bangka Island, off Coral Eye Resort; $1^{\circ} 44^{\prime} 20.22^{\prime \prime} \mathrm{N}, 125^{\circ} 8^{\prime} 46.07^{\prime \prime} \mathrm{E}$; 1-2 m depth; in coral rubble; M. Annisaqois and J.W. Wägele leg.; Sep. 2019; MZB Iso 108.

\section{Description of holotype}

BoDy. Shape as in previous species.

Antennae. Antenna 1 first article of peduncle 1.4 times as long as wide, with three flagellum articles, on last article one aesthetasc. Antenna 2 peduncle second article distally with distinct protrusion; with 3 short flagellar articles. Remarkably large plumose setae on both antennae.

MANDible PALP. With 3 articles, last article bearing 4 short setae. Mandibular endite without molar process, serrated lamina dentata, pars incisiva with two notches. Maxilla 1 distally with 1 big and 3 small spine-like teeth. Maxilliped with 5 articles, last article tiny, stout endite reaching half of palp article 3, distally two short setae; laterally on third palp article a thick, laterally finely serrated seta. Pereopods 1-3 subchelate.

PEREOPODS. Pereopod 1 propodus palm nearly straight, not crenulated and proximally without protrusion; pereopod 2 propodus palm proximally with 1 small protrusion, distal half of edge irregularly crenulated; merus and carpus posterior margin emarginated. Pereopod 3 propodus palm proximally with 2 protrusions on lower half, merus and carpus posterior margin emarginated. Pereopods 4-7 subsimilar, two sensory spines on propodus palm of P4-6, only 1 on $\mathrm{P} 7$. 

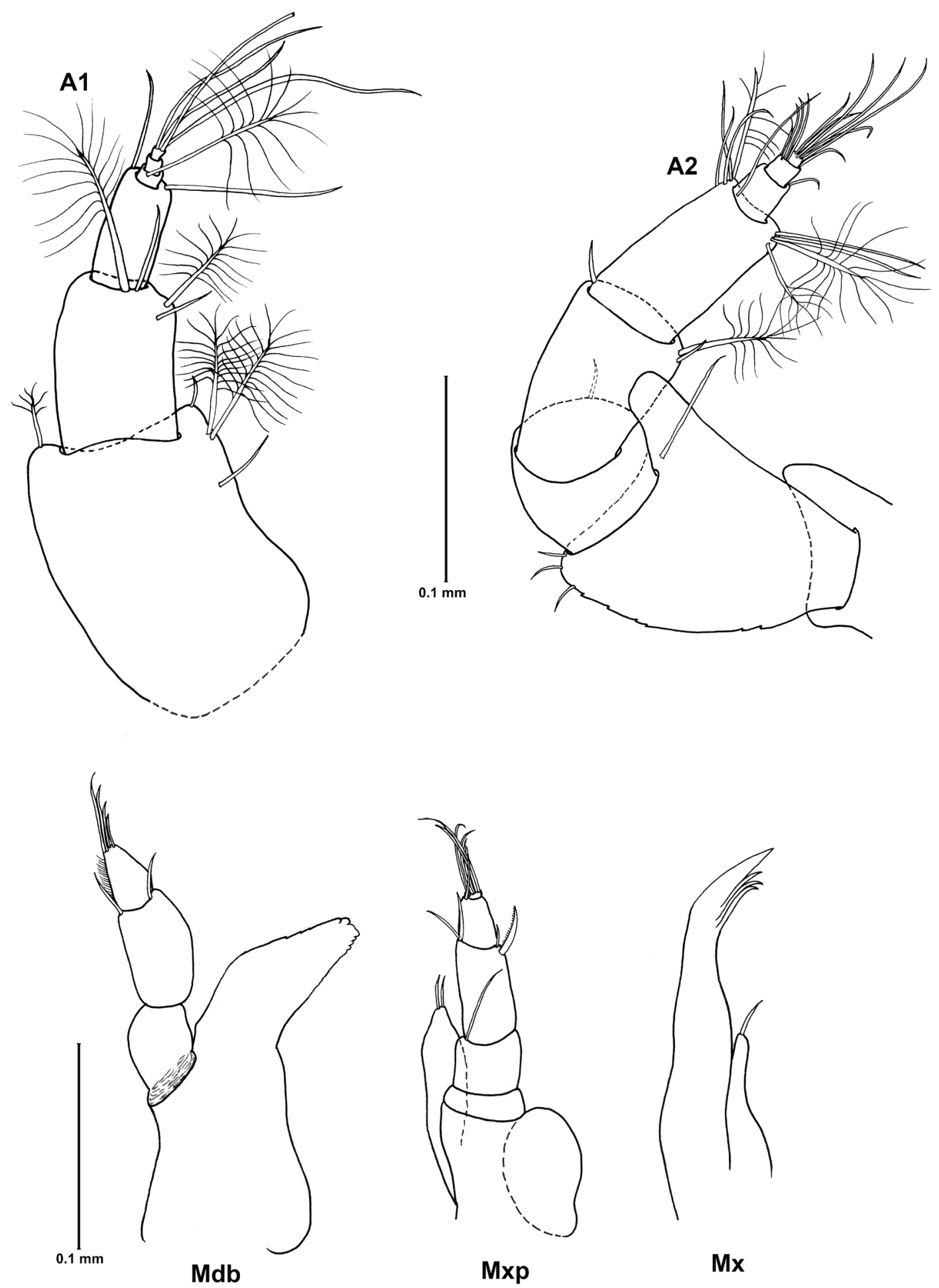

Fig. 24. Expanathura marcoi sp. nov., holotype, + $(3.1 \mathrm{~mm})$ (MZB Iso 108). Abbreviations: A1 = antenna $1 ; \mathrm{A} 2=$ antenna $2 ; \mathrm{Md}=$ mandible; $\mathrm{Mx}=$ maxilla; $\mathrm{Mxp}=$ maxilliped. 


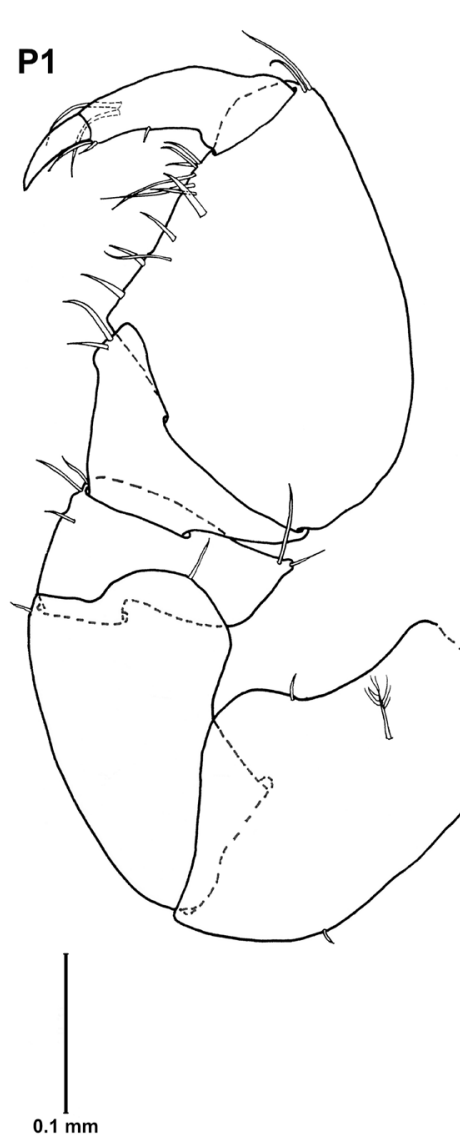

P2
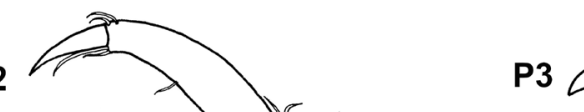

P4
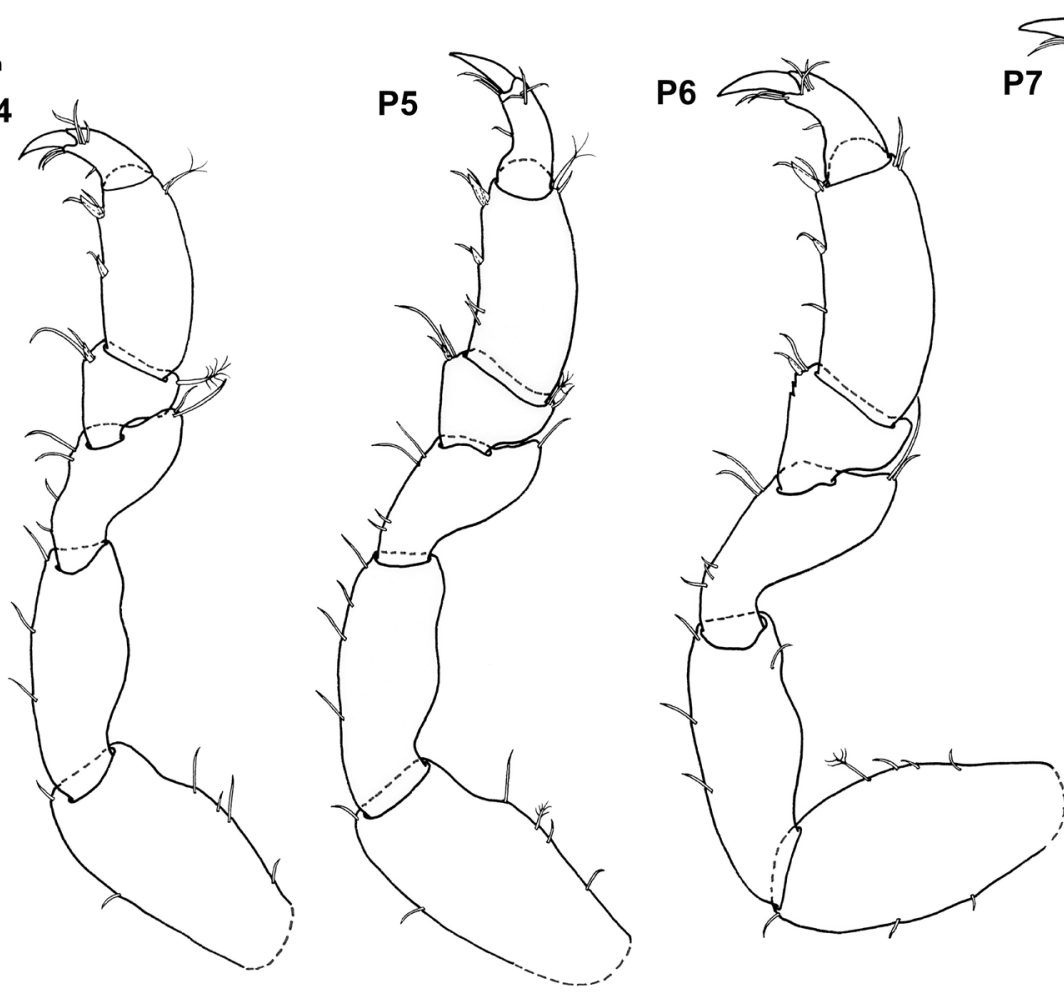

P7

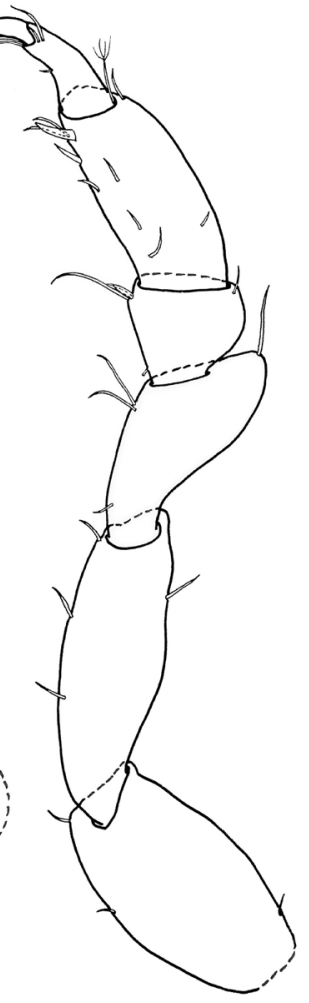

Fig. 25. Expanathura marcoi sp. nov.,, , holotype (MZB Iso 108). Abbreviations: $\mathrm{P} 1-\mathrm{P} 7=$ pereopods 1-7. 
Pleopods. Pleopod 1 exopod broad oval, with 17 feathered setae, endopod shorter and much narrower than exopod, distally as wide as proximally, with 5 feathered setae on distal margin. Exopod of uropod margin distal half with concavity, with acute point in center before concave region.

TeLson. Broad, tongue-shaped, with rounded apex, at broadest part with a pair of short lateral setae, 5 pairs of setae on distal margin.
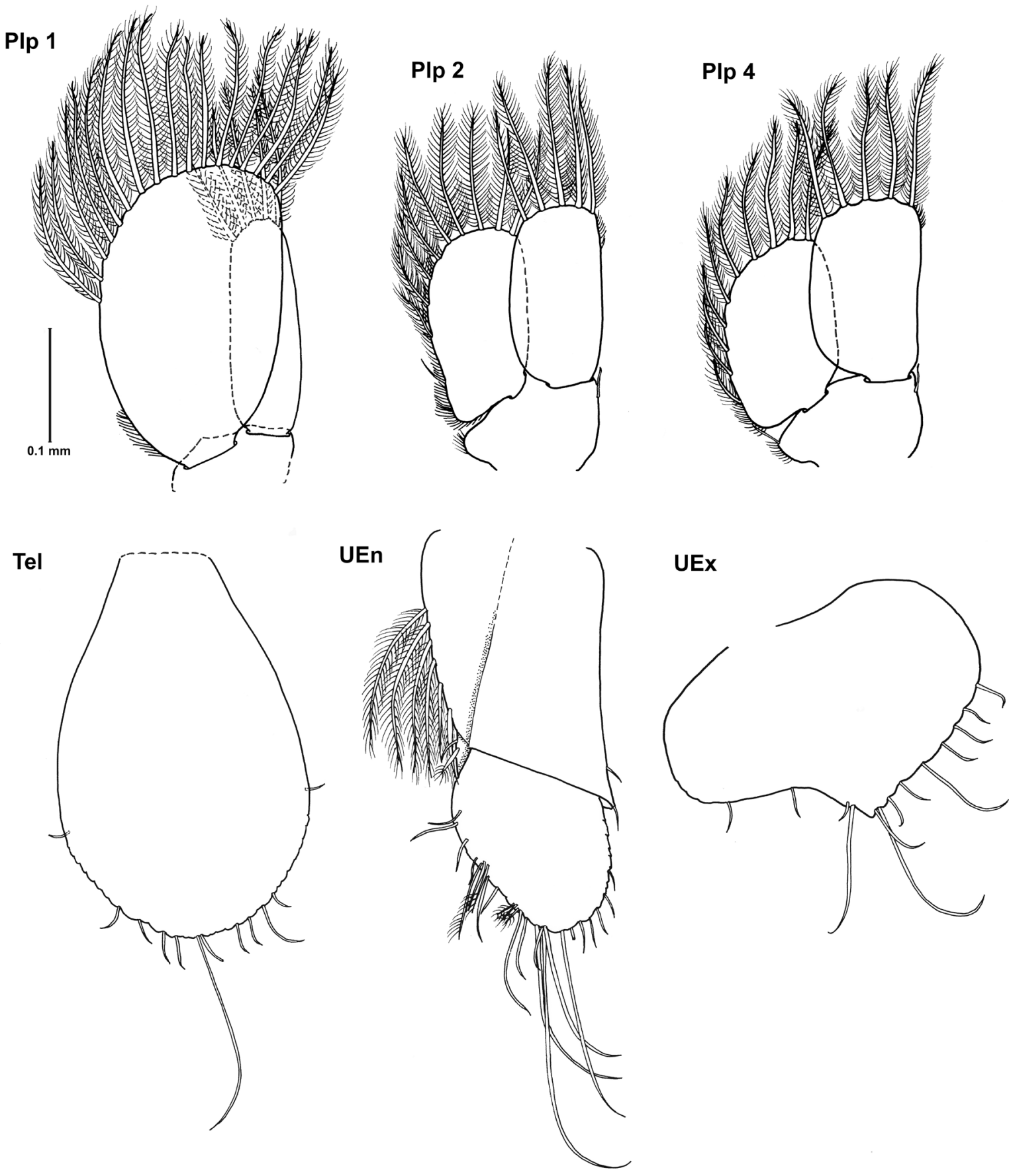

Fig. 26. Expanathura marcoi sp. nov.,, , holotype (MZB Iso 108). Abbreviations: Plp1-Plp4 = pleopods $1-4 ; \mathrm{UEx}=$ exopod of uropod; UEn = endopod of uropod; Tel = telson. 


\section{Remarks}

A remarkable detail of E. marcoi sp. nov. is the tooth-like protrusion on the second article of antenna 2. Such a protrusion has only been described before from E. collaris. The latter species has on the pereopod 1 propodus palm a large basal tooth and more distally another tooth and small crenulations, while in E. marcoi sp. nov. the propdus palm is straight, a unique feature in this genus.

\section{Family Paranthuridae Menzies \& Glynn, 1968}

Genus Colanthura Richardson, 1902

\section{Type species}

Colanthura tenuis Richardson, 1902. Ten species are currently accepted in this genus. Most have been found in shallow habitats of the Indo-Pacific; however, C. uncinata Kensley, 1978 has been found at a depth of 775 m off South Africa (Kensley 1978b).

Colanthura gerungi sp. nov.

urn:lsid:zoobank.org:act:1F397C5C-DDE1-440D-9B96-9B181CECA23D

Figs $27-35$

\section{Differential diagnosis}

Species of Colanthura with expanded propodus of subchelate pereopod 1, palm with proximal triangular tubercle protruding at posterior margin; mesial surface beside this tubercle with row of 18 setae, propodus of subchelate pereopods $2-3$ oval, 2 times long than wide, pereopod 2 with row of 5 medial sensory spines on propodus palm, six such spines on P3; uropod endopod ovate, about 0.8 times sympod length, exopod shorter and roughly triangular, margins of endopod, exopod and tip of telson weakly crenulated; telson tongue-shaped, rounded distal margin bearing 5 pairs of long setae, 2 pairs of short setae dorsomedially near apex, and 4 further pairs of dorsal setae near lateral margin.

Colanthura kensleyi Poore, 1984 from the Philippine and Sangihe Islands (north of the Sulawesi area sampled for this study) shows close affinities to the material from Bangka Island described herein; both species are best distinguished through the uropod exopod, which is triangular to oval in C. gerungi sp. nov., while in $C$. kensleyi the uropod exopod has an elongate oval shape. Also, the propodus of pereopod 1 is wider in C. kensleyi, and lacks additional mesial setae distally. Three of these are present parallel to the palm of the female in our material. A redescription of $C$. kensleyi is needed for further comparison (see also Poore 1984).

\section{Etymology}

This species is dedicated to Dr Grevo Gerung, who sponsored and supervised the studies of the first author.

\section{Material examined}

\section{Holotype}

INDONESIA - $\sigma^{\wedge}(3.8 \mathrm{~mm})$; Bangka Island, west of Coral Eye Resort; $1^{\circ} 45^{\prime} 20.77^{\prime \prime} \mathrm{N}, 125^{\circ} 7^{\prime} 57.28^{\prime \prime} \mathrm{E}$; 1-2 m depth; in seagrass bed; M. Annisaqois and J.W. Wägele leg.; Sep. 2019; MZB Iso 109.

\section{Allotype}

INDONESIA • + (3.9 mm); Bangka Island, west of Coral Eye Resort; 1'45'19.92" N, 1257'58.96" E; 1-2 m depth; on mangrove roots; M. Annisaqois and J.W. Wägele leg.; Sep. 2019; MZB Iso 110. 


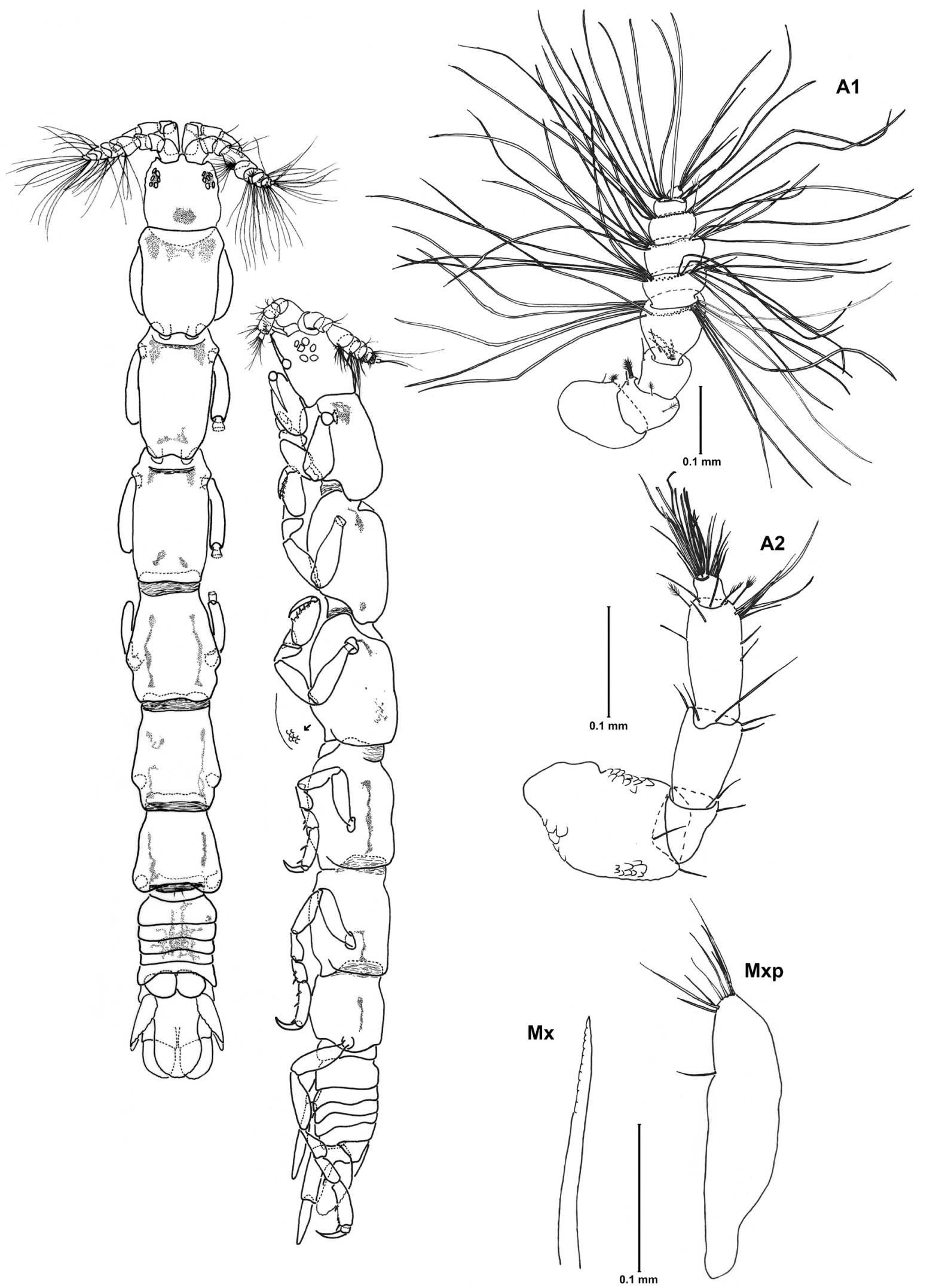

Fig. 27. Colanthura gerungi sp. nov., $\widehat{\jmath}$, holotype (3.8 mm), in dorsal and lateral view (MZB Iso 109). Abbreviations: $\mathrm{A} 1=$ antenna $1 ; \mathrm{A} 2=$ antenna $2 ; \mathrm{Mx}=$ maxilla; $\mathrm{Mxp}=$ maxilliped. 

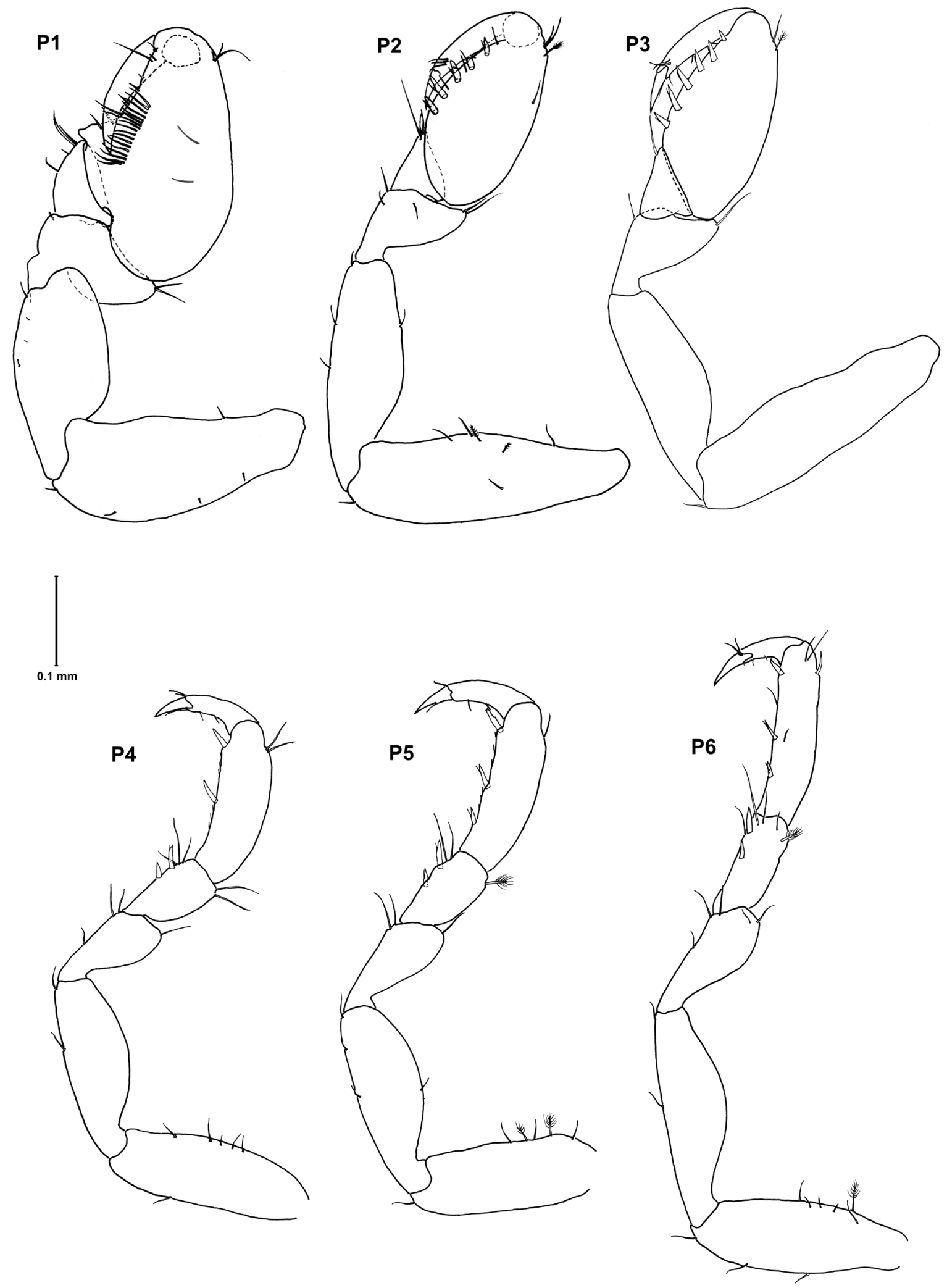

Fig. 28. Colanthura gerungi sp. nov., Ô, holotype (MZB Iso 109). Abbreviation: P1-P6 = pereopods 1-6. 

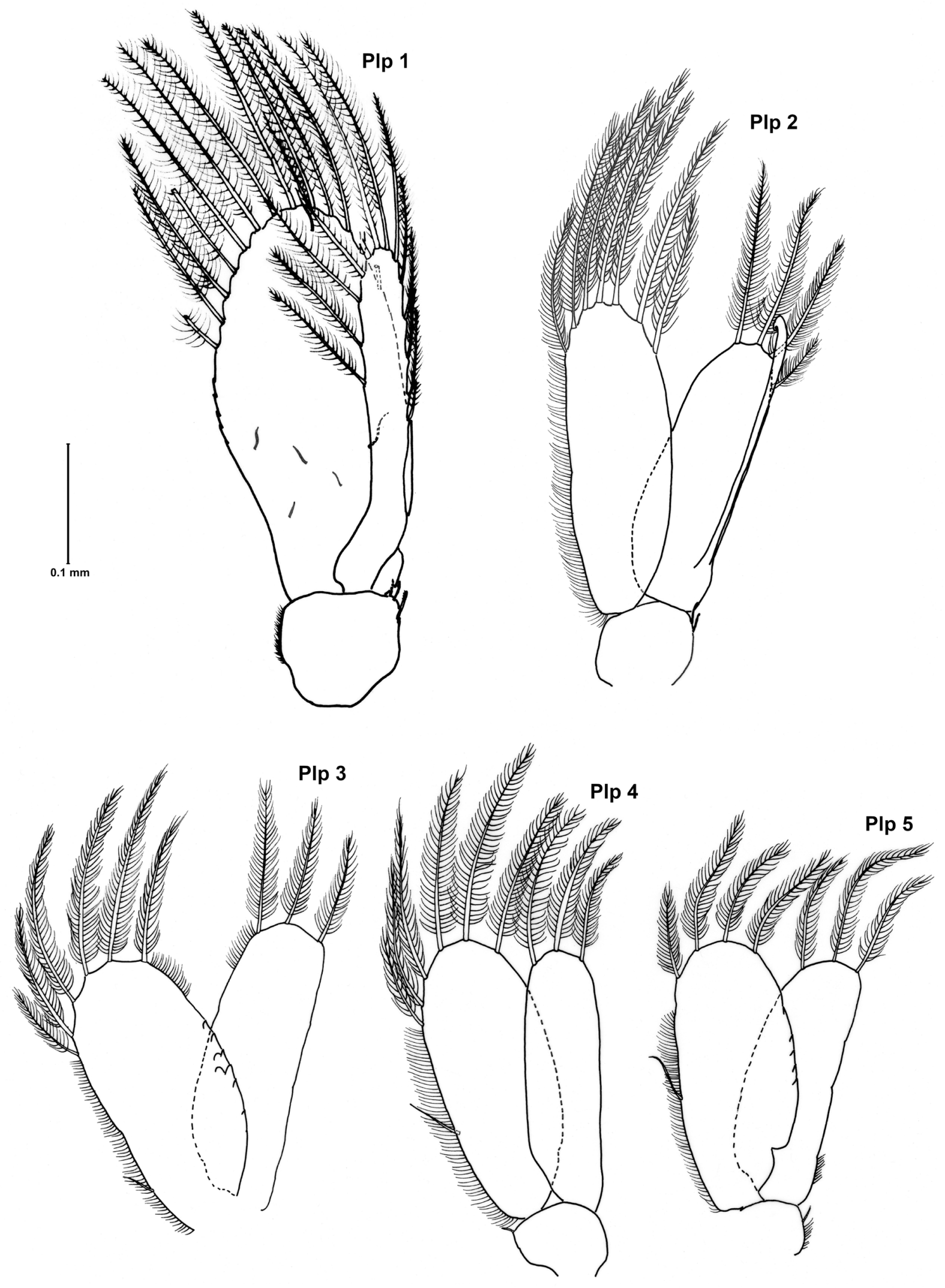

Fig. 29. Colanthura gerungi sp. nov., $\widehat{\jmath}$, holotype (MZB Iso 109). Abbreviation: Plp1-Plp5 = pleopods 1-5. 
Paratypes

INDONESIA $\bullet 1 \hat{\partial}(3.5 \mathrm{~mm}), 1$ क $(3.7 \mathrm{~mm}), 11$ immature specimens $(1.6-3.9 \mathrm{~mm})$; Bangka Island; $1^{\circ} 45^{\prime} 20.77^{\prime \prime} \mathrm{N}, 125^{\circ} 7^{\prime} 57.28^{\prime \prime} \mathrm{E}$; $1-2 \mathrm{~m}$ depth; in seagrass bed; M. Annisaqois and J.W. Wägele leg.; Sep. 2019; MZB Iso 111 • 1 immature specimen; Bangka Island; $1^{\circ} 45^{\prime} 19.92^{\prime \prime} \mathrm{N}, 1^{\circ} 5^{\circ} 7^{\prime} 58.96^{\prime \prime} \mathrm{E}$; $1 \mathrm{~m}$ depth; on mangrove roots; M. Annisaqois and J.W. Wägele leg.; Sep. 2019; MZB Iso 112 • 1 ; Bangka Island, off Coral Eye Resort; $1^{\circ} 44^{\prime} 22.04^{\prime \prime} \mathrm{N}, 125^{\circ} 8^{\prime} 41.19^{\prime \prime} \mathrm{E}$; $1-2 \mathrm{~m}$ depth; in coral rubble; M. Annisaqois and J.W. Wägele leg.; Sep. 2019; MZB Iso 113.

\section{Description}

\section{Male}

BoDy. Slender, about 13 times as long as greatest width, dorsally weakly pigmented, scattered small cuticular scales on body and part of appendages. Cephalothorax in dorsal view roughly as long as wide, pair of compound eyes with few but distinct ommatidia. Body proportions: $\mathrm{C}<1<2=3>4>5>6>>7$. Pereonite 7 is strongly reduced, without appendages, not as long as pleonite 3 or 4 . Pleonites $1-5$ free, together length about as pereonite 6 .

Antennae. Antenna 1 with 6 flagellar articles, articles broader than long, many long aesthetascs surround flagellar segments, on last article 4 aesthetascs. Antenna 2 with short flagellum, basal flagellar article slightly as long as wide, followed by 3 minute articles. Mandible fused laterally to cephalothorax (see

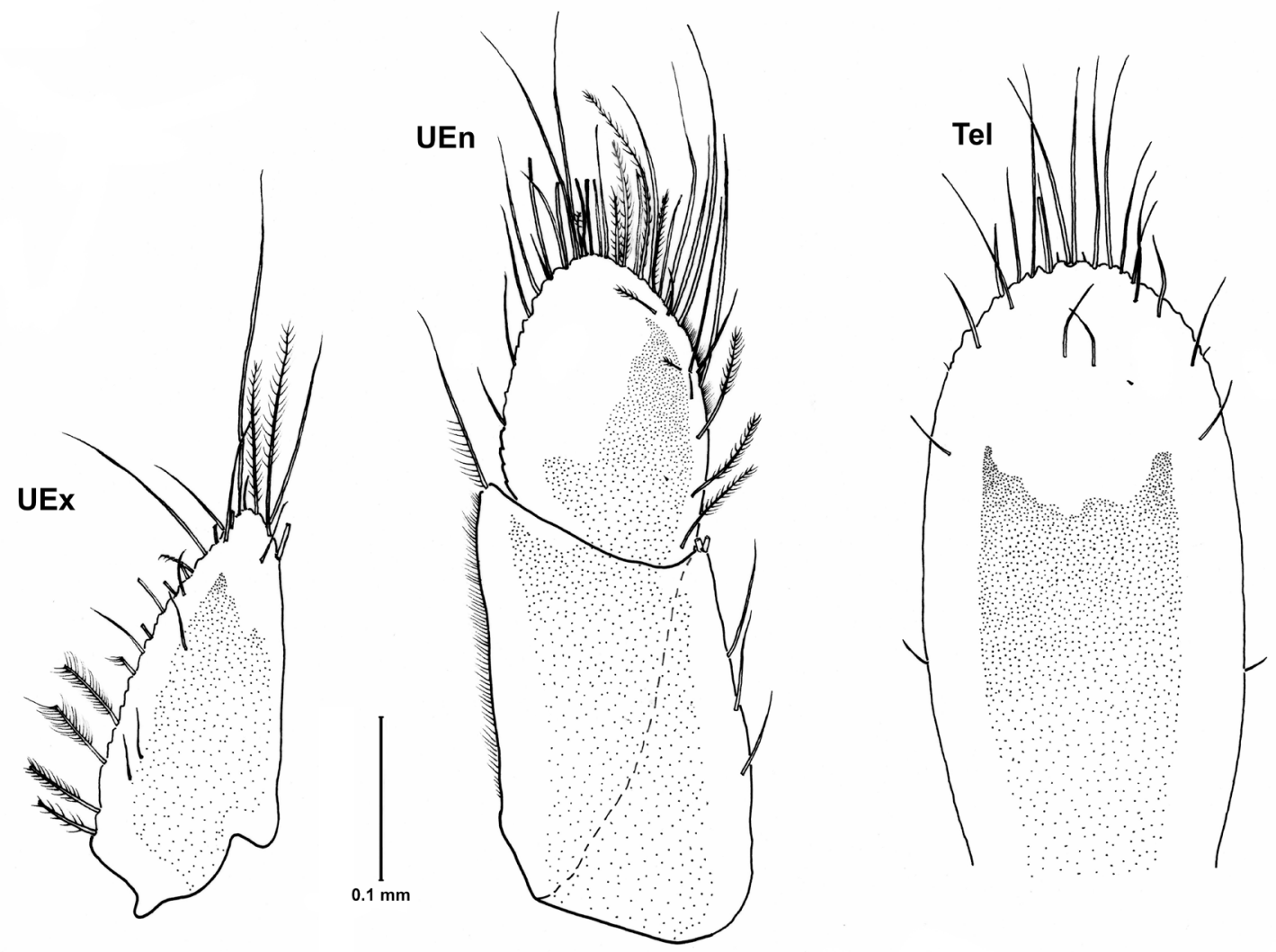

Fig. 30. Colanthura gerungi sp. nov., Ô, holotype (MZB Iso 109). Abbreviations: UEx $=$ exopod of uropod; UEn = endopod of uropod; Tel = telson. 


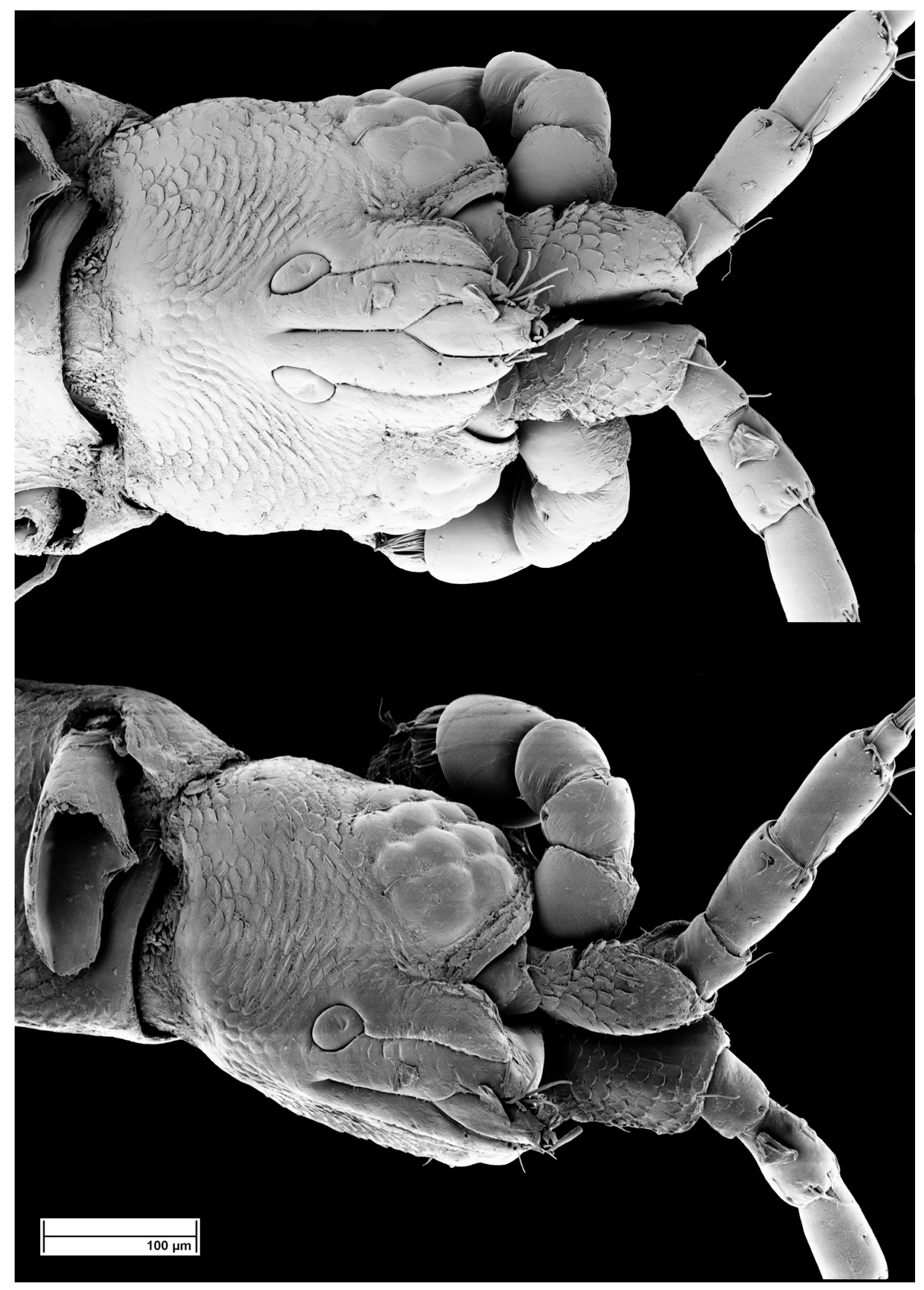

Fig. 31. Colanthura gerungi sp. nov., SEM-images of a male specimen. Cephalothorax in ventral and lateral view. The maxillipeds are flanked laterally by mandibles which are fused to the cephalothorax. This explains why mandibles are usually missing among dissected mouthparts of this genus. The part distally in between maxillipeds is the hypopharynx, which envelopes the maxillae and distal parts of the mandibles. Note the bulging lenses of lateral eyes. 


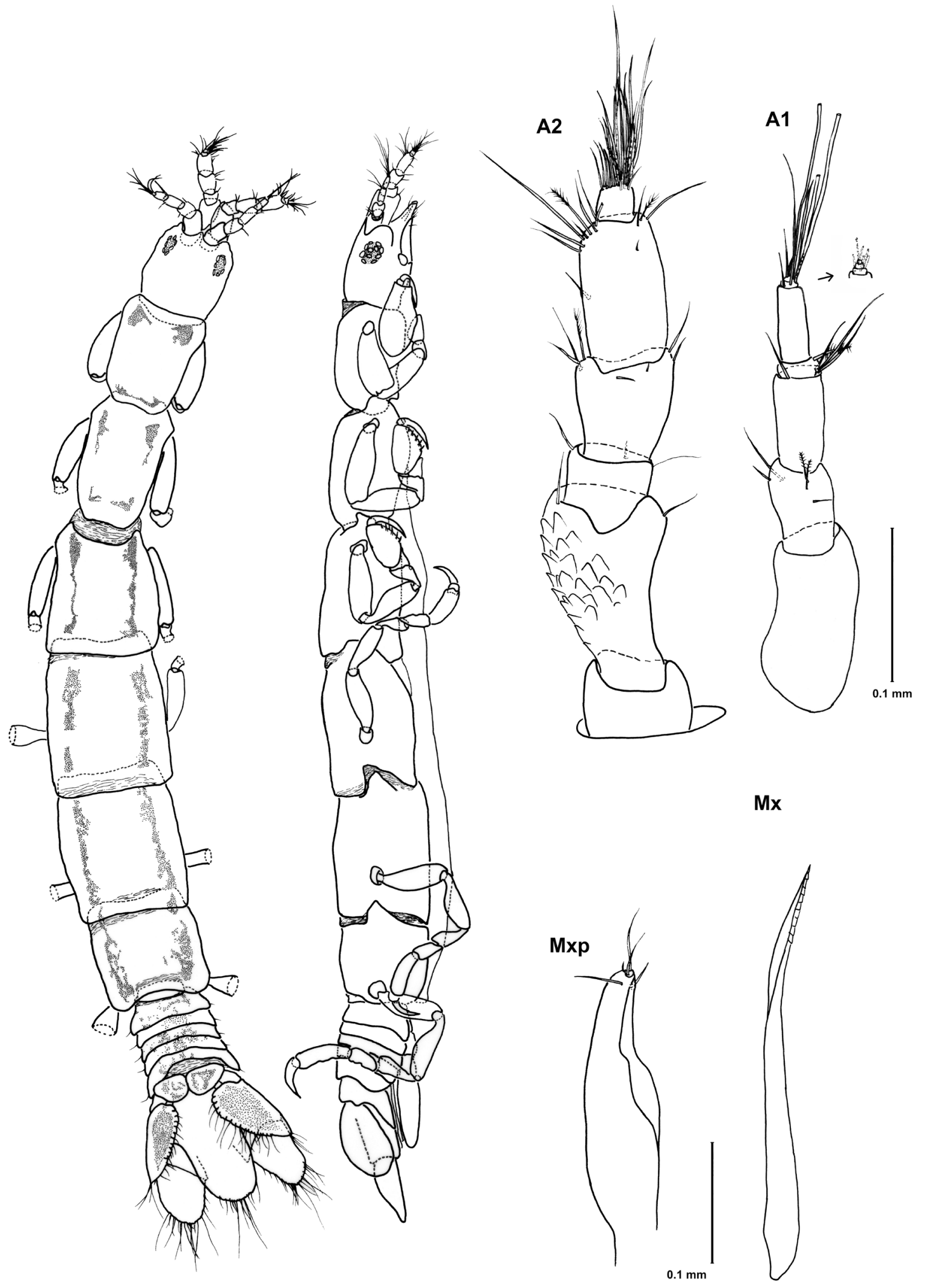

Fig. 32. Colanthura gerungi sp. nov.,, , allotype in dorsal and ventrolateral view ( $3.9 \mathrm{~mm})$ (MZB Iso 110). Abbreviations: $\mathrm{A} 1=$ antenna $1 ; \mathrm{A} 2=$ antenna $2 ; \mathrm{Mx}=$ maxilla; $\mathrm{Mxp}=$ maxilliped. 

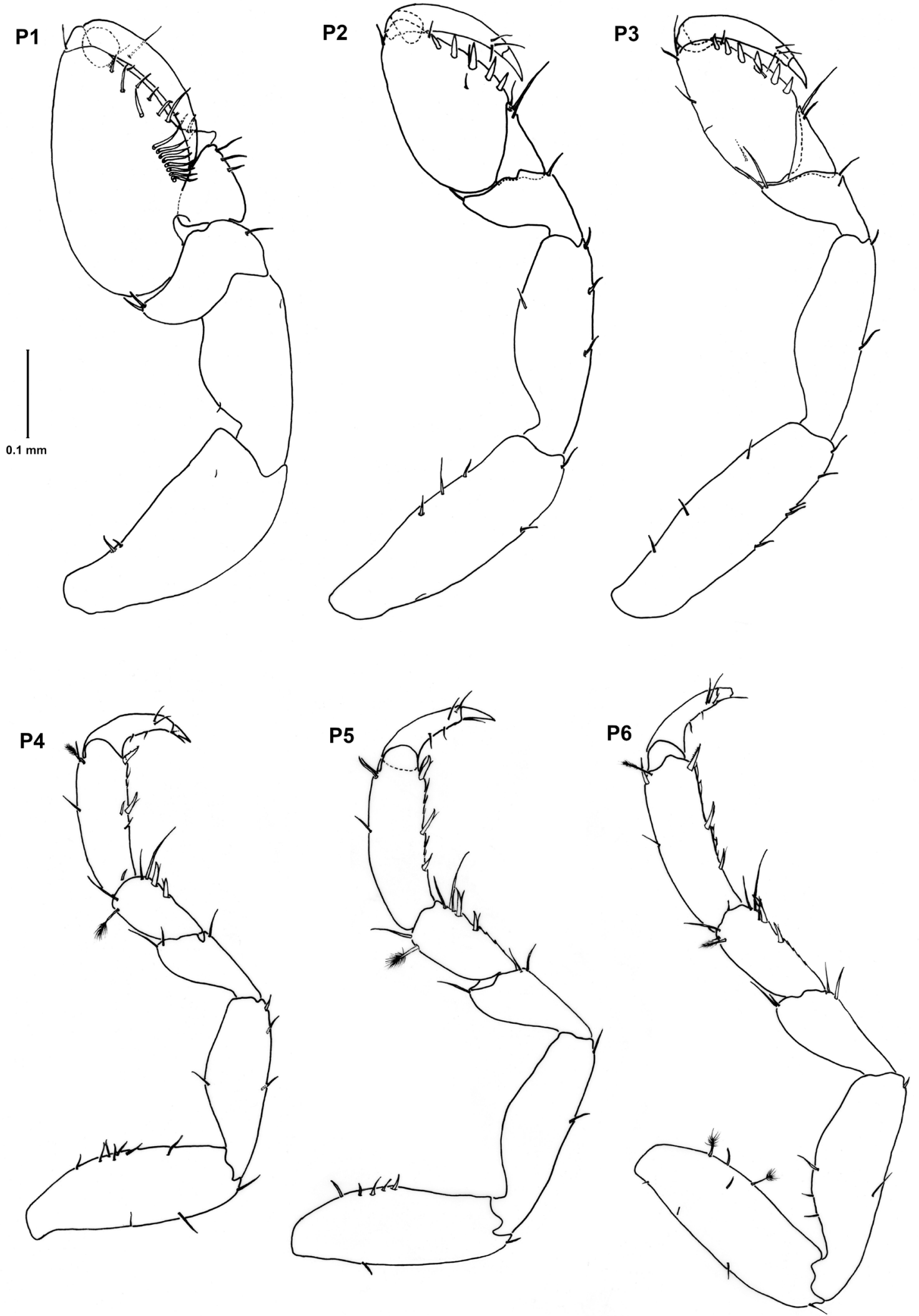

Fig. 33. Colanthura gerungi sp. nov., + , allotype (MZB Iso 110). Abbreviation: P1-P6 = pereopods $1-6$. 
Fig. 31), palp and molar absent. Maxilla 1 slender lanceolate, apex laterally serrated, with 11 saw-teeth. Maxilliped uniarticulate without sutures separating articles, bearing 9 simple setae, 8 of them near apex.

Pereopods. Pereopods 1-3 subchelate. Expanded propodus of pereopod 1 with proximal triangular tubercle protruding at posterior margin; mesial surface beside this tubercle with row of 18 setae and further setae on palm. Propodus of pereopods 2-3 oval, 2 times long than wide, dactylus reaching nearly to tip of carpus. Pereopod 2 with row of 5 medial sensory spines on propodus palm, six such spines on P3. Pereopods 4-6 dactylus shorter than propodus, propodus as long as wide and slightly curved, in P6 narrower than in P4 and P5, two sensory spines on palm of P4, three on P5 and P6; carpus lenght as merus, nearly rectangular and as long as wide, with 2 sensory spines on ventral margin, carpus and merus together roughly lenght of ischium.

EXOPODS OF PLEOPOD. Exopod of pleopod 1 operculiform, distal margin with 13 feathered setae, endopod narrower, about $1 / 4$ of exopod width, margin with 13 feathered setae. Exopod of pleopod 2 distally with

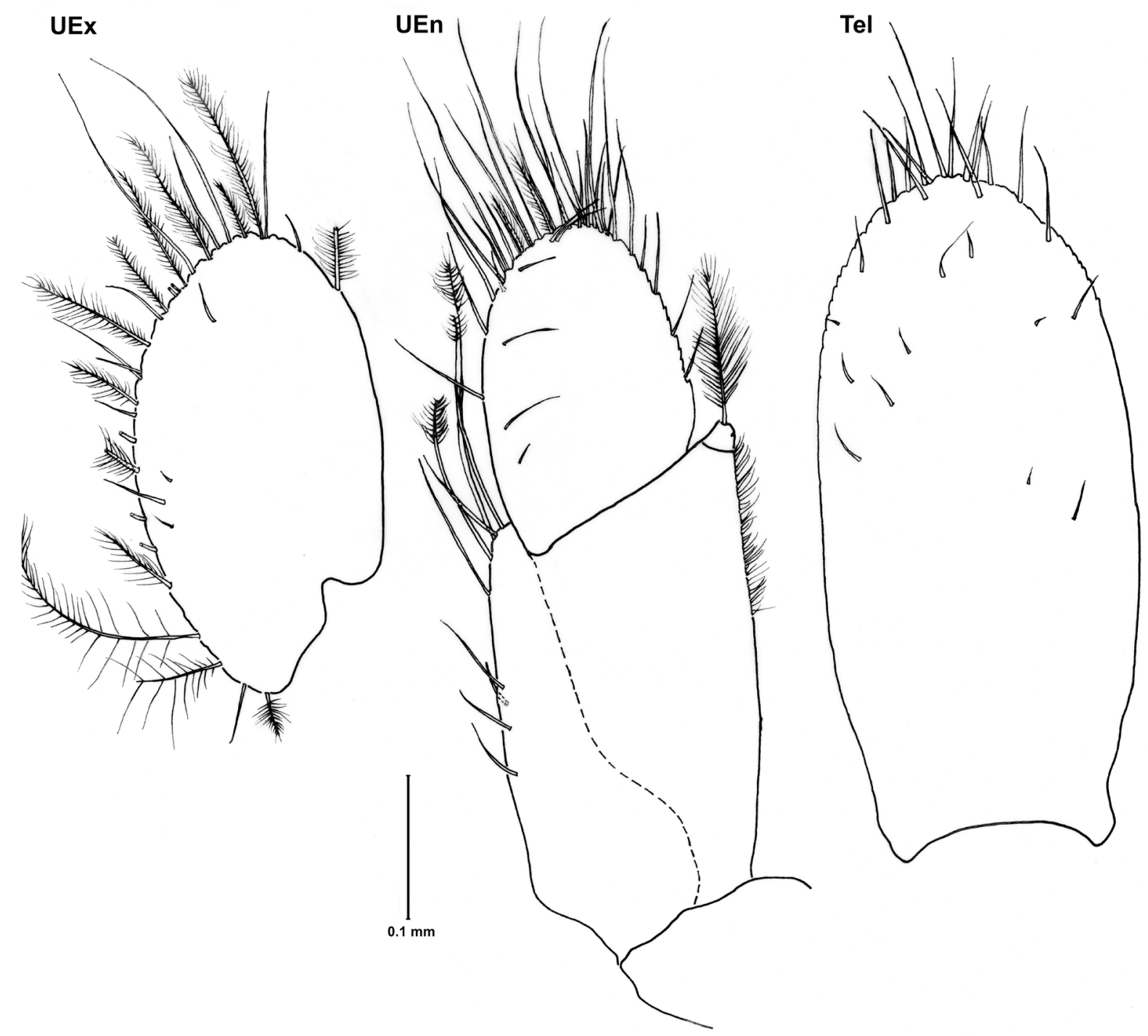

Fig. 34. Colanthura gerungi sp. nov., + , allotype (MZB Iso 110). Abbreviations: UEx $=$ exopod of uropod; UEn = endopod of uropod; Tel = telson. 

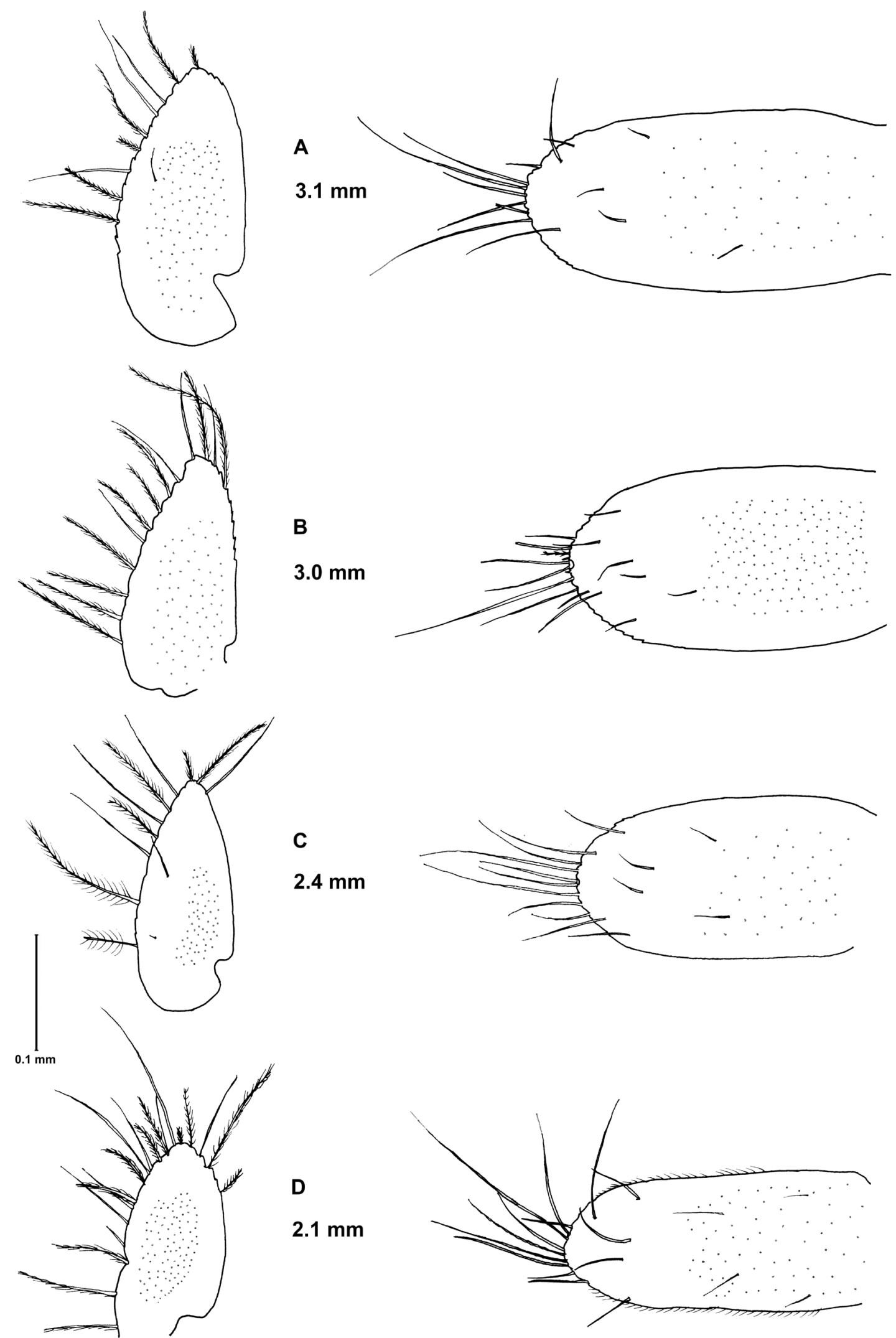

$\mathrm{C}$
$2.4 \mathrm{~mm}$

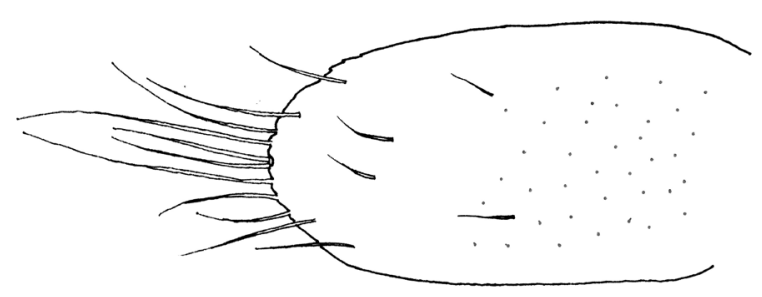

D

$2.1 \mathrm{~mm}$

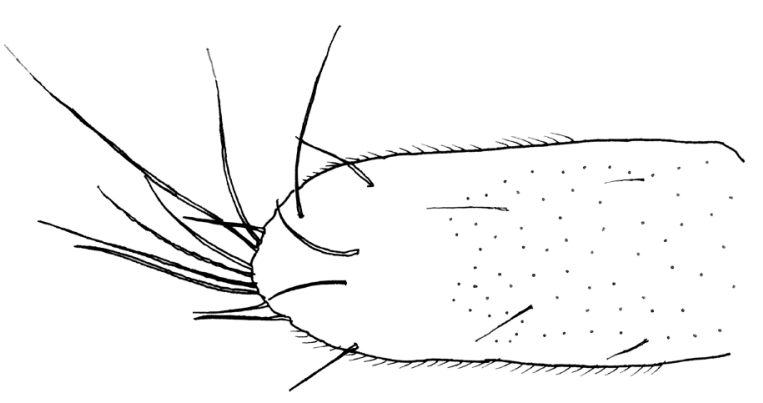

Fig. 35. Colanthura gerungi sp. nov., immature specimens of different sizes (body length in mm). (MZB Iso 111) Comparison of exopods of uropods and telson setations. 
7, endopod with 4 feathered setae. Appendix masculina surpassing tip of endopod, apex with a small hooked knob. Pleopods 3-4 endopod with 3, exopod with 6 distal feathered setae, on pleopod 5 only 5. Uropod endopod ovate, not surpassing telson. Endopod about 0.8 sympod lenght. Exopod of uropod shorter and triangular, with 12 simple setae and 8 feathered setae, most on margin. Margins of endopod, exopod and tip of telson weakly crenulated. Telson tongue-shaped, rounded distal margin bearing 5 pairs of long setae, 2 pairs of short setae dorsomedially near apex, and 4 further pairs of dorsal setae near lateral margin. Setation symmetry is imperfect.

\section{Ovigerous female}

Habitus resembling male (see Fig. 32). Antenna 1 with 4-jointed flagellum; first article of flagellum short, ring-shaped, with 1 feather-like seta; second article longest, distally 2 minute articles; last article with 3 aesthetascs and 4 setae. Antenna 2 flagellum apparently uniarticulate, with whorl of distal setae. Acute mouth parts. Mandible fused laterally to cephalothorax (Fig. 31), without palp and without molar process. Maxilla 1 elongate, acute, distal part serrated with 10 saw-teeth. Maxilliped without sutures separating articles, apically 1 tiny and 4 longer setae. Pereopods $1-3$ subchelate, propodi oval, width about two thirds of length, larger in pereopod 1, dactyli reaching to tip of carpus, carpus triangular. Propodus of pereopod 1 with mesial comb of 8 slender setae near proximal tubercle of palm, more distally three stouter mesial setae and further setae on palm. Palm of propodus of pereopod 2-3 with 5-6 sensory spines. Pereopods 4-6 dactylus shorter than propodus, propodus much as long as wide, slightly curved, with 2 (P4) or 3 (P5-6) sensory spines on palm; carpus dorsally with 1 feather like seta and ventrally 2 sensory spines. Exopod of pleopod 1 operculiform with 13 feathered setae on distal margin, endopod narrow, about $1 / 3$ exopod width, distally with 9 feathered setae. Pleopods $2-5$ endopod with 3 feathered setae and exopod with 8-5 feathered setae. Uropods not surpassing telson, exopod ovate, endopod shorter than sympod (0.6 sympod length) and smaller than exopod. Telson tongue-shaped, rounded distal margin bearing 5 pairs of long setae, 4 pairs of longer dorsal setae, and dorsally many irregularly scattered short setae.

\section{Immature specimens}

In all features quite similar to females. Total length 1.6-3.9 $\mathrm{mm}$. The shape of the uropod exopod varies somewhat, but is in tendency triangular with rounded apex. The setation on the telson is not constant, with pairs of long setae on distal margin and further scattered setae dorsally (see Fig. 35).

\section{Remarks}

This species belongs to the Colanthura group of genera discussed by Poore (1984). The paranthurid genera Califanthura Schultz, 1977, Colanthura Richardson, 1902, Cruregens Chilton, 1882 and Cruranthura Thomson, 1946 share the absence of pereopod 7, the short pereonite 7, the fusion of maxilliped basis and palp. Cruregens is blind, Cruranthura has fused pleonites 2-5 and a pereonite 7 that is short but well visible (as in Cruregens). Species of Califanthura and Colanthura are very similar, and it might be that the character distinguishing Colanthura from Califanthura (pleonites not fused in Colanthura) has not always been seen in species assigned to Califanthura and vice versa. Since free pleonites is the plesiomorphic state, Colanthura might be a paraphyletic genus.

Good illustrations of the mandible in these genera are not available. For the Colanthura described herein, we discovered in SEM studies that the mandible is laterally fused to the cephalon and therefore it cannot be dissected with the other mouthparts (see Fig. 31). This fusion might have caused the absence of illustrations of the mandible in descriptions of other species, too. The fusion of the mandible with the head capsule is a unique feature among isopods. It implies that the most active mouthpart is the movable maxilla, which probably is used as a stinging tool in these paranthurids, while mandibles and hypopharynx form a rigid sheath. 
We do not propose to place the genera with fused immobile mandible in a new family. This character evolved within the Paranthuridae, and to separate some genera would leave the remaining ones in a paraphyletic group. This should always be avoided, to prevent the subjective and arbitrary creation of taxa. There are 13 described species with free pleonites that can be assigned to the genus. Unfortunately, several published species descriptions are very incomplete. Most characters useful to distinguish the species can be found in the uropod shape and setation. Species of Colanthura have been found in tropical, temperate, and polar waters. Of the tropical species, Colanthura bruscai Poore, 1984 from Mexico and Costa Rica and Colanthura pigmentata Kensley, 1980 from Madagascar have a broader propodus of pereopod 1 than $C$. gerungi sp. nov. Müller (1993) reported a dorsally black Colanthura tenuis from Bora Bora, where the exopod of the uropod is more elongate than in C. gerungi sp. nov. Müller's species is probably not the same as C. tenuis of Richardson (1902) (redescribed by Poore 1984), which occurs in the western Atlantic Ocean. Colanthura nigra Nunomura, 1975 from Japan is also dorsally black and easily distinguished from other Indo-Pacific species. The uropod sympod is wider than in the specimens described herein. The redescription of C. nigra by Poore (1984) shows a uropod exopod with a distally straight outer margin. Colanthura setouchiensis Nunomura, 1993 from Japan does not have the basal tubercle on the propodus palm of pereopod 1 that is present in most descriptions of Colanthura. Colanthura uncinata Kensley, 1978b from South Africa has a small and narrow uropod exopod with very few setae. The exopod of the uropods of $C$. daguilarensis Bamber, 2000 (a species from Hong Kong) and C. bruscai Poore, 1984 has an outer margin that is distally slightly concave, while in $C$. gerungi sp. nov. the exopod is continuously oval. Colanthura gauguini Müller, 1993 from Moorea has a broad oval uropod exopod with only a few long setae on the distal half of the margin, where other species have in addition feathered setae. The Caribbean species C. ornata Carvacho, 1977 has been described with fused pleonites and might be a Califanthura. Uropod shapes have not been published.

\section{Discussion}

The present study indicates that the diversity of small invertebrates occurring in the Coral Triangle area is still to a large extent undescribed. We only took samples in a small area (Bangka Island region) and already after a first sorting campaign we found more undescribed species than were known until now for the whole Sulawesi region. In the future, sorting more samples will lead to the discovery of many more species. The main difficulty is the separation of these fragile and not abundant species from the sediment and debris. Even gentle washing of samples will destroy several specimens and others stuck in crevices will not be found, wherefore the yield is usually small.

Due to the currently very fragmentary knowledge, it is impossible to predict how many species might occur in specific habitats of the Coral Triangle and what the geographic distribution of single species might be. Currently, this fauna cannot be considered when analyzing human-driven biodiversity changes until species are described. With more material, it will be possible to develop DNA barcodes for these species to enable ecologists to detect their presence.

\section{Acknowledgements}

The authors are grateful to the German Academic Exchange Service (DAAD) for financing the academic cooperation between the partners involved in this study. Special thanks go to Dr Grevo Gerung for supporting the studies of the first author in Manado, to Dr Heike Wägele for getting the DAAD grant and organizing field trips, to Marco Segre, the owner of the Coral Eye Resort, who allowed us to use his facilities, especially his private laboratory, to Dr Markus Lasut for logistic and political support in Manado, to Dr Jane Mamuaja for organizing expedition equipment and helping with supervision of students, to Dr Gustav Mamangkey for helping during a field trip, to Dr Rose Mantiri for helping the first author to complete her masters studies. 


\section{References}

Chew M., Rahim A.A. \& Yusof N.Y. 2018. A new species of Eisothistos (Isopoda, Cymothoida) and first molecular data on six species of Anthuroidea from the Peninsular Malaysia. Zoosystematics and Evolution 94 (1): 73-81. https://doi.org/10.3897/zse.94.23000

Edinger E.N., Kolasa J. \& Risk M.J. 2000. Biogeographic variation in coral species diversity on coral reefs in three regions of Indonesia. Diversity and Distributions 6: 113-127.

Eisenbarth J.H., Undap N., Papu A., Schillo D., Dialao J., Reumschüssel S., Kaligis F., Bara R., Schäberle T.F., König G., Yonow N. \& Wägele H. 2018. Marine Heterobranchia (Gastropoda, Mollusca) in Bunaken National Park, North Sulawesi, Indonesia - A follow-up diversity study. Diversity 10: 1-47. https://doi.org/10.3390/d10040127

Kensley B. 1978. The South African Museum's Meiring Naude Cruises. Part 8. Isopoda Anthuridea. Annals of the South African Museum 77 (1): 1-25.

Kensley B. 1979. New species of anthurideans from the Cook and Fiji Islands (Crustacea: Isopoda: Anthuridea). Proceedings of the Biological Society of Washington 92 (4): 814-836.

Kensley B. 1980. Anthuridean isopod crustaceans from the International Indian Ocean Expedition, 1960-1965, in the Smithsonian Collections. Smithsonian Contributions to Zoology 304: 1-37.

https://doi.org/10.5479/si.00810282.304

Kensley B. 1988. Preliminary observation on the isopod crustacean fauna of Aldabra Atoll. Bulletin of the Biological Society Washington 8: 40-44.

Müller H.G. 1990. Anthuridea from coral reefs at Reunion Island, southern Indian Ocean (Crustacea: Isopoda). Senckenbergiana Biologica 70: 359-395.

Müller H.G. 1992. Anthuridae from coral reefs at Bora Bora and Moorea, Society Islands, with description of three new species (Crustacea: Isopoda). Senckenbergiana Biologica 72: 353-371.

Müller H.G. 1993. Paranthurid isopods from French Polynesian coral reefs, including descriptions of six new species (Crustacea: Peracarida). Cahiers de Biologie marine 34 (3): 289-341.

Negoescu I. 1984. The study of the Anthuridean isopods (Crustacea, Isopoda, Anthuridea) from the cruises of the French Oceanographic vessels. Travaux du Muséum d'histoire naturelle "Grigore Antipa" 26: $45-59$

Negoescu I. 1994. Isopoda Anthuridea (Crustacea: Pericarida) from New Caledonia and Loyalty Islands (South-western Pacific Ocean), I. Travaux du Muséum d'histoire naturelle "Grigore Antipa" 34: 147225.

Negoescu I. 1997. Isopoda Anthuridea. Results of the Zoological Expedition organized by "Grigore Antipa" Museum in the Indonesia Archipelago (1991). 1. Peracarida (Crustacea). Travaux du Muséum national d'histoire naturelle "Grigore Antipa" 38: 177-251.

Negoescu I. 1999. Isopoda Anthuridea (Crustacea) from Fiji Islands. Three new species, first record of primary and secondary males in Paranthuridae family. Travaux du Muséum national d'histoire naturelle "Grigore Antipa" 41: 199-280.

Negoescu I. \& Wägele J.W. 1984. World list of the anthuridea isopods (Crustacea,Isopoda,Anthuridea). Travaux du Muséum d'histoire naturelle "Grigore Antipa” 25: 99-146.

Negoescu I. \& Brandt A. 2001. Apanthura monodi sp. nov. and Apanthura forceps sp. nov. (Isopoda: Anthuridea) from the southwest Pacific Ocean, Papua New Guinea and redescription of two species. Mitteilungen aus dem Hamburgischen Zoologischen Museum und Institut 98: 99-130. 
Pasternak B. 1982. Composition, origin and peculiarities of distribution of the Mediterranean deep-sea isopod fauna. Trudy Instituta Okeanologii Akademiya Nauk SSR 117: 163-177.

Poore G.C.B. 1984. Colanthura, Califanthura, Cruranthura and Cruregens, related genera of the Paranthuridae (Crustacea: Isopoda). Journal of Natural History 18: 697-715.

Poore G.C.B. 2001. Families and genera of Isopoda Anthuridea. Crustacean Issues 13: 63-173

Poore G.C.B. \& Lew Ton H.M. 1988. A generic review of the Hyssuridae (Crustacea: Isopoda) with a new genus and new species from Australia. Memoirs of the Museum of Victoria 49 (1): 169-193.

Poore G.C.B. \& Lew Ton H.M. 2002. Expanathuridae (Crustacea: Isopoda) from the Australian region. Zootaxa 82: 1-60. https://doi.org/10.11646/zootaxa.82.1.1

Richardson H. 1902. The marine and terrestrial isopods of the Bermudas, with descriptions of new genera and species. Transactions of the Connecticut Academy of Sciences 11: 277-310.

Sidabalok C.M. 2013. List of marine isopods recorded from Indonesian waters. Marine Research in Indonesia 8:49-66.

Wägele J.W. 1981a. Study of the Hyssuridae (Crustacea: Isopoda: Anthuridea) from the Mediterranean and the Red Sea. Israel Journal of Zoology 30: 1-2.

Wägele J.W. 1981b. Zur Phylogenie der Anthuridea (Crustacea, Isopoda). Mit Beiträgen zur Lebensweise, Morphologie, Anatomie und Taxonomie. Zoologica Stuttgart 132: 1-127.

Yalindua Y., Peristiwady T. \& Ibrahim P.S. 2021. Update on new species and record of fishes in the Coral Triangle region for the last 10 years (2008-2019). Journal of Tropical Biodiversity and Biotechnology 6: 1-12. https://doi.org/10.22146/jtbb.59230

Manuscript received: 22 January 2021

Manuscript accepted: 1 May 2021

Published on: 21 September 2021

Topic editor: Rudy Jocqué

Desk editor: Marianne Salaün

Printed versions of all papers are also deposited in the libraries of the institutes that are members of the EJT consortium: Muséum national d'histoire naturelle, Paris, France; Meise Botanic Garden, Belgium; Royal Museum for Central Africa, Tervuren, Belgium; Royal Belgian Institute of Natural Sciences, Brussels, Belgium; Natural History Museum of Denmark, Copenhagen, Denmark; Naturalis Biodiversity Center, Leiden, the Netherlands; Museo Nacional de Ciencias Naturales-CSIC, Madrid, Spain; Real Jardín Botánico de Madrid CSIC, Spain; Zoological Research Museum Alexander Koenig, Bonn, Germany; National Museum, Prague, Czech Republic. 